\title{
Epidermal Growth Factor Receptor Cell Proliferation Signaling Pathways
}

\author{
Ping Wee and Zhixiang Wang * \\ Department of Medical Genetics and Signal Transduction Research Group, Faculty of Medicine and Dentistry, \\ University of Alberta, Edmonton, AB T6G 2H7, Canada; pwee@ualberta.ca \\ * Correspondence: zhixiang.wang@ualberta.ca; Tel.: +1-780-492-0710 \\ Academic Editor: Samuel C. Mok \\ Received: 7 April 2017; Accepted: 10 May 2017; Published: 17 May 2017
}

\begin{abstract}
The epidermal growth factor receptor (EGFR) is a receptor tyrosine kinase that is commonly upregulated in cancers such as in non-small-cell lung cancer, metastatic colorectal cancer, glioblastoma, head and neck cancer, pancreatic cancer, and breast cancer. Various mechanisms mediate the upregulation of EGFR activity, including common mutations and truncations to its extracellular domain, such as in the EGFRvIII truncations, as well as to its kinase domain, such as the L858R and T790M mutations, or the exon 19 truncation. These EGFR aberrations over-activate downstream pro-oncogenic signaling pathways, including the RAS-RAF-MEK-ERK MAPK and AKT-PI3K-mTOR pathways. These pathways then activate many biological outputs that are beneficial to cancer cell proliferation, including their chronic initiation and progression through the cell cycle. Here, we review the molecular mechanisms that regulate EGFR signal transduction, including the EGFR structure and its mutations, ligand binding and EGFR dimerization, as well as the signaling pathways that lead to G1 cell cycle progression. We focus on the induction of CYCLIN D expression, CDK4/ 6 activation, and the repression of cyclin-dependent kinase inhibitor proteins (CDKi) by EGFR signaling pathways. We also discuss the successes and challenges of EGFR-targeted therapies, and the potential for their use in combination with CDK4/ 6 inhibitors.
\end{abstract}

Keywords: epidermal growth factor receptor; ErBB; signal transduction; ERK; AKT; cell cycle; cell proliferation; G1

\section{Introduction}

Epidermal growth factor (EGF) receptor (EGFR), also known as ErbB1/HER1, is the prototype of the EGFR family that also includes ErbB2/HER2/Neu, ErbB3/HER3, and ErbB4/HER4 [1]. Driven largely by its role in promoting cell proliferation and opposing apoptosis, the EGFR has been vilified as a proto-oncogene. New facts regarding the complex signaling network activated by the receptor tyrosine kinase are continuously emerging, highlighting the fact that there is still much to discover about the EGFR before we can optimally fine-tune effective EGFR-targeting therapies. In this review, we will examine our knowledge on how the mitogen EGF activates the EGFR and its signaling pathways. We will also explore how aberrations in the EGFR lead to oncogenesis by focusing on the role of the EGFR in cell cycle progression, including on their effect in activating Cyclin D-CDK4/6. Furthermore, we will examine the rationale behind anti-EGFR treatment options, and their possible synergisms with recently developed CDK4/6 inhibitors.

\subsection{Brief History—Discovery}

Stanley Cohen's Nobel Prize-winning studies provided the seminal work for the EGFR field. In 1959, together with Rita Levi-Montalcini, Cohen was examining the effects of a newly discovered 
growth factor, the nerve growth factor (NGF), on newborn mice. Their source of NGF consisted of crude extracts prepared from mouse salivary glands. Dr. Levi-Montalcini had noticed that unexpected "side effects" were present in whole fraction preparations unrelated to the effects seen in NGF-purified fractions [2]. The responsible component was causing precocious tooth eruption and eyelid opening in the newborn mice. Cohen focused on these "side effects" and isolated the sole component [3] and termed it the epidermal growth factor [4], as it seemed to enhance the epidermal growth of animal cells in vivo [5] and in vitro [4]. Cohen soon discovered that murine EGF could enhance DNA synthesis in cultured fibroblasts from humans, which allowed him to discover the human counterpart of murine EGF [2]. The question soon turned to the mechanism of action of EGF. At the time, it was thought that peptide hormones would bind to receptors on the plasma membrane, but then be released into the extracellular environment. However, Cohen showed that EGF could bind a membrane-bound $170 \mathrm{kDa}$ protein, the putative epidermal growth factor receptor (EGFR) [6-8]. This binding would cause the EGF and the EGFR to be internalized into the cell, which would subsequently be degraded through a lysosome-dependent manner. Using the A-431 cell line, a human epidermoid carcinoma cell type rich with EGFR, he discovered that the addition of EGF caused the phosphorylation of the EGFR. Originally identified as a threonine kinase, it wasn't until the fact that the Rous sarcoma virus was found to encode a tyrosine kinase that Cohen's lab correctly identified the EGFR as a receptor tyrosine kinase [9], the first of its kind to be defined.

The EGFR's link to cancer was first recognized when the transforming v-ErbB oncogene of the avian erythroblatosis virus was found to be a mutant homolog of human EGFR [10,11]. The v-erbB oncogene was found to contain recombinations of the transmembrane and cytoplasmic domains of the EGFR [12], implicating EGFR aberrations to cancer. In addition to mutations, overexpression of EGFR was then observed to promote cancer progression, first in carcinomas $[13,14]$, and later on in sarcomas [15], non-small cell lung cancer (NSCLC) [16] and malignant gliomas [17]. The levels of EGFR would soon be found to predict tumor grade, patient prognosis, and relapse in cancer $[18,19]$. In the lab, it was found that EGF addition to EGFR-overexpressing cells caused a transformation phenotype in NIH $3 \mathrm{~T} 3$ cells that could form tumors in nude mice, largely due to its role in promoting cell cycle progression $[20,21]$.

It is well established that the ErbB family of proteins can promote a multitude of pro-oncogenic biological processes, including cell proliferation, angiogenesis, inhibition of apoptosis, cell motility, adhesion, and metastasis. It is clear that ErbB family members represent promising targets for pharmacological inhibition. Various cancer treatment options targeting mutated or overexpressed ErbBs have reached the clinics, and tend to show efficacy and improve long term outcome. However, it has become evident that cancer cells can employ various molecular mechanisms to escape cell death mediated by anti-ErbB treatments. The characterization of these pathways has taken centre stage, in hoping that these discoveries will lead to effective combination therapies.

\subsection{ERBB Family Members}

The human ErbB gene family includes EGFR/ERBB1/HER1, NEU/ERBB2/HER2, ERBB3/HER3, and ERBB4/HER4. Being able to form homo- and heterodimers with one another, these family members can form a total of 28 different combinations with each other [22]. ERBB2 does not contain a ligand-binding domain, and no direct ligand for it has ever been identified, yet ERBB2 appears to be the preferred binding partner to its family members [23-25], as its dimerization arm is constitutively exposed [26]. ERBB3 does not contain a kinase domain, therefore ERBB3 homodimers possess little autophosphorylation activity, albeit some is present [27]. However, ERBB3 can still be phosphorylated and induce potent downstream signaling [25].

In Caenorhabditis elegans, the ErbB gene is a single receptor, with a single ligand [28]. In Drosophila, ErbB is made up of one receptor and four ligands [29]. EGFR pathways signaling studies in Drosophila have yielded tremendous information, especially regarding embryogenesis [30]. 


\subsection{EGFR Expression}

EGFR is mapped to chromosome 7 short arm q22, spanning $110 \mathrm{~kb}$ of DNA divided into 28 exons [31,32]. In normal cells, the expression of EGFR is estimated to be from $40,000-100,000$ receptors per cell [33], whereas overexpression of more than $10^{6}$ receptors per cell is observed in cancer cells [34].

EGF regulates its own receptor, as it increases EGFR RNA expression [35] by stimulating the expression of ETF (EGFR-specific transcription factor) [35,36]. Other proteins that modulate the EGFR promoter include E1A [37], Sp1 [36,38], and AP2 [39]. The interaction between DNA topoisomerase I and c-JUN has also been shown to regulate EGFR gene expression [40].

\subsection{Physiological Role of EGFR}

Almost all cell types possess ErbB family members, with the exception of hematopoietic cells [41]. EGFR family genes are critical to the normal embryogenesis of vertebrates [42]. Null mutations of any of the ErbB genes in mice cause embryonic or perinatal lethality $[43,44]$. The specific phenotype depends on the genetic background of the mouse, but also on the ErbB family member that is knocked out. The lethality of EGFR null mice have been shown to be due to abnormalities in organs including in the brain, skin, lung, and gastrointestinal tract, as well as to the renewal of stem cells $[45,46]$. ERBB2 null mice die from cardiac trabeculae dysfunctions, but also exhibit malformations in motor nerves and sensory ganglia [47-49]. ERBB3 null mice suffer from defective cardiac formation [50] and severe neuropathies [51]. ERRB4 knockout mice die from defective trabeculation in the heart, similar to ERBB2 knockout mice, and also exhibit improper hindbrain-derived cranial neural crest cell migration [52-54]. EGFR also plays roles in rat embryonic skin maturation, hair follicle development, hair cycling [55], and corneal development [56].

In adolescence, EGFR family genes play key roles in mammary ductal development. Female mice with a T743G substitution that impairs tyrosine kinase activity fail to develop proper mammary glands, due to defective ductal growth, causing their pups to die from malnutrition [57-59].

EGFR activity remains high in most parts of mature CNS [60]. However, in mouse and rat astrocytes, EGFR is present in high levels in developing astrocytes, but becomes absent in mature astrocytes $[61,62]$. Interestingly, CNS disorders including ischemia, tumor development, and neurodegenerative diseases can re-upregulate EGFR in astrocytes, in a response termed reactive astrogliosis $[63,64]$.

\subsection{EGFR Structure}

The EGFR is synthesized as a 1210 residue precursor that is cleaved at the $\mathrm{N}$-terminal to result in the mature 1186 residue transmembrane EGFR [11]. From N-terminal to C-terminal, the EGFR consists of (1) an extracellular ligand binding and dimerization arm (exons 1-16), (2) a hydrophobic transmembrane domain (exon 17), and (3) the intracellular tyrosine kinase and C-terminal tail domains (exons 18-28) [43]. Here, we will describe the structure and function of each domain in the EGFR.

The extracellular region of the EGFR is composed of 621 amino acids and is subdivided into four domains, I (amino acids 1-133, exons 1-4), II (amino acids 134-312, exons 5-7), III (amino acids 313-445, exons 8-12), IV (amino acids 446-621, exons 13-16). Domains I and III are leucine-rich fragments that participate in ligand binding. Domain II forms homo- or hetero-dimers with the analogous domain of family members. Domain IV can form disulfide bonds to domain II, and links to the TM domain. Domains II and IV do not make contacts with the ligand, and are cysteine-rich regions.

The TM domain is a 23 amino acid long hydrophobic single pass membrane structure, that anchors the receptor to the membrane [65]. It is 23 amino acids long, from Ile622 to Met644 [66]. The EGFR TM domain has been suggested to play a role in dimerization, as the N-terminal region of the TM helices have been hypothesized to contact during dimerization [67]. The role of the TM domain has been better 
studied in ERBB2, as mutations in the ERBB2 TM domain augment dimerization [68]. Furthermore, the ERBB2 TM may also be involved in aligning the intracellular domains through rotational twisting [69].

The intracellular domain is 542 amino acids long, and includes the flexible juxtamembrane segment ( 40 aa), the tyrosine kinase domain (amino acids 690-953, exons 18-24), and the C-terminal tail (amino acids 954-1136, exons 25-28) [70]. The tyrosine kinase domain can be divided into an $\mathrm{N}$-lobe (mainly a $\beta$-sheet structure) and a C-lobe (a mainly $\alpha$-helical structure), with an ATP-binding site located between the two lobes [71]. Transautophosphorylation relies on the interaction of the $\mathrm{N}$-lobe of one receptor to the C-lobe of the other [72]. The kinase domain also contains lysine residues that are the primary sites of receptor ubiquitination. The C-terminal tail includes various tyrosine residues, which when phosphorylated, allow the anchoring of a variety of intracellular proteins to the activated receptor. These proteins then participate in the signal transduction relay.

\subsection{EGFR Mutations}

EGFR mutations occur at mutational "hotspots" in the extracellular region, the kinase domain, and the C-terminal tail [1]. Certain types of cancers appear to favor certain locations for their mutations. For example, most glioblastomas appear to harbour aberrations to the ectodomain, whereas non-small cell lung cancers (NSCLCs) almost exclusively harbour kinase domain mutations [1,73]. Colorectal cancers less commonly harbour EGFR gene mutations [74]. Rather, around 50\% of colorectal cancers have been reported to contain EGFR gene amplification, with a three- to five-fold increase in copy number [75]. The EGFR is also overexpressed in $40-80 \%$ of NSCLC [76]. Most EGFR mutations and truncations promote the constitutive activation of EGFR by stabilizing ligand-independent dimerization with ERBB family receptors $[77,78]$. Furthermore, some mutations allow the receptor to escape downregulation by endocytosis [79]. Mutations in the EGFR transmembrane region are rarely seen.

EGFR ectodomain oncogenic alterations often cause the loss of the inhibitory regulatory domains for dimerization. The most famous EGFR ectodomain mutant is the viral EGFR homologue, v-ERBB, which completely lacks the ectodomain, and exists primarily in dimers [10]. In addition, the EGFR variant EGFRvIII arises from the genomic deletion of exons 2-7, and occurs in approximately $20 \%$ of glioblastomas [73,79]. Interestingly, EGFRvIII displays ligand-independent signaling, but has low constitutive activity. The low constitutive activity is enough to impart cancer cells with increased signaling, however its growth advantage is due to the fact that these receptors are not downregulated by endocytosis $[79,80]$.

In the kinase domain, the most commonly seen EGFR point mutation is L858R, and makes up approximately $45 \%$ of mutations in the tyrosine kinase domain [81,82]. Termed a "classical" activating mutation, the L858R mutation of the activation loop confers 50-fold more kinase activity and higher $\mathrm{K}_{\mathrm{M}}$ for ATP than wild type EGFR $[83,84]$. Molecularly, crystallographic analysis suggests that the leucine to arginine substitution causes the activation loop to "flip out," which destabilizes the auto-inhibited conformation normally found in non-ligand bound EGFR, essentially leading to a stabilized active conformation [72,85]. Another classical class of activating mutations in the kinase domain are the various EGFR exon 19 in-frame deletions, commonly observed in NSCLC [86]. Another kinase domain mutant, T790M, is often referred as the "gatekeeper residue," and is notorious for conferring resistance to pharmacological EGFR tyrosine kinase inhibitors in addition to increasing EGFR phosphorylation levels $[87,88]$. While the mechanism of resistance of T790M is not yet known, the bulkier methionine side chain may provide steric hindrance to TKI binding [89]. T790M is located in exon 20, and other insertions in exon 20 have also been found to confer resistance to TKIs [86].

\section{Signal Transduction}

The first studies on the EGF in animals showed that it stimulated epidermal proliferation and keratinization [5]. We now know that the EGF can stimulate cell proliferation, cell differentiation, cell growth, migration, and inhibit apoptosis. It has been shown that the addition of EGF to HeLa cells activates the EGFR to cause the global phosphorylation of 2244 proteins at 6600 sites [90]. Furthermore, 
it was shown that EGF stimulation causes significant differences in expression of 3172 genes and 596 proteins in human mammary epithelial cells (HMEC) [91]. Another study showed that the ERBB signaling network is estimated to encompass 122 proteins and 211 interaction [92]. Even without factoring in other types of post-translational modifications, it is clear that the effects of the EGF on the cell are profound and wide-ranging. The signal transduction mediated by the EGFR is extremely complex. It begins with the EGFR being activated by one of its ligands, leading to receptor dimerization, the transphosphorylation of the C-terminal tail, and finally the propagation of the signal through various intricate signaling pathways to induce the expression of new genes. EGFR mutations and truncations can impart the EGFR with ligand-independent signaling, which lead to the upregulation of various pro-oncogenic processes, including chronic cell cycle proliferation.

\subsection{Ligand-EGF}

Human EGF is a $6 \mathrm{kDa}$ protein made up of 53 amino acids. Physiologically in humans, various organs regulate their innate EGF concentrations [93]. For example, EGF is found at high concentrations (50-500 $\mathrm{ng} / \mathrm{mL})$ in bile, urine, milk, and prostate fluid, at medium concentrations (5-50 $\mathrm{ng} / \mathrm{mL}) \mathrm{in}$ tears, follicular fluid, sperm, and seminal plasma, and at low concentrations (1-2 ng/mL) in plasma, serum, and saliva (mice differ in that their saliva are high in EGF) [93,94]. The sources of EGF from the human body have been documented previously [95]. EGF is implicated in the morphogenesis of teeth, brain, reproductive tracts, skin, gastrointestinal tracts, in cardiovascular differentiation and function, epithelial regeneration, and corneal epithelia (reviewed in [96]). However, no disorders arising from EGF deficiency have been identified, likely due to the presence of other EGFR ligands [97].

Aside from the EGF, six other EGFR ligands have been described. These include transforming growth factor- $\alpha$ (TGF- $\alpha$ ), amphiregulin (AREG), epiregulin (EREG), betacellulin (BTC), heparin-binding EGF-like growth factor (HB-EGF), and epigen (EPI). EGF, TGF- $\alpha$, and amphiregulin are specific ligands only for the EGFR [98]. TGF- $\alpha$ is composed of 50 amino acids, and displays 35-40\% homology with EGF [41]. BTC, HB-EGF, and EREG show dual specificity for both EGFR and ERBB4 [99]. Notably, the neuregulins (NRGs) can bind both ERBB3 and ERBB4, or only ERBB4, depending on the subclass [100-103].

Each ligand appears to activate the EGFR in the same way: through ligand binding, receptor dimerization, receptor transautophosphorylation, and the recruitment of signaling proteins or adaptors. In addition, all EGFR ligands induce EGFR internalization and trafficking to early endosomes [104]. Despite these similarities, the activation of the EGFR by different ligands has been shown to cause distinct downstream biological activities [24,97]. The exact mechanism by which each ligand brings about distinct biological effects is unclear, however some theories have been put forward. One theory is that each ligand induces preferred dimer pairs within the EGFR family, which leads to a distinct signal. It was shown that although EGF and NRG can both stimulate ERK1/2, EGF acts primarily through EGFR and ERBB2 heterodimers to preferentially stimulate PKC, whereas NRG acts primarily through ERBB2 and ERBB3 heterodimers to preferentially stimulate AKT [105]. Another theory examines the contribution of the type of ligand to the fate of the receptor. Following endocytosis, endocytic sorting generally targets receptors bound with EGF for lysosomal degradation or recycling, with HB-EGF and BTC for lysosomal degradation, with TGF- $\alpha$ and EPI for receptor recycling, and with AREG for fast and slow EGFR recycling [104,106]. The differential sorting may be due to the different $\mathrm{pH}$ sensitivities of each ligand-receptor combinations. A study reported that although EGF and TGF- $\alpha$ bind the EGFR with similar affinities at relatively neutral $\mathrm{pH}$ (7.4), a drop in $\mathrm{pH}$ to 6 (to mimic acidification in EEs) led to the dissociation of TGF- $\alpha$ from the EGFR that allowed the receptor to be recycled back to PM, whereas the EGF-EGFR complex remained stable and led to its trafficking to degradation components [107]. The study also showed that recombinant EGF mutants with different affinities for the EGFR altered the endosomal sorting of the EGFR. Another study showed that the recycling of TGF- $\alpha$-bound EGFR back to the PM effectively prevents the downregulation of the EGFR, thus allowing more pronounced and sustained EGFR signaling [108]. Therefore, since the ligand affects the location of the EGFR within the cell, each ligand is likely able to create distinct signaling patterns 
that tunes the biological response respectively. Lastly, it is hypothesized that each ligand may cause different conformations of dimerized receptors, resulting in differential accessibilities of substrates to the C-terminal tail [109]. The exact mechanism of the differential signaling is still a subject of research.

Most growth factors act in a paracrine fashion, where the growth factor produced from a cell targets a neighboring cell. However, examples of autocrine mechanisms have been documented. Originally elaborated by Sporn and Roberts [110], this dangerous situation puts the cell in charge of its own cell division. Many viruses take advantage of this autocrine signaling to turn on the cell's DNA replication program in order to duplicate its own genome. For example, the EGFR is the target of sarcoma virus-transformed mouse fibroblasts, which encodes EGF-like molecules to stimulate its own growth [111].

\subsection{EGFR Dimerization}

For full EGFR activation, ligand binding and EGFR dimerization are crucial. However, it was a matter of controversy which process occurred first. It is now well accepted that for the activation of the EGFR, EGF-binding to each EGFR monomer precedes EGFR dimerization. Originally observed by Yarden and Schlessinger [112,113], the ability to visualize crystal structures have shown that mechanistically, prior to ligand binding, domain II is folded into domain IV via disulfide bonds, in a "tethered" conformation that auto-inhibits dimerization [26,114]. EGF binding to the EGFR monomers at domains I and III promotes a domain rearrangement to expose the dimerization arm in domain II, leading to a stabilized "open" or "extended" conformation. [26,114]. Dimerization of domain II is followed by rearrangements in the transmembrane domain that also leads to rearrangements in the juxtamembrane segment. The intracellular juxtamembrane segment then forms interactions with the kinase domain that are important for the formation and stability of the EGFR dimer [115]. The EGFR dimer is an asymmetric EGFR dimer pair, in that the C-terminus of the activating kinase inserts into the active site of the receiving kinase, so that this allosteric interaction can activate the receiving kinase, resulting in transautophosphorylation [72]. This is different to other RTKs, where dimerization induces a conformational change that induces each receptor monomer to activate itself.

There is evidence that preformed unliganded EGFR dimers do exist [116-118], however their precise structure and function are still controversial. Using quantum dot-based optical tracking of single molecules, researchers found that these preformed temporally-transient dimers were observed to be stabilized together at the dimerization arms, and were enriched at the cell periphery in regions of high actin and EGFR expression [119]. Some researchers have concluded that these preformed EGFR dimers may be primed to bind EGF [116,117]. However, others have argued against this, showing that preformed extracellular dimers of the EGFR are structurally heterogeneous [120,121]. Moreover, isothermal titration calorimetry measurements showed that pre-dimerized EGFRs did not have enhanced ligand binding, whereas ligand binding could promote dimerization [120]. However, these studies were conducted using only the extracellular region of the EGFR that was engineered to self-dimerize with the addition of a dimerizing $F_{c}$ domain or of a dimeric leucine zipper. The characterization of the interactions between EGFR domains remains difficult since many experiments are carried out predominantly with isolated domains, either extracellular, TM, or intracellular. As such, it is difficult to understand the synergy between each domain throughout ligand activation [122].

The site of EGFR dimerization is considered "receptor-mediated", in that the ligand does not make a direct contribution to the dimerization interface [22]. Each EGFR monomer binds an EGF ligand, and the receptors interact through domain II to form the dimer interface. This is in stark contrast to other RTKs that use the ligand as a bridge between receptors to form the dimer. The other extreme is "ligand-mediated" dimerization, where the ligand is itself a dimer and bridges together two receptors by their ligand-binding fragments. For example, two nerve growth factor molecules bridge together two TrkA receptors without the receptors ever making contact. Two intermediatory forms of dimerization have also been described. The first is the formation of a ligand-mediated dimer 
that includes receptor contacts, such as for c-KIT and stem cell factor. The second, such as in the FGFR, includes a combination of bivalent ligand binding, direct receptor-receptor contacts, but also requires an accessory molecule [22].

Although EGFR has been proclaimed as a prototypical, its unique "receptor-mediated" mechanism of dimerization and its ability to transautophosphorylate make it anything than such. These subtle differences lead to approaches by which pharmaceutical targeting of the EGFR could take advantage of these facts.

\subsection{Signaling Pathways}

The signal transduction pathways activated by the EGFR comprise the most important reasons the EGFR has been studied to such lengths. The powerful capacity of each of the multitude of pathways under the EGFR's control to drive cell proliferation and resist apoptosis has formed a strong motivation for their cancer-related researches. Large strides have been accomplished in elucidating the pathways involved in mediating EGFR activity. Current research largely focuses on the crosstalk and compensation between pathways, so to elucidate how cancer cells develop resistance to pharmacological inhibition of pathways and how to properly intervene. The metabolic alterations mediated by these pathways are also of focus. Here, we will review the activation mechanisms by which the EGFR activates the ERK MAPK, AKT-PI3K, and PLC- $\gamma 1-P K C$ pathways, focusing on the molecular interactions between each protein in the pathways (Figure 1). We will focus on the important domains and amino acids that help propagate the signaling pathways.

\subsubsection{EGFR Transautophosphorylation}

Of the four family members, the EGFR signals to the largest number of unique signaling pathways, including the ERK MAPK, PI3K-AKT, SRC, PLC- $\gamma 1-P K C$, JNK, and JAK-STAT pathways. As these pathways are inter-linked, the activation of the EGFR actually stimulates an entire signaling network associated with a wide number of outcomes, such as cell proliferation, growth, differentiation, migration, and inhibition of apoptosis. Many proteins within the EGFR's signal transduction network have been the subject of pharmaceutical targeting in malignancies, illustrating the potency of the receptor.

Binding of EGF to the EGFR leads to the transphosphorylation of various tyrosine residues on the intracellular C-terminal tail. The tyrosine residues phosphorylated by EGF addition to cells include Y703, Y920, Y992, Y1045, Y1068, Y1086, Y1148, and Y1173. In addition to these autophosphorylated sites, there are also residues that are phosphorylated by other kinases, which interestingly appear downstream in the EGFR-activation cascade. For example, Y845 is phosphorylated by c-SRC [123], and T654 is phosphorylated by PKC [124]. Regardless, the newly phosphorylated tyrosine residues serve as docking sites for proteins harboring phosphor-tyrosine-binding residues, such as those with Src Homology 2 (SH2) and phosphotyrosine binding (PTB) domains [125]. Other important domains in the EGFR's signal transduction include SH3 (binds proline-rich), 14-3-3 (binds phosphoserine), bromo (binds acetylated lysine), and PH domains (binds phosphorylated inositides).

\subsubsection{RAS-RAF-MEK-ERK MAPK Pathway}

The RAS-RAF-MEK-ERK MAPK pathway may be the most important pathway in mediating the biological response of the EGFR. Bonafide proto-oncogenes RAS and RAF reside in this pathway. A major target of cancer therapy is MEK. ERK MAPK (mitogen-activated protein kinase) interacts with over a hundred substrates to initiate a wide array of physiological and pathological responses, including growth, proliferation, differentiation, migration, and inhibition of apoptosis [126,127]. Substantial bodies of evidence have supported the pharmacological targeting of this pathway for cancer treatment. Here, we will first briefly outline the domains and amino acid residues that mediate the binding of a protein to the next protein in the signaling cascade. Then we will explore each protein in more details. 


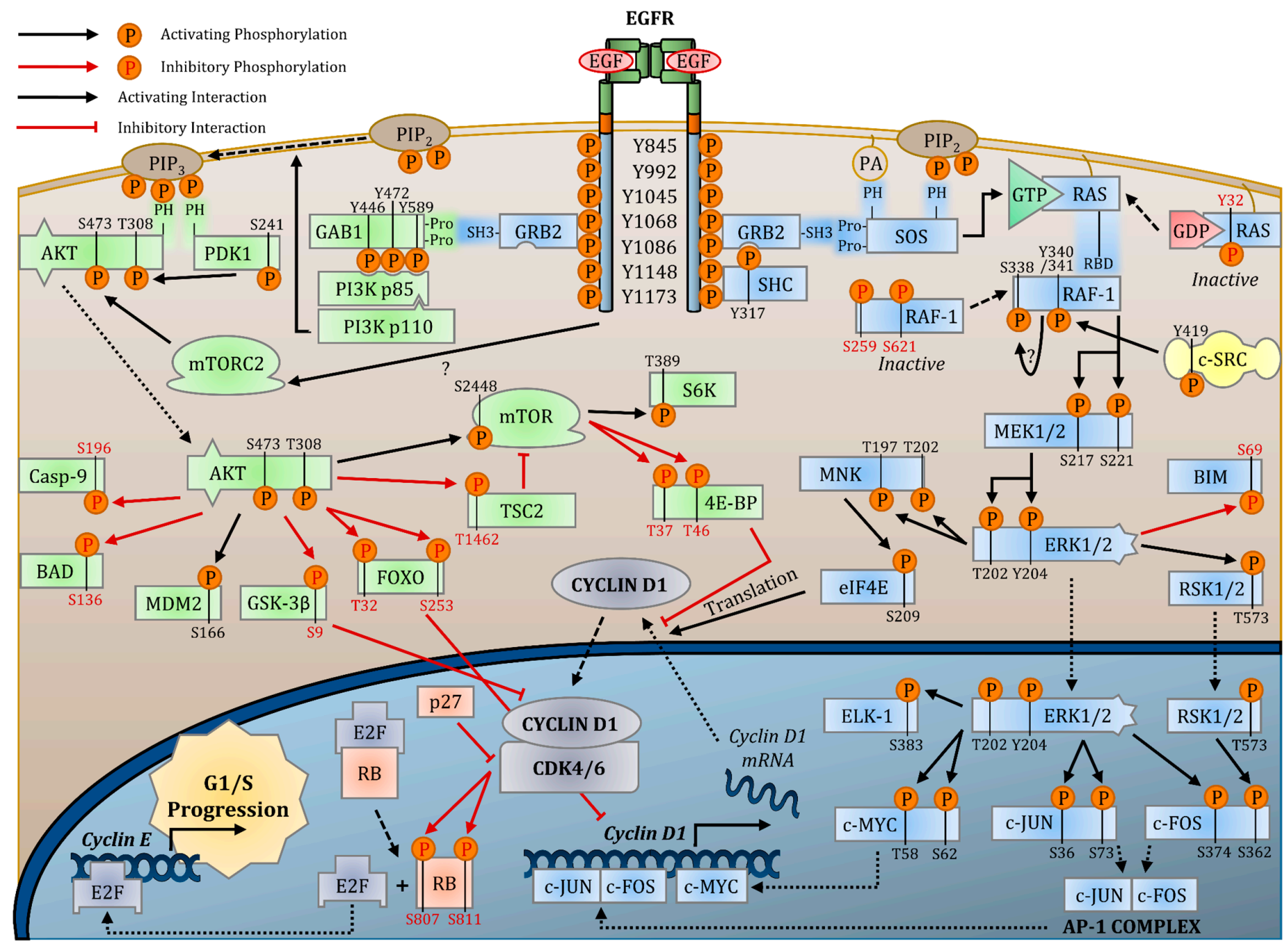

Figure 1. Epidermal growth factor receptor (EGFR) signaling pathways leading to G1/S cell cycle progression activated by EGF activation. Depicted are the RAS-RAF-MEK-ERK MAPK and PI3K-AKT-mTOR pathways. EGF activation of the EGFR induces receptor dimerization and transphosphorylation of the C-terminal 
domain. The phosphorylated C-terminal domain binds SHC and GRB2, along with PLC- $\gamma 1$ at Y992 (not pictured). The GRB2 SH3 domain recruits the proline-rich domains of SOS or GAB1 to initiate ERK MAPK or AKT signaling respectively. SOS is also recruited to the plasma membrane (PM) by the interaction of its PH (pleckstrin homology) domains with PIP 2 (phosphatidylinositol-4,5-bisphosphate) and PA (phosphatidic acid). SOS catalyzes the conversion of GDP to GTP of RAS. Active RAS uses its RAS RAF-binding domain (RBD) to recruit RAF-1. RAF-1 is activated by dephosphorylation and phosphorylation events, and activates MEK1/2. Activated MEK1/2 activates ERK1/2. ERK1/2 has various cytoplasmic and nuclear targets, which aid in the transcription and translation of Cyclin D1. For example, ELK-1 transcribes the c-FOS gene (not pictured), and the protein product together with c-JUN make up the AP-1 complex. The AP-1 complex as well as c-MYC induce the transcription of CYCLIN D1. On the other hand, the receptor-bound GRB2 also binds GAB1. GAB1 recruits the p85 regulatory subunit of PI3K, which binds the p110 catalytic subunit. PI3K converts $\mathrm{PIP}_{2}$ into $\mathrm{PIP}_{3}$ (phosphatidylinositol-3,4,5-triphosphate). $\mathrm{PIP}_{3}$ recruits AKT, and is phosphorylated and activated by PDK1 and mTORC2. AKT has many phosphorylation substrates, including various inhibitory phosphorylations to proteins that negatively regulate CYCLIN D1 activity such as GSK-3 $\beta$ (normally induces CYCLIN D1 degradation) and FOXO (normally represses CYCLIN D1 transcription). Furthermore, AKT inhibition of TSC2 allows the activation of mTOR, which inhibits the inhibitor of translation 4E-BP, thus allowing eIF4E-mediated translation of CYCLIN D1. Increased levels of CYCLIN D1 correlates with increased CDK4/6 activity, which phosphorylates RB. Phosphorylated RB releases the E2F transcription factor, which participates in the transcription of Cyclin E and leads to G1/S progression. The CDK inhibitor protein p27 inhibits CYCLIN D-CDK4/6 activity. However, activated ERK, c-MYC, AKT, all inhibit p27 activity. Importantly, the activated ERK MAPK and AKT pathways also inhibit various pro-apoptotic proteins, including BIM, Caspase-9, and BAD. 


\section{Overview of RAS-ERK MAPK Pathway}

Following receptor transphosphorylation, the activated EGFR's Y1068 and Y1086 residues bind directly to GRB2 (growth factor receptor binding protein 2), by its SH2 domain from residues 60-158 [128-130]. Additionally, the activated EGFR Y1148 and Y1173 residues can also recruit SHC (Src homology and collagen) [131-133] preferentially through it PTB domains, but also through its SH2 domain [134]. Notably, mutations to SHC of Arg175 in the PTB domain and of Arg397 in the SH2 to lysine prevent binding activity [134]. Regardless, these two adaptors link the ligand-activated EGFR to complex intracellular biochemical pathways. Upon binding to the EGFR, SHC is phosphorylated at Y317, which becomes a binding site for GRB2 [132,135]. SHC is also phosphorylated at Y239/240 by SRC, with this phosphorylation being important for SHC association with GRB2 [136]. GRB2's two flanking SH3 domains bind to the proline rich carboxy-terminal tail in SOS1 (son of sevenless 1), which includes residues 1069 to 1138 [137-141]. SOS is a guanine nucleotide exchange factor (GEF) for RAS small guanosine triphosphatase (GTPase), and activates RAS by inducing it to exchange GDP to GTP [142]. RAS can then interact with the RAF-1 Ras-GTP-binding domain (RBD), which contains amino acids 55-131 [143]. RAF-1 is a complex protein, but phosphorylation of its Ser338 and Tyr341 residues have been shown to be important binding sites for MEK1/2 [144-147]. RAF-1 directly activates MEK1/2 by phosphorylation at serine residues 217 and 221 [148]. MEK (mitogen-activated protein kinase kinase-MAPKK) $1 / 2$ are a rare class of tyrosine and threonine/serine dual-specificity kinases that activate ERK1/2. MEK1/2 phosphorylates the Thr-Glu-Tyr motif in the ERK1/2 activation loop, at T202 and Y204 [149]. ERK1/2 then phosphorylates multiple substrates to induce various biological response.

\section{SHC and GRB2}

Receptor transphosphorylation forms binding sites for both SHC and GRB2 adaptor proteins. Complexes that contain SHC have been reported to be better at activating RAS than those without SHC (i.e., direct binding of GRB2 to EGFR) [150]. Recruitment of GRB2 to the plasma membrane (PM) by SHC or EGFR occurs within two minutes of EGF treatment [151]. GRB2 was originally discovered for its role in EGF-induced SOS recruitment to the PM [128]. However, GRB2 can also recruit various other proteins to the PM. For example, GRB2 can bind phospholipase D, which hydrolyzes phosphatidylcholine to form the important secondary messenger phosphatidic acid (PA) and choline [152]. Importantly PA catalyzed by PLD2 forms an important binding site for subsequent SOS membrane recruitment [153]. The authors also found that although the SOS PH domain is recruited to the PM by $\mathrm{PIP}_{2}$, it is more efficiently recruited by PA. GRB2 can also bind CBL and CIN85, two important proteins for EGFR trafficking [154-156]. CBL is a ubiquitin ligase that ubiquitinates the EGFR and mediates its internalization and lysosomal sorting [93]. Although CBL can bind directly to the EGFR at Y1045, GRB2-mediated CBL recruitment to the EGFR is extremely important to properly respond to varying doses of EGF to mediate the proper endocytic response [157].

\section{SOS and RAS}

As mentioned, SOS recruitment to the PM requires GRB2, $\mathrm{PIP}_{2}$, and PA. In addition, non-substrate RAS can form a binding site for SOS recruitment to the PM, which can potentiate the important GTP exchange activity of SOS for RAS by 500-fold [158]. Moreover, SOS can interact with the PLC- $\gamma 1$ SH3 domain to help mediate RAS activation [159]. The exchange of GDP with GTP by SOS causes a conformational change in RAS, which turns on RAS activity. RAS is turned off by its intrinsic GTPase activity, which catalyzes its GTP to GDP, a process that can be accelerated by GTPase activating proteins (GAPs), such as NF1 (Neurofibromin 1) [160]. It was recently reported that RAS activity is inhibited by SRC-mediated phosphorylation at Y32, which reduces binding of RAS to RAF-1 and increases the GTPase activity of RAS, effectively shutting off two facets of RAS activity [161]. On the other hand, the phosphatase SHP2 has been identified by the same group to dephosphorylate pY32, thus implicating 
SHP2 as a direct activator of RAS activity [162]. Therefore, the latest model for the RAS activation cycle is as follows [163]. RAS activation requires SOS-induces GTP loading to RAS, along with SHP2 dephosphorylation of Y32 activate RAS. Activated RAS then engages with its downstream effectors. To turn off RAS, SRC phosphorylates Y32, causing the displacement of RAF, further followed by GTP hydrolysis to inactivate RAS.

Active RAS has the ability to activate three major downstream effectors. These include RAF-1 (also known as c-RAF), PI3K, and RalGDS (Ras-like guanine nucleotide-dissociation stimulator) [164-166]. The ability of RAS to activate these major pathways indicates why RAS-activating mutations or mutations within the RAS pathways are among the most common causative genetic alterations in cancer. It is estimated that up to $30 \%$ of all human tumours carry some mutation in the RAS genes [167]. However, despite over 30 years of research, RAS has been described as undruggable. Typically, to inhibit the activity of kinases, the ATP-binding pocket usually represents a target of pharmacological blocking with relatively high specificity. However, in the case of RAS, a functional GTP-catalyzing pocket is required to shut off its activity, precluding the site from pharmacological inhibition. Therefore, specifically targeting RAS is a difficult endeavor. Furthermore, the activation of $5 \%$ of total RAS molecules in the cell is estimated to be sufficient to induce full activation of ERK $1 / 2$, thus requiring an extremely efficient inhibitor to sufficiently inhibit RAS activity [168]. While the direct pharmacological inhibition of RAS is still being explored, alternative approaches to targeting RAS regulators such as PHLPP, SHP-2, and NF-2 have also been proposed $[162,169,170]$.

\section{RAF}

RAS itself does not fully activate RAF. Rather, RAS initiates RAF activation by translocating it to the plasma membrane, where additional membrane-localized activation events occur. RAS recruits RAF through the RBD region. In addition to this site, the RAS cysteine-rich domain (CRD, amino acids 139-184) has been shown to be important for the efficient activation of RAF-1 [171-174]. RAF is a serine-threonine protein kinase with complex regulation [175]. It has been estimated that activating mutations of RAF occur in $\sim 7 \%$ of all human cancers, with gain-of-function B-RAF mutations being largely associated with melanomas [176,177]. RAF is composed of an N-terminus regulatory domain and a C-terminus kinase domain. Only a small pool of RAF-1 is activated in ligand-stimulated cells [168]. Activated RAF-1 is phosphorylated at S338 and Y341, which are about 20 amino acids upstream of the ATP-binding domain in the regulatory region [178]. It has been reported that oncogenic RAS predominantly leads to S338 phosphorylation, and that activated SRC predominantly phosphorylates Y341 [179]. RAF S338 phosphorylation is induced by the addition of growth factor, however the molecular mechanism is unclear. It has been proposed that RAF S338 phosphorylation occurs by auto-phosphorylation [145]. RAF S338 may also be phosphorylated by PAK3 (p21-activated kinase 3) [180], although this has been debated [181]. PAK3 is activated by plasma membrane-localized small GTP-binding proteins CDC42 and RAC, which are also downstream targets of RAS. In addition, PAK1 has been shown to phosphorylate S338, but likely in a growth factor-independent context [182-184]. In addition to S338 and Y341, the phosphorylation of S471 in the catalytic loop, and of T491 and S494, have been reported to stimulate RAF-1 activity $[185,186]$. The phosphorylation of two other sites of RAF-1, S259 and S621 is inhibitory. Both pS259 and pS621 are bound by $14-3-3$, which keeps RAF-1 in an inactivate conformation $[187,188]$. The phosphorylation of S259 is catalyzed by AKT [189].

EGF treatment recruits 14-3-3-associated RAF-1 to the PM and leads to dissociation of 14-3-3 from RAF-1 [190]. It has been reported that RAS binding to RAF-1 displaces 14-3-3 from the N-terminus, but not the C-terminus of RAF-1 [190,191]. pS259 is dephosphorylated by PP2A (protein phosphatase 2A), and is essential for RAF-1 membrane association [192,193]. The significance of the pS621 site is controversial, although it appears RAS-binding to the site is necessary for RAF-1 kinase activity [194]. The requirement of the site has been difficult to study however, as mutations to 6621 cause the mutant RAF-1 to lose kinase activity [195]. Although 14-3-3 appears to inhibit RAF-1 activity, its reversible 
association with RAF-1 appear necessary for its activation via RAS-dependent interactions [194,196]. Furthermore, serine residues 29, 43, 289, 296, 301, and 642 have been reported as ERK-catalyzed phosphorylation sites, which are associated with feedback inhibition [197]. RAF-1 has also been shown to dimerize with itself or family member B-RAF to activate its kinase activity [198]. Interestingly, so far only cancers with mutant B-RAF V600G can be effectively treated with therapeutics [199]. Interestingly, in HeLa cells, the concentrations of RAS, RAF, and downstream proteins MEK and ERK have been estimated at 400,13,1400, and $960 \mathrm{nM}$ respectively, and revealed that RAF inhibition could be mostly effective in inhibiting this signaling pathway [200].

\section{MEK and ERK}

MEK1 and MEK2 are activated by RAF-1, its only known substrates [201]. Furthermore, the only known MEK1/2 substrates are ERK1/2, with ERK1/2 only known to be activated by MEK1/2 [127,199]. Constitutively activate MEK1 greatly reduces growth factor dependency for cell proliferation, yet MEK1/2 is not commonly found to be mutated in solid tumors, [202,203].

ERK1 and ERK2 are serine/threonine kinases that always appear to be activated together [204]. Unlike the narrow substrate specificity of RAF and MEK, ERK has over one hundred downstream cytoplasmic and nuclear substrates [205]. In the cytosol, it can activate RSK1 (p90 ribosomal S6 kinase 1) by phosphorylation at T573, a site located in the C-terminal kinase domain activation loop of RSK1 [206]. Phosphorylation of RSK1 at T573, as well as S221, S363, and S380 have been identified to be important for its activity [207]. The kinase PDK1 (phosphoinositide-dependent protein kinase 1), of the PI3K-AKT pathway, can also activate RSK [208]. RSK translocates to the nucleus to activate c-FOS and SRF [209]. Activated ERK itself also translocates to the nucleus to activate ternary complex factor (TCF) transcription factors, which play a major role in the induction of immediate early genes (IEGs) [210]. IEG products include c-FOS and c-MYC, which induce late-response genes, to promote various phenotypes associated with ERK signaling [211]. Moreover, nuclear ERK can activate ELK-1, ETS, SP-1, and c-JUN [136,212,213]. ERK can phosphorylate ELK-1 at S383, S389, and S422, residues located at the C-terminal transcriptional activation domain [214,215]. c-FOS and c-JUN make up components of the AP-1 (activator protein 1) complex, which functions as a transcription factor that binds to the CYCLIN D1 promoter to activate transcription of the important G1 driver [216,217] (see Section 3). c-FOS is phosphorylated at S374 by ERK1/2 and at S362 by RSK [218]. c-JUN is phosphorylated at $S 63$ and $S 73$ by ERK1/2 in mouse fibroblasts [219]. EGF-activated ERK1/2 has also been found to both stabilize and induce the expression of FOXC1, a transcription factor with implications in triple-negative breast cancer [220,221]. ERK also negatively regulates apoptosis by phosphorylation of the pro-apoptotic BH3-only protein BIM (BCL2-like 11) on S69, which induces BIM ubiquitination and proteasome degradation. ERK is also known to regulate pyrimidine synthesis, chromatin remodeling, ribosome synthesis, and protein translation (reviewed in [222]).

\subsubsection{PI3K-AKT-mTOR Pathway}

The PI3K-AKT-mTOR signaling cascade controls metabolism, proliferation, cell size, survival and motility. In cancer, this pathway is often hyper-activated due to activating mutations to EGFR family members, PI3K, AKT, and downregulation of the famous tumour suppressor PTEN, which antagonizes PI3K activity. The PI3K-AKT-mTOR pathway is also dysregulated in diabetes, autism, and aging [223].

PI3K was discovered in the 1980s by the Cantley group [224]. It was shortly found to be activated by EGF stimulation [225]. There are three classes of PI3K, Class I, II, and III, which defer in structure, regulation, and function [226]. Here, we will only discuss Class I PI3K, the major downstream effector of EGFR. Class I PI3K are further subdivided by subclass: subclass IA (PI3K $\alpha$, $\beta$, and $\delta$ ) is activated by receptor tyrosine kinases, and subclass IB (PI3K $\gamma$ ) is activated by G protein coupled receptors [227]. PI3K is comprised of a regulatory p85 subunit that mediates binding to the receptor, and a catalytic p110 domain that phosphorylates the 3-OH group of the membrane 
lipid phosphatidylinositol-4,5-bisphosphate ( $\left.\mathrm{PIP}_{2}\right)$ to generate phosphatidylinositol-3,4,5-triphosphate $\left(\mathrm{PIP}_{3}\right)[224,228,229]$. The newly formed $\mathrm{PIP}_{3}$ is a potent secondary messenger and is the predominant mediator of PI3K activity [230]. The strong signaling potential of $\mathrm{PIP}_{3}$ is highlighted by the fact that the PI3K antagonist PTEN, which dephosphorylates and limits the activity PIP $_{3}$. is frequently inactivated in cancer [231]. PIP 3 links the lipid kinase activity of PI3K to the network of downstream signaling pathways, including the $\mathrm{PH}$ (pleckstrin homology) domain-containing serine/threonine kinase AKT/PKB. PI3K also indirectly stimulates the production of phosphatidylinositol-3,4-bisphosphate (PtdIns $\left.(3,4) \mathrm{P}_{2}\right)$, which can also recruit $\mathrm{PH}$ domain-containing proteins, including AKT. Other than AKT, cells contain 50-100 downstream effectors of PI3K [232]. Other notable effector proteins of PI3K that contain PH domains are the RHO, RAC, RAS, ARF, and GAB1/2 proteins [232].

The recruitment of PI3K differs between ErbB family members following ligand stimulation. PI3K binds directly with ERBB3 and ERBB4 [233,234], but indirectly with ERBB1 and ERRB2 [235]. The p85 SH2 domain recognizes the phosphorylated Tyr-X-X-Met motif only present in ErbB3 and ErbB4 [233]. However, indirect interactions for ERBB1 and ERBB2 to PI3K are mediated by the adaptor protein GAB1 (GRB2-associated binder), which contains the canonical PI3K-binding sites [236]. However, the majority of GAB1 likely binds to the EGFR through GRB2, by the interaction between the GAB1 proline-rich domain with the GRB2 SH3 domain [237-239]. This causes the tyrosine phosphorylation of GAB1, at Y446, Y472, and Y589, which are binding sites for the recruitment of the p85 subunit of PI3K [236]. RAS can also bind and recruit PI3K by the p110 subunit, and a point mutation at K227E of PI3K has been shown to block p110 subunit binding of activated RAS [166,240,241]. In addition, CBL's Tyr371 and Tyr611 residues also bind to the p85 regulatory subunit of PI3K, allowing CBL to act as an adaptor to bring PI3K to the EGFR [235]. Moreover, PI3K dephosphorylation of Y688 on p85 by SHP1 (SH2 domain-containing phosphatase) is activating, whereas phosphorylation of the residue by c-SRC is inhibitory [242].

AKT (also known as Protein Kinase B, or PKB) is a serine/threonine kinase with a wide variety of substrates that impact cell survival, proliferation, metabolism, protein synthesis, growth, and migration. It is activated by a dual regulatory mechanism, requiring its translocation to the PM and phosphorylation at two conserved residues. Activated EGFR stimulates AKT translocation to the PM by activating the PI3K-induced formation of $\mathrm{PIP}_{3}$. AKT binds to $\mathrm{PIP}_{3}$ through its $\mathrm{PH}$ domain [243]. In addition, it has been found that EGF-induced ubiquitination of AKT through the Skp2-SCF E3 ligase also recruits AKT to the PM [244]. Once localized at the PM, AKT is phosphorylated at T308 and S473. T308 phosphorylation is necessary and sufficient for AKT activation, however maximal activation is achieved by phosphorylation at S473 $[245,246]$. PDK1 phosphorylates AKT at T308, a residue located in the kinase domain [247]. Active PDK1 is autophosphorylated at S241 [248]. Phosphorylation at the tail domain residue $S 473$ is mediated by mTORC2, through a little understood process that involves PI3K activity [223,249]. AKT activation is suppressed by the phosphatase PHLPP (PH domain leucine-rich repeat protein phosphatase), which dephosphorylates S473 [250,251], and T308 by PP2A [252].

There are three members of the AKT family: AKT1, AKT2, and AKT3. AKT2 and AKT3 have $81 \%$ and $83 \%$ amino acid homology to AKT1 respectively [232]. AKT isoform protein and mRNA levels have been characterized in various cell lines [253]. AKT1 and AKT2 are broadly expressed, whereas AKT3 is only expressed in the brain, heart, and kidney [254,255], which may explain why AKT3 is less well studied than the first two isoforms. There is no consensus on the role of each isoform in cells, due to the controversial pool of data regarding their function. AKT1 has been found localized to the cytoplasm and nucleus, AKT2 to mitochondria, and AKT3 to the nucleus and nuclear membrane [253], although their localization may differ based on the cell type [256]. AKT2 appears to be the main AKT responsible for glucose metabolism and the induction of apoptosis, which supports its mitochondrial role. In fact, Akt2 null mice seem unable to maintain glucose metabolism whereas Akt1 null mice maintain normal metabolism, but are smaller compared to normal mice [257-259]. Many Akt1 null mice suffer embryonic lethality, suggesting Akt2 and Akt3 cannot fully compensate for Akt1 activity [254]. In fact, it has indeed been observed that an Akt isoform will not compensate for the loss 
of another isoform, as Santi and colleagues found that siRNA ablation of one or two Akt isoforms did not significantly alter the subcellular localization of the remaining Akt isoform [253]. In terms of cancer, some studies have found that AKT2 may be the primary AKT for mediating PI3K-mediated metastatic processes [260,261], whereas others have concluded AKT1 to be as important [262-264]. Interestingly, some studies suggest opposing roles for the two isoforms. For examples, Irie and colleagues found that AKT2 promoted cell invasion, whereas AKT1 inhibited cell migration [261]. Similarly, Arboleda and colleagues showed that AKT2 overexpression promoted adhesion and invasion in human breast cancer cell lines, whereas AKT1 overexpression did not [260]. Another study found that AKT1 was important for lung tumor growth, whereas AKT2 inhibited this growth in mice [265]. Regardless, it appears both AKT1 and AKT2 aberrations can play tumourigenic roles. Overexpression of AKT1 has been reported in gastric and breast cancers [266,267]. Furthermore, the gain-of-function E17K somatic mutation of AKT1 occurs in breast, colorectal, and ovarian cancers [268]. AKT1 also appears to mediate tumour development in Pten haplodeficient mice [269]. On the other hand, AKT2 overexpression has been reported in ovarian, pancreatic, and colorectal cancers, and in hepatocellular carcinomas [270-273]. Genetic amplification of $A K T 2$ is prominently observed [270,274,275].

Regarding the regulation of AKT isoforms under the EGFR, all isoforms appear to be under the control of PI3K upon EGF stimulation in various esophageal cancer cells [276]. However, depending on the cell line, the AKT isoforms are differentially activated in a little understood RAS-dependant manner. EGF stimulation does not appear to change AKT expression levels [253]. In the absence of serum or growth factors, EGFR overexpression does not appear to constitutively activate AKT, however ERBB2 overexpression has been shown to do so in breast cancer cells [276,277].

AKT mediates its wide range of physiological responses through the activation or deactivation of several downstream proteins. Here, we discuss its role in mediating cell survival, in activating mTOR, and in metabolism. The role of AKT in cell proliferation, including its inhibition of GSK-3 $\beta$ (glycogen synthase kinase-3 beta), is discussed in Section 2.5.1.

In terms of cell survival, AKT functions in an anti-apoptotic manner by directly phosphorylating components of the cell death machinery. AKT phosphorylates the pro-apoptotic BAD (Bcl-2-associated death promoter) protein at $\mathrm{S} 136$, which inactivates $\mathrm{BAD}$ and prevents it from binding and inhibiting the anti-apoptotic BCL-X $X_{L}$ protein [278]. AKT also inhibits the catalytic activity of caspase-9 by phosphorylation at S196 [279], as well as the activity of FOXO1 by phosphorylation at T32 and S253 [280]. FOXO1 downstream gene targets include pro-apoptotic proteins BIM and the FAS ligand [281]. AKT also phosphorylates MDM2 at S166 and facilitates its translocation to the nucleus, where it ubiquitinates and downregulates p53, the well-known tumour suppressor [282-284].

One of the most important AKT pathways is to signal to mTOR (mammalian target of rapamycin). mTOR refers to two distinct complexes: mTORC1 is made up of raptor, GbL/mLST8, and negative regulatory subunits PRAS40 and DEPTOR, whereas mTORC2 contains rictor, mSin1, and Protor, GbL/mLST8 and DEPTOR [285]. mTORC1 is well known to regulate cell growth and autophagy. The mTOR receives stimulatory signals from growth factors through RAS and PI3K, as well as from nutrient inputs through amino acids, glucose, and oxygen availability [286]. Growth factor stimulation activates AKT, ERK, and RSK, which all phosphorylate and inactivate TSC2, an inhibitor of mTORC1. TSC1 and TSC2 suppress the activity of RHEB (Ras-like GTPase), which are needed to activate mTORC1 [287]. AKT directly phosphorylates TSC2 on five residues, including Ser939, Ser981, Ser1130, Ser1132 and Thr1462 [288,289]. ERK1/2 directly phosphorylates TSC2 on S664 [290]. Therefore, AKT, ERK, and RSK signaling converge to deactivate TSC2 and activates mTORC1, which phosphorylates 4E-BP (eurakyotic initiation factor 4E-binding protein) and S6K (p70 S6 kinase) [291]. These two effectors of mTORC1 have tremendous impacts on protein synthesis and cell growth, as 4E-BP is an inhibitor of translational inhibition and S6K is an activator of translation [223]. In terms of important phosphorylation sites, mTOR can be phosphorylated at $\mathrm{S} 2448$ by AKT and correlates with mTOR activity, although S2448A mutation still allows mTOR to activate S6K [292]. Furthermore, mTOR S1261 and S1415 phosphorylation have been reported to increase mTORC1 activity [293,294]. Downstream 
signaling occurs by phosphorylation of 4E-BP at T37 and T46, and of S6K at T389. mTOR activation also leads to the increased synthesis of CYCLIN D1, HIF1 (hypoxia-inducible factor 1), and growth factors including VEGF [295-297].

In the past decade, more research has been done to understand the role of the PI3K-AKT-mTOR pathway in the control of cell metabolism and glycolysis in cancer. In normal cells, high oxygen levels favor the use of oxidative phosphorylation over glycolysis, as it is a more efficient mechanism for generating ATP. Tumour cells however continuously use glycolysis even at high oxygen levels, a term coined aerobic glycolysis and also the principle behind the phenomenon known as the Warburg effect [298]. Although aerobic glycolysis is less efficient than oxidative phosphorylation at generating ATP, cancer cells continue using it, as it also synthesizes macromolecules that support cancer growth, such as ribose-5-phosphate, acetyl-CoA, and NADPH [298]. AKT is one of the main drivers of the Warburg effect, as it increases glucose uptake through the upregulation of glucose transporters [299,300]. In addition, various components of the PI3K-AKT-mTOR pathway also coordinate the uptake of nutrients, including glucose, glutamine, nucleotides, and lipids, to better support the enhanced proliferation and growth needs of cancer cells [301]. Activating mutations to the PI3K-AKT-mTOR pathway essentially reprogram the cell's metabolism, therefore targeting the unique metabolic dependencies of cancer cells through the PI3K-AKT-mTOR network may provide much therapeutic gain.

\subsubsection{PLC- $\gamma 1-P K C$ Pathway}

Prior to the discovery of $\mathrm{PI} 3 \mathrm{~K}$, interest on $\mathrm{PIP}_{2}$ focused on the results of its receptor-mediated hydrolysis by phospholipase C (PLC) [232]. Thirteen PLC isozymes have been described so far, and they are grouped within six classes based on their function and regulatory activation mechanisms [302]. Notably, the Plcg1 null knockout mouse is embryonic lethal at E9.0, in part due to the impairment of vasculogenesis $[303,304]$. PLC- $\gamma 1$, the protein encoded by Plcg1, has been shown to upregulate cell migration and invasion in vitro and in vivo, including upregulating metastasis in cancer $[305,306]$.

PLC- $\gamma 1$ binds directly to activated EGFR at Y992 and Y1173 using its SH2 domain [303,307-309]. PLC- $\gamma 1$ can also be recruited to the PM using its PH domain by binding PIP 3 formed by PI3K in response to EGF stimulation [310,311]. Phosphorylation of PLC- $\gamma 1$ at Y472, Y771, Y778, Y783, and Y1254 have been shown to be important for its activity [312,313]. Once recruited to the vicinity of the PM and activated, PLC- $\gamma 1$ hydrolyzes $\mathrm{PIP}_{2}$ into free intracellular 1,4,5-triphosphate $\left(\mathrm{IP}_{3}\right)$ and diacylglycerol (DAG), two important secondary messengers. $\mathrm{IP}_{3}$ binds to $\mathrm{IP}_{3}$-receptors at the endoplasmic reticulum to induce intracellular calcium release. Calcium release converges with the DAG pathway, as both DAG and $\mathrm{Ca}^{2+}$ activate protein kinase $\mathrm{C}$ (PKC). Phosphorylation at the activation loop of the kinase domain of PKC by PDK1 is necessary for its activation, and the specific residues that are phosphorylated have been characterized [314]. For example, PKC $\alpha$, one of the PKC isoforms activated by DAG, is phosphorylated at T497 to mediate its activation $[315,316]$. PKC has a host of cellular substrates, including EGFR, RAF-1, H-RAS, p21, GSK-3 $\beta$, RHOA, BAD, and BCL-2 [314]. Interestingly, PKC-dependent phosphorylation of EGFR T654 blocks EGF-induced EGFR activation [317]. Another substrate is phospholipase D (PLD). PKC phosphorylates PLD at S2, T147, S561, which mediates a large signaling network within the EGFR network [318-320]. Elevated PLD activity has been shown to contribute to fibroblast transformation by synergizing with EGFR and SRC [321,322] Phospholipase D hydrolyzes phosphatidylcholine to form phosphatidic acid (PA) and choline [152]. PA can interact with proteins such as RAF, RAC, PIP5K, mTOR, and S6K (reviewed in [323]).

\subsubsection{SRC}

The first virus ever identified to cause cancer encoded a viral isoform of c-SRC (also known as pp60src). The isoform, discovered in 1911 by Francis Peyton Rous, was named v-SRC, as it induced sarcomas in chickens [324]. v-SRC lacks an important Y527 (Y530 in human c-SRC) inhibitory site. 
In inactive c-SRC, Y527 is phosphorylated and induces an inhibitory intramolecular loop between itself and the SRC SH2 domain [325-327]. CSK (c-Src kinase) has been implicated as the kinase for Y527 [328,329]. SHP-1, SHP-2, PTP $\gamma$, and PTP-1B have been implicated as phosphatases for Y527 [330-333]. Furthermore, auto-phosphorylation at Y416 (Y419 in human c-SRC) displaces the pY416-containing activation loop from the catalytic cleft, thereby allowing SRC to gain access to substrates [334]. c-SRC was the first protein discovered to have tyrosine kinase activity [335-337]. Today, 11 nonreceptor tyrosine kinases make up the Src Family Kinases (SFKs), including c-Src, Fyn, Yes, Blk, Yrk, Frk, Fgr, Hck, Lck, and Lyn (reviewed in [338]). c-SRC, YES, and FYN are ubiquitously expressed in most tissues [339].

c-SRC is widely implicated in various aspects of EGFR signaling. For example, it can directly phosphorylate EGFR Y845, RAF Y341, SHC1, clathrin, and CBL [340]. It is not clear how EGFR-mediates c-SRC activation, however EGF stimulation indeed leads to c-SRC activation [341]. EGFR and ERBB4 both possess binding sites for SRC [109]. This activation is reportedly mediated by RAS and RAL [342]. EGFR and SRC have been reported to functionally synergize to form more aggressive cancers [341,343,344]. c-SRC may help activate STAT (signal transducer and activator of transcription) transcription factors in a JAK-independent manner [345]. c-SRC phosphorylates EGFR at Y845, which is not an autophosphorylation site [346]. However, Y845F mutation does not prevent c-SRC interaction to EGFR, nor does it affect ERK MAPK signaling [334,341]. Rather, Y845 has been suggested to regulate the autonomous lateral propagation of EGFR signals, which is the propagation of EGFR signals from one EGFR molecule to another without requiring binding of the ligand, potentiating EGFR kinase activity [347]. Phosphorylation of $Y 845$ has been suggested as a diagnostic marker for various cancer treatments, including for NSCLCs [348,349]. Interestingly, pY845 is targeted by two phosphatases, PTP1B and TCPTP [350,351].

Since SRC and EGFR appear to cooperate to increase tumorigenicity, dual inhibition of SRC and EGFR has been proposed, such as in head and neck squamous cell carcinoma and colorectal cancer [352,353]. However, as mentioned in Section 2.3.2, SRC negatively regulates RAS by phosphorylation at Y32, therefore SRC inhibition leads to increased RAS activity. In fact, EGF stimulation of SRC/YES/FYN triple knockout MEFs does not induce the phosphorylation of RAS as Y32, and as such exhibit increased RAS-RAF-1 interactions [161].

\subsubsection{Nuclear EGFR Signaling}

Several lines of evidence have shown that stimulation with EGF, as well as $\mathrm{H}_{2} \mathrm{O}_{2}$, UV, therapeutic agents, or ionizing radiation cause the EGFR to translocate to the nucleus, with nuclear EGFR signaling playing roles in cell proliferation, tumor progression, DNA repair [354-360]. High levels of nuclear EGFR have been found in various types of cancers [361-363], and nuclear EGFR signaling has been reported to mediate radio-resistance and chemo-resistance, such as to ionizing radiation and cisplatin [364-366].

Nuclear EGFR appears to be the full-length receptor [354]. The mechanism by which the EGFR translocates to the nucleus has been studied, but is still far from clear. It is suggested that the initial internalization of EGFR from the plasma membrane share similar features to clathrin-mediated endocytosis, in that the translocation is dependent on both clathrin and dynamin in cells treated with $100 \mathrm{ng} / \mathrm{mL}$ EGF [367]. Furthermore, similar to the majority of clathrin-mediated and non-clathrin-mediated forms of EGFR endocytosis, following internalization, the EGFR that is destined to the nucleus appears to first sort into endosomes, as nuclear EGFR has been shown to co-localize with endosomal markers [368]. However, there is no established mechanism for the translocation of endosomal EGFR to nucleus. Recent evidence suggests that EGFR is transported from endosomes to the Golgi, where coat protein complex I (COPI)-mediated retrograde transport later sends the EGFR to the endoplasmic reticulum [369]. For entry into the nucleus, much attention has been paid to the nuclear localization signal (NLS) present within the EGFR, that allows the EGFR to complex with importin- $\beta$ and to bind with the nucleoporins of nuclear pore complexes [368]. 
In the nucleus, the EGFR supports gene regulation by acting as a transcriptional co-activator. it has been shown that nuclear EGFR aids in the transcription of important cell cycle progression mediators, including CYCLIN D1 and c-MYC, among other proto-oncogenes [354,370]. The interaction of nuclear EGFR to the CYCLIN D1 gene promoter has been better studied, and has been shown to require EGFR interaction with two proteins, Mucin-1 (MUC-1) and RNA helicase A (RHA) [371,372]. In this way, nuclear EGFR signaling represents another way by which the EGFR promotes cell cycle progression, highlighting the breadth and redundancy of the EGFR signal transduction network in cancer progression.

\subsection{EGFR-Targeted Therapies}

The EGFR and its signaling pathways play key roles in oncogenesis. Two major classes of EGFR-targeted therapies have been developed. The first class of therapy developed includes humanized monoclonal antibodies against the EGFR extracellular domain, designed to block ligand binding or to mediate its downregulation [373]. The second class includes tyrosine kinase inhibitors (TKIs). TKIs are ATP mimetics that bind to the receptor's kinase pocket, which excludes ATP and prevents signal transduction [374]. Current US FDA-approved EGFR monoclonal antibodies include Cetuximab (Erbitux) and Panitumumab (Vectibix), and approved TKIs include Erlotinib (Tarceva), Gefitinib (Iressa), and Lapatinib (Tykerb), with the latter being a dual EGFR/HER2 inhibitor. These drugs have been approved for the treatment of non-small-cell lung cancer (gefitinib and erlotinib), metastatic colorectal cancer (cetuximab and panitumumab), head and neck (cetuximab), pancreatic cancer (erlotinib), and breast (lapatinib) cancer [375]. For example, gefitinib is efficacious as first-line treatment of metastatic NSCLC with EGFR exon 19 deletions or the L858R mutation [376]. Typically, EGFR inhibitors are used as monotherapy or in combination with cytotoxic chemotherapy or high-dose radiation.

Anti-EGFR therapy generally improves survival in EGFR-positive cancer patients [377]. TKIs are effective against cancer cells with EGFR L858R mutation and exon 19 deletion [376]. These two mutations account for $>90 \%$ of known activating EGFR mutations [81,378]. However, certain challenges still remain for the effective use of EGFR inhibitors. EGFR-positive tumours may be resistant to EGFR inhibitors, therefore screening for biomarkers that negatively predict response to anti-EGFR therapy has been suggested. The response to current anti-EGFR therapy can be modified by factors such as: the type of somatic EGFR mutations, EGFR gene amplification, increased autocrine EGFR ligands, and mutations in EGFR signaling pathway proteins ERBB2, K-RAS, B-RAF, PI3KCA, PTEN, and BIM (reviewed in [375,379]). However, whether tumours with these different factors benefit from anti-EGFR therapy is still confusing and uncertain [380]. For example, increased EGFR expression, typically determined by immunohistochemistry, was shown to not correlate with response to EGFR inhibitors [381,382], whereas another studied showed a positive correlation [383]. It has been speculated that these controversial results are due to the variation in EGFR antibodies used in immunohistochemistry, and that a standardized testing method be established [380]. For the common glioblastoma mutation EGFRvIII, the picture is a bit more clear, as currently approved EGFR-targeted treatments do not appear to be efficacious (reviewed in [79]). Alternative targeted therapies against EGFRvIII have been developed, including the vaccine Rindopepimut and the monoclonal antibody mAb806 (also known as ABT-806). Rindopepimut did not pass Phase III clinical trials and was discontinued in 2016. ABT-806 has passed Phase I [384], and an antibody-drug conjugate based on mAb806 called ABT-414 has also been advanced to Phase II (trial identifier NCT02573324). In terms of mutations to EGFR-pathway proteins, the efficacy of anti-EGFR therapy has been best studied in cancers with K-RAS mutations, with the consensus that these cancers will display primary resistance to EGFR inhibitors [385-390]. The FDA now requires an accompanying PCR diagnostic test for K-RAS prior to the prescription of cetuximab or panitumumab for colon cancer.

In addition to the challenge of implementing bio-markers for predicting response or resistance to anti-EGFR therapy, another challenge faced by the use of EGFR inhibitors is that the duration of 
the response is often limited and many tumours invariably develop resistance [379]. Secondary EGFR mutations may occur following TKI treatment that circumvent the initial benefits of the inhibitor. For example T790M mutations are the most common form of acquired resistance to TKIs [87,88]. Third generation EGFR TKIs are being developed to target T790M, including Brigatinib, HM61713, osimertinib, and rociletinib [391]. In addition to T790M mutations, secondary activating mutations within EGFR signaling pathways, such as mutations in the aforementioned $K-R A S$ or in PI3K can activate a signaling arm of EGFR regardless of EGFR activation status, rendering the EGFR inhibitor less effective. Also, epithelial to mesenchymal transition (EMT) has also been shown to frequently accompany the acquisition of resistance to TKIs, although the mechanism of the transition is still under investigation [392-396]. Lastly, skin toxicity remains a common side effect that frequently causes the discontinuation of the drug $[397,398]$. Other common side effects to EGFR inhibitors also include perturbations to the colon and cornea [399-401].

Inhibition of EGFR mostly causes cell cycle arrest in G1 prior to DNA synthesis [402-404]. The G1 arrest appears to be due to the upregulation of p27 $7^{\mathrm{KIP} 1}$ activity [402,403,405-411]. As this is partly cytostatic, combinations with DNA-damaging agents enhances anti-EGFR therapy. Pharmacological inhibition of EGFR is highly beneficial to radiotherapy, as ionizing radiation can actually stimulate EGFR and activate its cryoprotective signaling cascades. Other mechanisms of action by which EGFR inhibition decrease tumour growth include the inhibition of angiogenic activity by reducing the secretion of vascular endothelial growth factor (VEGF), decreasing cell invasion and metastasis by inhibiting the production of matrix metalloproteinase, and through the promotion of apoptosis in EGFR-addicted cancer cells (reviewed in [412]).

TKIs inhibit EGFR phosphorylation, which effectively downregulate ERK and AKT phosphorylations [413]. Many cancer cells that first respond to TKIs and EGFR antibodies later acquire resistance by upregulating MEK and ERK signaling [414]. For example, colorectal cancers often acquire resistance to cetuximab and panitumumab treatment [382,415]. The combination of EGFR inhibitors with inhibitors of the ERK1/2 or PI3K-AKT-mTOR pathway has been explored to increase the efficacy of EGFR therapies. MEK1/2 is a convergence point of aberrant activation from potent upstream signaling proteins, and due to its narrow substrate specificity, makes it a favorable target for therapeutical intervention. Two direct inhibitors of MEK, trametinib and cobimetinib, have been approved by the FDA for melanoma treatment $[416,417]$. The combinatorial treatment of MEK and EGFR inhibitors appears to overcome the acquired resistance to the EGFR inhibitors $[415,418]$. MEK inhibition in EGFR or ERBB2-driven cancers however is complicated, as it can lead to higher $\mathrm{PI} 3 \mathrm{~K} / \mathrm{AKT}$ activation. This is because inactivated MEK no longer activates ERK, which normally participates in the negative regulation of RTKs by phosphorylating EGFR and ERBB2 at the inhibitory T669 and T677 sites respectively [419]. Furthermore, the combination of a MEK inhibitor with EGFR and PI3K-AKT-mTOR pathway inhibitors is of great interest, although cell toxicity is an issue [420-422].

Therapeutic inhibition of the PI3K-AKT-mTOR pathway has been of intense study, and many potential inhibitors are currently under investigation for cancer. No PI3K or AKT inhibitors have reached the bedside so far, although three mTOR inhibitors have been approved by the FDA [423]. It has been shown that the therapeutic inhibition of the PI3K/AKT/mTOR pathways leads cancer cells to upregulate RTK activity. A mechanism by which AKT inhibition activates RTKs has been well described for the insulin receptor (IR). Here, mTOR-activated S6K inhibits IRS-1 (insulin receptor substrate 1), the adaptor protein that connects IR to PI3K, thereby negatively regulating PI3K signaling [424]. However, inhibition of EGFR family members by PI3K signaling does not rely on IRS-1. Instead, upregulation of EGFR, ERBB2, and ERBB3 in AKT-inhibited cells occurs through the de-repression of FOXO-dependant transcription of the receptors [425-429]. Furthermore, inhibition of the PI3K pathway also upregulates ERBB3 through an eIF4E-dependant mechanism [430]. These mechanisms of RTK upregulation when challenged with PI3K pathway inhibition maintains receptor activity, which produce more $\mathrm{PIP}_{3}$ to compensate for a loss of downstream signaling. Therefore, simultaneous treatment with an RTK inhibitor an PI3K-AKT-mTOR inhibitor has been used, with more favorable 
responses in vitro and in mice [431,432]. mTOR inhibition is also attractive since it may avoid the side effects associated with inhibition of PI3K-AKT, which have broader biological functions [433]. Importantly, targeting the PI3K-AKT-mTOR network can result in tumour resistance due to MYC activation [434]. Furthermore, another mechanism underlying tumour resistance to mTOR inhibition is the upregulation of autophagy [435].

\subsection{Effects of EGFR Signaling on Cell Cycle Progression}

The biological response of EGFR signaling is mediated by the activation of transcription factors. An important role of these transcription factors is to induce the production of CYCLIN D1, which forms a complex with CDK4/ 6 to initiate cell cycle progression. This EGFR-driven process of chronic proliferation represents one of the important facets behind EGFR-mediated oncogenesis. In this section, we will examine the mechanisms by which the EGFR initiates cell cycle progression, including its upregulation of CYCLIN D, and downregulation of cyclin-dependent kinase inhibitor proteins (CDKis). We will also examine the rationale for combining CDK4/ 6 and EGFR inhibitors, as this combination has been of recent interest [436].

\subsubsection{EGFR Activation of the CDK4/6-CYCLIN D Complex}

The best described role for the EGFR is to drive cells through G1, largely by inducing the activation of the CDK4/6-CYCLIN D complex. A pulse of EGF stimulation during early G1 and another at late $\mathrm{G} 1$ are sufficient to drive cells past the restriction point ( $\mathrm{R}$ point), the instant at which the cell commits to the completion of the cell cycle [437-439]. In cancers, activating mutations to the EGFR are correlated with higher expression levels of CYCLIN D [440-445]. These types of cancers also have lower patient prognostic values. EGFR-induced activation of the ERK and PI3K-AKT pathways plays a crucial role in the induction of CYCLIN D, which cascades into E2F-mediated progression past G1 and the R point. More specifically, CDK4/6- CYCLIN D phosphorylates RB at Ser807 and Ser811, causing the release of E2F, and free E2F helps transcribe key genes for the transition of G1/S, including CYCLIN E and CYCLIN A [446,447]. CYCLIN E binds CDK2 and further phosphorylates $\mathrm{RB}$ to complete its inactivation which drives cells to pass the R point and trigger S-phase entry [448]. Constitutively active oncogenic EGFR uses these pathways to continuously drive cells past the R point to promote hyperplasia.

The ERK pathway induces CYCLIN D1 expression through its activation of the AP-1 complex. Transcriptionally, ERK induces the expression of immediate early genes (IEGs), including c-FOS and c-JUN [211]. Post-translationally, ERK activates RSK, which activates c-FOS [209]. Nuclear ERK also directly activates c-JUN [213]. The activated c-FOS and c-JUN form the AP-1 complex, which binds to and primes the CYCLIN D1 promoter for transcription. Sustained ERK activation is required for progression of G1 into S, as transient ERK activation due to insufficient doses of growth factor does not lead to S-phase progression [449]. This has been proposed to be due to a poorly understood AP-1-dependant manner [449].

Concomitant PI3K-AKT signaling also upregulates Cyclin D1 activity. AKT signaling induces the transcription of $c$-FOS [450,451]. Active FOXO1 (also known as FKHR) transcription factors repress CYCLIN D1 expression [452]. However, AKT phosphorylates FOXO1 at T32 and S253, inhibiting FOXO1 and allowing the induction of CYCLIN D1 expression [281,453]. AKT also upregulates CYCLIN D1 activity through the inactivation of GSK-3 $\beta$ (glycogen synthase kinase-3 beta). GSK- $3 \beta$ is normally active in quiescent cells, and downregulates CYCLIN D1 activity in two ways. First, active GSK-3 $\beta$ causes CYCLIN D proteolysis by phosphorylating it at T286, which mediates its nuclear export and degradation [454]. In the same way, GSK-3 $\beta$ can mediate the degradation of another cyclin, CYCLIN E, by phosphorylation at S380 [455]. Secondly, active GSK-3 $\beta$ represses the transcription of IEGs, including AP-1, preventing the activation of the CYCLIN D1 promoter [456]. In response to EGF, GSK-3 $\beta$ is phosphorylated by AKT at S9 and inactivated, allowing the transcription of CYCLIN D1 and the stabilization of both CYCLIN D1 and CYCLIN E $[457,458]$. Lastly, mTOR-mediated CYCLIN 
D1 upregulation has been shown to be due to increased CYCLIN D1 mRNA translation as a result of 4E-BP1 inhibition, with the activation of eIF4E also being important [297]. The activation of eIF4E results from ERK phosphorylation of MNK1/2 (MAP kinase-interacting kinase 1/2) at T197 and T202, which then phosphorylates eIF4E at S209 [459,460].

Since CYCLIN D activates CDK4/ 6 to drive G1 progression, selective CDK4/6 inhibitors have been of intense recent research, driven by the availability of highly specific CDK4/6 inhibitors that also exhibit low patient toxicity and high tolerability [436,461-463]. These include the oral drugs palbociclib, abemaciclib, and LEE011, with both palbociclib and LEE011 having been recently approved for breast cancer in combination with letrozole, an aromatase inhibitor. CDK4 gene amplification was reported to be detected in $16 \%$ of breast cancers [464]. In addition to these cancers, CDK $4 / 6$ inhibition should be particularly actionable for tumours whose pathways hyper-activate CDK4/6. As such, the combination of CDK4/6 inhibitors with EGFR, ERBB2, MEK, or PI3K inhibitors have been of great interest [436,440,465]. Recently, the combination of CDK4/6 and EGFR inhibitors has been shown to be effective in blocking tumor resistance in mice [436].

\subsubsection{EGFR Inhibition of CDKi Activity}

The inhibition of EGFR in various cancers with EGFR inhibitors, including monoclonal antibodies or tyrosine kinase inhibitors, lead to G1/S arrest. Multiple lines of research suggest that the cause of EGFR inhibitor-induced G1/S arrest is the upregulation of p27 ${ }^{\mathrm{KIP} 1}$ activity [402,403,405-411]. p27 ${ }^{\mathrm{KIP} 1}$ inhibits CYCLIN D1-CDK4/6 activity, thereby preventing cells from progressing to $S$ phase [466]. Active p27 ${ }^{\mathrm{KIP} 1}$ also inhibits CYCLIN E-CDK2, further inhibiting exit from G1 [467]. p27 ${ }^{\mathrm{KIP} 1}$ has also been reported to induce apoptosis, although the mechanism has not been described [468,469]. Interestingly, p27 ${ }^{\mathrm{KIP} 1}$ also downregulates EGFR transcription [470,471]. As EGFR inhibitors strongly upregulate CDKi protein activity, the combination with CDK4/6 inhibitors likely provides a potent mechanism of G1/S arrest. There is much evidence that EGFR-mediated pathways ERK MAPK and AKT both suppress CDKi activity.

Many studies have shown that ERK1/2 contributes to p27KIP1 down-regulation [472-475]. For example, it was shown that ERK1/2 phosphorylates $\mathrm{p} 27^{\mathrm{KIP} 1}$ and promotes its degradation [475]. The inhibition of MEK by PD098059 increased the stability of p27 ${ }^{\mathrm{KIP} 1}$ [474]. Interestingly, ERK1/2 activation must be sustained until late G1 for progression into S-phase [449], which may be important for sustaining p27 ${ }^{\mathrm{KIP} 1}$ down-regulation. c-MYC, a commonly-mutated downstream effector of ERK, both activates CYCLIN D1 transcription and inhibits $\mathrm{p} 21^{\mathrm{CIP} 1}$ and $\mathrm{p} 27^{\mathrm{KIP} 1}$ activity, demonstrating the central role of c-MYC in G1/S progression [476,477].

Active AKT inhibits CDKis p21 CIP1/WAF1 and p27 KIP1 , by phosphorylation at Thr145 and, Thr157 and Thr198 respectively $[478,479]$. AKT also inhibits FOXO1, which normally induces the transcription of $\mathrm{p} 27^{\mathrm{KIP} 1}$ and $\mathrm{p} 21^{\mathrm{WAF} 1}$ [480,481]. Furthermore, GSK-3 $\beta$ inactivation by AKT downregulates p2 $7^{\mathrm{KIP} 1}$ levels, as GSK-3 $\beta$ normally represses $p 27^{\mathrm{KIP} 1}$ activity by both inhibiting $p 27^{\mathrm{KIP} 1}$ gene transcription and its protein interaction with CDK2 [482].

As the ERK and AKT pathways are inhibited by EGFR inhibitors, the subsequent upregulation of CDKis may provide synergy with CDK4/6 inhibitors to provide stronger G1/S arrest. In addition, the inhibition of these EGFR pathways allows the activation of pro-apoptotic proteins, including BIM, CASPASE-9, and BAD [222,278,279]. Therefore, this combination may effectively induce G1/S-arrested cancer cell death. However, this combination would need to effectively eliminate cancer cells before they demonstrate classical signs of resistance to EGFR inhibitors, including the de novo upregulation of EGFR signaling pathways (Section 2.4), as these would downregulate CDKis, as well as oppose CDK4/6 inhibition through the increased levels in CYCLIN D1. Therefore, a thorough ability to inhibit these pathways may hold the key to enhancing the efficacy of CDK4/6 inhibitors, and the continued effort to effectively control resistance to EGFR inhibitors, whether through the use of newer generation EGFR inhibitors, or with RAS-ERK or PI3K-AKT-mTOR pathway inhibitors may prove fruitful. 


\section{Conclusions}

The EGFR is at the head of one of the most important signaling pathways to mammalian cell physiology, and to oncogenesis. As this review has shown, tremendous amounts of research has been conducted on each of the many components of the EGFR. The sum of our knowledge from this vast array of research is allowing us to create even more effective drugs or drug combinations to target cancers with EGFR aberrations. In addition to understanding these signaling pathways in cancer, the spatial and temporal regulation of the EGFR remain understudied. For example, spatially, EGFR internalization by endocytosis results in EGFR signal attenuation, and has been studied by many groups $[93,483-486]$. Understanding how to target the EGFR to endocytosis and lysosomal degradation may present an avenue to downregulate EGFR levels. Furthermore, EGFR endocytosis may be used to internalize cytotoxic agents specifically to EGFR overexpressing cells, such as through the use of EGFR monoclonal antibodies conjugated to various drugs $[487,488]$. In addition to endocytosis, although the EGFR has been well-studied temporally for its role in G1, its function throughout the rest of the cell cycle-S, G2, and mitosis—remains rarely studied. For example, the EGFR has been seldom studied during mitosis, yet a differential regulation of its signaling and endocytosis is apparent [489-492]. Further investigations of EGFR function throughout the rest of the cell cycle are warranted.

Acknowledgments: P.W. is supported by a Natural Sciences and Engineering Research Council of Canada (NSERC) PGS D scholarship and by the President's Doctoral Prize of Distinction from the University of Alberta.

Conflicts of Interest: There are no conflicts of interest to report.

\section{References}

1. Pines, G.; Köstler, W.J.; Yarden, Y. Oncogenic mutant forms of EGFR: Lessons in signal transduction and targets for cancer therapy. FEBS Lett. 2010, 584, 2699-2706. [CrossRef] [PubMed]

2. Cohen, S. Origins of growth factors: NGF and EGF. Ann. N. Y. Acad. Sci. 2004, 1038, 98-102. [CrossRef] [PubMed]

3. Cohen, S. Isolation of a mouse submaxillary gland protein accelerating incisor eruption and eyelid opening in the new-born animal. J. Biol. Chem. 1962, 237, 1555-1562. [PubMed]

4. Cohen, S. The stimulation of epidermal proliferation by a specific protein (EGF). Dev. Biol. 1965, 12, $394-407$. [CrossRef]

5. Cohen, S.; Elliott, G.A. The stimulation of epidermal keratinization by a protein isolated from the submaxillary gland of the mouse. J. Investig. Dermatol. 1963, 40, 1-5. [CrossRef] [PubMed]

6. Cohen, S.; Carpenter, G.; King, L. Epidermal growth factor-receptor-protein kinase interactions. Co-purification of receptor and epidermal growth factor-enhanced phosphorylation activity. J. Biol. Chem. 1980, 255, 4834-4842. [PubMed]

7. Cohen, S.; Ushiro, H.; Stoscheck, C.; Chinkers, M. A native 170,000 epidermal growth factor receptor-kinase complex from shed plasma membrane vesicles. J. Biol. Chem. 1982, 257, 1523-1531. [PubMed]

8. Carpenter, G.; Lembach, K.J.; Morrison, M.M.; Cohen, S. Characterization of the binding of 125-I-labeled epidermal growth factor to human fibroblasts. J. Biol. Chem. 1975, 250, 4297-4304. [PubMed]

9. Ushiro, H.; Cohen, S. Identification of phosphotyrosine as a product of epidermal growth factor-activated protein kinase in A-431 cell membranes. J. Biol. Chem. 1980, 255, 8363-8365. [PubMed]

10. Downward, J.; Yarden, Y.; Mayes, E.; Scrace, G.; Totty, N.; Stockwell, P.; Ullrich, A.; Schlessinger, J.; Waterfield, M.D. Close similarity of epidermal growth factor receptor and v-erb-B oncogene protein sequences. Nature 1984, 307, 521-527. [CrossRef] [PubMed]

11. Ullrich, A.; Coussens, L.; Hayflick, J.S.; Dull, T.J.; Gray, A.; Tam, A.W.; Lee, J.; Yarden, Y.; Libermann, T.A.; Schlessinger, J. Human epidermal growth factor receptor cDNA sequence and aberrant expression of the amplified gene in A431 epidermoid carcinoma cells. Nature 1984, 309, 418-425. [CrossRef] [PubMed]

12. Olofsson, B.; Pizon, V.; Zahraoui, A.; Tavitian, A.; Therwath, A. Structure and expression of the chicken epidermal growth factor receptor gene locus. Eur. J. Biochem. 1986, 160, 261-266. [CrossRef] [PubMed]

13. Gusterson, B.; Cowley, G.; Smith, J.A.; Ozanne, B. Cellular localisation of human epidermal growth factor receptor. Cell Biol. Int. Rep. 1984, 8, 649-658. [CrossRef] 
14. Cowley, G.P.; Smith, J.A.; Gusterson, B.A. Increased EGF receptors on human squamous carcinoma cell lines. Br. J. Cancer 1986, 53, 223-229. [CrossRef] [PubMed]

15. Gusterson, B.; Cowley, G.; McIlhinney, J.; Ozanne, B.; Fisher, C.; Reeves, B. Evidence for increased epidermal growth factor receptors in human sarcomas. Int. J. Cancer 1985, 36, 689-693. [PubMed]

16. Veale, D.; Ashcroft, T.; Marsh, C.; Gibson, G.J.; Harris, A.L. Epidermal growth factor receptors in non-small cell lung cancer. Br. J. Cancer 1987, 55, 513-516. [CrossRef] [PubMed]

17. Wong, A.J.; Bigner, S.H.; Bigner, D.D.; Kinzler, K.W.; Hamilton, S.R.; Vogelstein, B. Increased expression of the epidermal growth factor receptor gene in malignant gliomas is invariably associated with gene amplification. Proc. Natl. Acad. Sci. USA 1987, 84, 6899-6903. [CrossRef] [PubMed]

18. Slamon, D.J.; Clark, G.M.; Wong, S.G.; Levin, W.J.; Ullrich, A.; McGuire, W.L. Human breast cancer: Correlation of relapse and survival with amplification of the HER-2/neu oncogene. Science 1987, 235, 177-182. [CrossRef] [PubMed]

19. Richard, J.; Sainsbury, C.; Needham, G.; Farndon, J.; Malcolm, A.; Harris, A. Epidermal-growth-factor receptor status as predictor of early recurrence of and death from breast cancer. Lancet 1987, 329, 1398-1402. [CrossRef]

20. Velu, T.; Beguinot, L.; Vass, W.; Willingham, M.; Merlino, G.; Pastan, I.; Lowy, D. Epidermal-growth-factordependent transformation by a human EGF receptor proto-oncogene. Science 1987, 238, 1408-1410. [CrossRef] [PubMed]

21. Di Fiore, P.P.; Pierce, J.H.; Fleming, T.P.; Hazan, R.; Ullrich, A.; King, C.R.; Schlessinger, J.; Aaronson, S.A. Overexpression of the human EGF receptor confers an EGF-dependent transformed phenotype to NIH 3T3 cells. Cell 1987, 51, 1063-1070. [CrossRef]

22. Lemmon, M.A.; Schlessinger, J. Cell signaling by receptor tyrosine kinases. Cell 2010, 141, 1117-1134. [CrossRef] [PubMed]

23. Tzahar, E.; Waterman, H.; Chen, X.; Levkowitz, G.; Karunagaran, D.; Lavi, S.; Ratzkin, B.J.; Yarden, Y. A hierarchical network of interreceptor interactions determines signal transduction by Neu differentiation factor/neuregulin and epidermal growth factor. Mol. Cell. Biol. 1996, 16, 5276-5287. [CrossRef] [PubMed]

24. Graus-Porta, D.; Beerli, R.R.; Daly, J.M.; Hynes, N.E. ErbB-2, the preferred heterodimerization partner of all ErbB receptors, is a mediator of lateral signaling. EMBO J. 1997, 16, 1647-1655. [CrossRef] [PubMed]

25. Holbro, T.; Beerli, R.R.; Maurer, F.; Koziczak, M.; Barbas, C.F.; Hynes, N.E. The ErbB2/ErbB3 heterodimer functions as an oncogenic unit: ErbB2 requires ErbB3 to drive breast tumor cell proliferation. Proc. Natl. Acad. Sci. USA 2003, 100, 8933-8938. [CrossRef] [PubMed]

26. Burgess, A.W.; Cho, H.S.; Eigenbrot, C.; Ferguson, K.M.; Garrett, T.P.J.; Leahy, D.J.; Lemmon, M.A.; Sliwkowski, M.X.; Ward, C.W.; Yokoyama, S.; et al. An Open-and-Shut Case? Recent Insights into the Activation of EGF/ErbB Receptors. Mol. Cell 2003, 12, 541-552. [CrossRef]

27. Tomas, A.; Futter, C.E.; Eden, E.R. EGF receptor trafficking: Consequences for signaling and cancer. Trends Cell Biol. 2014, 24, 26-34. [CrossRef] [PubMed]

28. Aroian, R.V.; Koga, M.; Mendel, J.E.; Ohshima, Y.; Sternberg, P.W. The let-23 gene necessary for Caenorhabditis elegans vulval induction encodes a tyrosine kinase of the EGF receptor subfamily. Nature 1990, 348, 693-699. [CrossRef] [PubMed]

29. Wasserman, J.D.; Freeman, M. Control of EGF receptor activation in Drosophila. Trends Cell Biol. 1997, 7, 431-436. [CrossRef]

30. Lusk, J.; Lam, V.; Tolwinski, N. Epidermal Growth Factor Pathway Signaling in Drosophila Embryogenesis: Tools for Understanding Cancer. Cancers 2017, 9, 16. [CrossRef] [PubMed]

31. Davies, R.L.; Grosse, V.A.; Kucherlapati, R.; Bothwell, M. Genetic analysis of epidermal growth factor action: Assignment of human epidermal growth factor receptor gene to chromosome 7. Proc. Natl. Acad. Sci. USA 1980, 77, 4188-4192. [CrossRef] [PubMed]

32. Kondo, I.; Shimizu, N. Mapping of the human gene for epidermal growth factor receptor (EGFR) on the p13 leads to q22 region of chromosome 7. Cytogenet. Cell Genet. 1983, 35, 9-14. [CrossRef] [PubMed]

33. Carpenter, G.; Cohen, S. Epidermal growth factor. Annu. Rev. Biochem. 1979, 48, 193-216. [CrossRef] [PubMed]

34. Gullick, W.J.; Marsden, J.J.; Whittle, N.; Ward, B.; Bobrow, L.; Waterfield, M.D. Expression of Epidermal Growth Factor Receptors on Human Cervical, Ovarian, and Vulval Carcinomas. Cancer Res. 1986, 46, $285-292$. [PubMed] 
35. Clark, A.J.; Ishii, S.; Richert, N.; Merlino, G.T.; Pastan, I. Epidermal growth factor regulates the expression of its own receptor. Proc. Natl. Acad. Sci. USA 1985, 82, 8374-8378. [CrossRef] [PubMed]

36. Kageyama, R.; Merlino, G.T.; Pastan, I. A transcription factor active on the epidermal growth factor receptor gene. Proc. Natl. Acad. Sci. USA 1988, 85, 5016-5020. [CrossRef] [PubMed]

37. Haley, J.; Whittle, N.; Bennet, P.; Kinchington, D.; Ullrich, A.; Waterfield, M. The human EGF receptor gene: Structure of the $110 \mathrm{~kb}$ locus and identification of sequences regulating its transcription. Oncogene Res. 1987, 1,375-396. [PubMed]

38. Johnson, A.C.; Ishii, S.; Jinno, Y.; Pastan, I.; Merlino, G.T. Epidermal growth factor receptor gene promoter. J. Biol. Chem. 1988, 263, 5693-5699. [PubMed]

39. Johnson, A.C. Activation of epidermal growth factor receptor gene transcription by phorbol 12-myristate 13-acetate is mediated by activator protein 2. J. Biol. Chem. 1996, 271, 3033-3038. [PubMed]

40. Mialon, A.; Sankinen, M.; Söderström, H.; Junttila, T.T.; Holmström, T.; Koivusalo, R.; Papageorgiou, A.C.; Johnson, R.S.; Hietanen, S.; Elenius, K.; et al. DNA topoisomerase I is a cofactor for c-Jun in the regulation of epidermal growth factor receptor expression and cancer cell proliferation. Mol. Cell. Biol. 2005, 25, 5040-5051. [CrossRef] [PubMed]

41. Fisher, D.A.; Lakshmanan, J. Metabolism and effects of epidermal growth factor and related growth factors in mammals. Endocr. Rev. 1990, 11, 418-442. [CrossRef] [PubMed]

42. Chia, C.M.; Winston, R.M.; Handyside, A.H. EGF, TGF-alpha and EGFR expression in human preimplantation embryos. Development 1995, 121, 299-307. [PubMed]

43. Roskoski, R. The ErbB/HER family of protein-tyrosine kinases and cancer. Pharmacol. Res. 2014, 79, 34-74. [CrossRef] [PubMed]

44. Olayioye, M.A.; Neve, R.M.; Lane, H.A.; Hynes, N.E. The ErbB signaling network: Receptor heterodimerization in development and cancer. EMBO J. 2000, 19, 3159-3167. [CrossRef] [PubMed]

45. Campbell, I.D.; Bork, P. Epidermal growth factor-like modules. Curr. Opin. Struct. Biol. 1993, 3, $385-392$. [CrossRef]

46. Threadgill, D.W.; Dlugosz, A.A.; Hansen, L.A.; Tennenbaum, T.; Lichti, U.; Yee, D.; LaMantia, C.; Mourton, T.; Herrup, K.; Harris, R.C.; et al. Targeted disruption of mouse EGF receptor: Effect of genetic background on mutant phenotype. Science 1995, 269, 230-234. [CrossRef] [PubMed]

47. Lee, K.F.; Simon, H.; Chen, H.; Bates, B.; Hung, M.C.; Hauser, C. Requirement for neuregulin receptor erbB2 in neural and cardiac development. Nature 1995, 378, 394-398. [CrossRef] [PubMed]

48. Morris, J.K.; Weichun, L.; Hauser, C.; Marchuk, Y.; Getman, D.; Kuo-Fen, L. Rescue of the cardiac defect in erbB2 mutant mice reveals essential roles of erbB2 in peripheral nervous system development. Neuron 1999, 23, 273-283. [CrossRef]

49. Lin, W.; Sanchez, H.B.; Deerinck, T.; Morris, J.K.; Ellisman, M.; Lee, K.F. Aberrant development of motor axons and neuromuscular synapses in erbB2-deficient mice. Proc. Natl. Acad. Sci. USA 2000, 97, 1299-1304. [CrossRef] [PubMed]

50. Erickson, S.L.; O'Shea, K.S.; Ghaboosi, N.; Loverro, L.; Frantz, G.; Bauer, M.; Lu, L.H.; Moore, M.W. ErbB3 is required for normal cerebellar and cardiac development: A comparison with ErbB2-and heregulin-deficient mice. Development 1997, 124, 4999-5011. [CrossRef] [PubMed]

51. Riethmacher, D.; Sonnenberg-Riethmacher, E.; Brinkmann, V.; Yamaai, T.; Lewin, G.R.; Birchmeier, C. Severe neuropathies in mice with targeted mutations in the ErbB3 receptor. Nature 1997, 389, 725-730. [CrossRef] [PubMed]

52. Golding, J.P.; Trainor, P.; Krumlauf, R.; Gassmann, M. Defects in pathfinding by cranial neural crest cells in mice lacking the Neuregulin receptor ErbB4. Nat. Cell Biol. 2000, 2, 103-109. [CrossRef] [PubMed]

53. Jones, F.E.; Golding, J.P.; Gassmann, M. ErbB4 signaling during breast and neural development: Novel genetic models reveal unique ErbB4 activities. Cell Cycle 2003, 2, 555-559. [CrossRef] [PubMed]

54. Gassmann, M.; Casagranda, F.; Orioli, D.; Simon, H.; Lai, C.; Klein, R.; Lemke, G. Aberrant neural and cardiac development in mice lacking the ErbB4 neuregulin receptor. Nature 1995, 378, 390-394. [CrossRef] [PubMed]

55. Green, M.R.; Basketter, D.A.; Couchman, J.R.; Rees, D.A. Distribution and number of epidermal growth factor receptors in skin is related to epithelial cell growth. Dev. Biol. 1983, 100, 506-512. [CrossRef]

56. Zieske, J.D.; Wasson, M. Regional variation in distribution of EGF receptor in developing and adult corneal epithelium. J. Cell Sci. 1993, 106 (Pt 1), 145-152. [PubMed] 
57. Fowler, K.J.; Walker, F.; Alexander, W.; Hibbs, M.L.; Nice, E.C.; Bohmer, R.M.; Mann, G.B.; Thumwood, C.; Maglitto, R.; Danks, J.A. A mutation in the epidermal growth factor receptor in waved-2 mice has a profound effect on receptor biochemistry that results in impaired lactation. Proc. Natl. Acad. Sci. USA 1995, 92, 1465-1469. [CrossRef] [PubMed]

58. Xie, W.; Paterson, A.J.; Chin, E.; Nabell, L.M.; Kudlow, J.E. Targeted expression of a dominant negative epidermal growth factor receptor in the mammary gland of transgenic mice inhibits pubertal mammary duct development. Mol. Endocrinol. 1997, 11, 1766-1781. [CrossRef] [PubMed]

59. Wiesen, J.F.; Young, P.; Werb, Z.; Cunha, G.R. Signaling through the stromal epidermal growth factor receptor is necessary for mammary ductal development. Development 1999, 126, 335-344. [PubMed]

60. Yamada, M.; Ikeuchi, T.; Hatanaka, H. The neurotrophic action and signalling of epidermal growth factor. Prog. Neurobiol. 1997, 51, 19-37. [CrossRef]

61. Liu, B.; Neufeld, A.H. Activation of epidermal growth factor receptors in astrocytes: From development to neural injury. J. Neurosci. Res. 2007, 85, 3523-3529. [CrossRef] [PubMed]

62. Gómez-Pinilla, F.; Knauer, D.J.; Nieto-Sampedro, M. Epidermal growth factor receptor immunoreactivity in rat brain. Development and cellular localization. Brain Res. 1988, 438, 385-390. [CrossRef]

63. Ciccolini, F.; Mandl, C.; Hölzl-Wenig, G.; Kehlenbach, A.; Hellwig, A. Prospective isolation of late development multipotent precursors whose migration is promoted by EGFR. Dev. Biol. 2005, 284, 112-125. [CrossRef] [PubMed]

64. Nieto-Sampedro, M.; Gomez-Pinilla, F.; Knauer, D.J.; Broderick, J.T. Epidermal growth factor receptor immunoreactivity in rat brain astrocytes. Response to injury. Neurosci. Lett. 1988, 91, 276-282. [CrossRef]

65. Carpenter, C.D.; Ingraham, H.A.; Cochet, C.; Walton, G.M.; Lazar, C.S.; Sowadski, J.M.; Rosenfeld, M.G.; Gill, G.N. Structural analysis of the transmembrane domain of the epidermal growth factor receptor. J. Biol. Chem. 1991, 266, 5750-5755. [PubMed]

66. Morrow, M.R.; Grant, C.W.M. The EGF receptor transmembrane domain: Peptide-peptide interactions in fluid bilayer membranes. Biophys. J. 2000, 79, 2024-2032. [CrossRef]

67. Cymer, F.; Schneider, D. Transmembrane helix-helix interactions involved in ErbB receptor signaling. Cell Adhes. Migr. 2010, 4, 299-312. [CrossRef]

68. Tanner, K.G.; Kyte, J. Dimerization of the extracellular domain of the receptor for epidermal growth factor containing the membrane-spanning segment in response to treatment with epidermal growth factor. J. Biol. Chem. 1999, 274, 35985-35990. [CrossRef] [PubMed]

69. Bell, C.A.; Tynan, J.A.; Hart, K.C.; Meyer, A.N.; Robertson, S.C.; Donoghue, D.J. Rotational coupling of the transmembrane and kinase domains of the Neu receptor tyrosine kinase. Mol. Biol Cell 2000, 11, 3589-3599. [CrossRef] [PubMed]

70. Walton, G.M.; Chen, W.S.; Rosenfeld, M.G.; Gill, G.N. Analysis of deletions of the carboxyl terminus of the epidermal growth factor receptor reveals self-phosphorylation at tyrosine 992 and enhanced in vivo tyrosine phosphorylation of cell substrates. J. Biol. Chem. 1990, 265, 1750-1754. [PubMed]

71. Stamos, J.; Sliwkowski, M.X.; Eigenbrot, C. Structure of the epidermal growth factor receptor kinase domain alone and in complex with a 4-anilinoquinazoline inhibitor. J. Biol. Chem. 2002, 277, 46265-46272. [CrossRef] [PubMed]

72. Zhang, X.; Gureasko, J.; Shen, K.; Cole, P.A.; Kuriyan, J. An Allosteric Mechanism for Activation of the Kinase Domain of Epidermal Growth Factor Receptor. Cell 2006, 125, 1137-1149. [CrossRef] [PubMed]

73. Lee, J.C.; Vivanco, I.; Beroukhim, R.; Huang, J.H.Y.; Feng, W.L.; DeBiasi, R.M.; Yoshimoto, K.; King, J.C.; Nghiemphu, P.; Yuza, Y.; et al. Epidermal growth factor receptor activation in glioblastoma through novel missense mutations in the extracellular domain. PLoS Med. 2006, 3, e485. [CrossRef] [PubMed]

74. Barber, T.D.; Vogelstein, B.; Kinzler, K.W.; Velculescu, V.E. Somatic Mutations of EGFR in Colorectal Cancers and Glioblastomas. N. Engl. J. Med. 2004, 351, 2883. [CrossRef] [PubMed]

75. Cappuzzo, F.; Finocchiaro, G.; Rossi, E.; Jänne, P.A.; Carnaghi, C.; Calandri, C.; Bencardino, K.; Ligorio, C.; Ciardiello, F.; Pressiani, T.; et al. EGFR FISH assay predicts for response to cetuximab in chemotherapy refractory colorectal cancer patients. Ann. Oncol. 2008, 19, 717-723. [CrossRef] [PubMed]

76. Fujino, S.; Enokibori, T.; Tezuka, N.; Asada, Y.; Inoue, S.; Kato, H.; Mori, A. A comparison of epidermal growth factor receptor levels and other prognostic parameters in non-small cell lung cancer. Eur. J. Cancer 1996, 32, 2070-2074. [CrossRef] 
77. Endres, N.F.; Barros, T.; Cantor, A.J.; Kuriyan, J. Emerging concepts in the regulation of the EGF receptor and other receptor tyrosine kinases. Trends Biochem. Sci. 2014, 39, 437-446. [CrossRef] [PubMed]

78. Red Brewer, M.; Yun, C.-H.; Lai, D.; Lemmon, M.A.; Eck, M.J.; Pao, W. Mechanism for activation of mutated epidermal growth factor receptors in lung cancer. Proc. Natl. Acad. Sci. USA 2013, 110, E3595-E3604. [CrossRef] [PubMed]

79. Gan, H.K.; Cvrljevic, A.N.; Johns, T.G. The epidermal growth factor receptor variant III (EGFRvIII): Where wild things are altered. FEBS J. 2013, 280, 5350-5370. [CrossRef] [PubMed]

80. Schmidt, M.H.H.; Furnari, F.B.; Cavenee, W.K.; Bögler, O. Epidermal growth factor receptor signaling intensity determines intracellular protein interactions, ubiquitination, and internalization. Proc. Natl. Acad. Sci. USA 2003, 100, 6505-6510. [CrossRef] [PubMed]

81. Paez, J.G.; Jänne, P.A.; Lee, J.C.; Tracy, S.; Greulich, H.; Gabriel, S.; Herman, P.; Kaye, F.J.; Lindeman, N.; Boggon, T.J.; et al. EGFR mutations in lung cancer: Correlation with clinical response to gefitinib therapy. Science 2004, 304, 1497-1500. [CrossRef] [PubMed]

82. Shigematsu, H.; Lin, L.; Takahashi, T.; Nomura, M.; Suzuki, M.; Wistuba, I.I.; Fong, K.M.; Lee, H.; Toyooka, S.; Shimizu, N.; et al. Clinical and biological features associated with epidermal growth factor receptor gene mutations in lung cancers. J. Natl. Cancer Inst. 2005, 97, 339-346. [CrossRef] [PubMed]

83. Carey, K.D.; Garton, A.J.; Romero, M.S.; Kahler, J.; Thomson, S.; Ross, S.; Park, F.; Haley, J.D.; Gibson, N.; Sliwkowski, M.X. Kinetic analysis of epidermal growth factor receptor somatic mutant proteins shows increased sensitivity to the epidermal growth factor receptor tyrosine kinase inhibitor, erlotinib. Cancer Res. 2006, 66, 8163-8171. [CrossRef] [PubMed]

84. Yun, C.H.; Boggon, T.J.; Li, Y.; Woo, M.S.; Greulich, H.; Meyerson, M.; Eck, M.J. Structures of Lung Cancer-Derived EGFR Mutants and Inhibitor Complexes: Mechanism of Activation and Insights into Differential Inhibitor Sensitivity. Cancer Cell 2007, 11, 217-227. [CrossRef] [PubMed]

85. Kumar, A.; Petri, E.T.; Halmos, B.; Boggon, T.J. Structure and clinical relevance of the epidermal growth factor receptor in human cancer. J. Clin. Oncol. 2008, 26, 1742-1751. [CrossRef] [PubMed]

86. Yasuda, H.; Park, E.; Yun, C.-H.; Sng, N.J.; Lucena-Araujo, A.R.; Yeo, W.-L.; Huberman, M.S.; Cohen, D.W.; Nakayama, S.; Ishioka, K.; et al. Structural, biochemical, and clinical characterization of epidermal growth factor receptor (EGFR) exon 20 insertion mutations in lung cancer. Sci. Transl. Med. 2013, 5, 216 ra177. [CrossRef] [PubMed]

87. Zhang, Z.; Stiegler, A.L.; Boggon, T.J.; Kobayashi, S.; Halmos, B. EGFR-mutated lung cancer: A paradigm of molecular oncology. Oncotarget 2010, 1, 497-514. [CrossRef] [PubMed]

88. Yun, C.-H.; Mengwasser, K.E.; Toms, A.V.; Woo, M.S.; Greulich, H.; Wong, K.-K.; Meyerson, M.; Eck, M.J. The T790M mutation in EGFR kinase causes drug resistance by increasing the affinity for ATP. Proc. Natl. Acad. Sci. USA 2008, 105, 2070-2075. [CrossRef] [PubMed]

89. Inukai, M.; Toyooka, S.; Ito, S.; Asano, H.; Ichihara, S.; Soh, J.; Suehisa, H.; Ouchida, M.; Aoe, K.; Aoe, M.; et al. Presence of epidermal growth factor receptor gene T790M mutation as a minor clone in non-small cell lung cancer. Cancer Res. 2006, 66, 7854-7858. [CrossRef] [PubMed]

90. Olsen, J.V.; Blagoev, B.; Gnad, F.; Macek, B.; Kumar, C.; Mortensen, P.; Mann, M. Global, In Vivo, and Site-Specific Phosphorylation Dynamics in Signaling Networks. Cell 2006, 127, 635-648. [CrossRef] [PubMed]

91. Waters, K.M.; Liu, T.; Quesenberry, R.D.; Willse, A.R.; Bandyopadhyay, S.; Kathmann, L.E.; Weber, T.J.; Smith, R.D.; Wiley, H.S.; Thrall, B.D. Network analysis of epidermal growth factor signaling using integrated genomic, proteomic and phosphorylation data. PLoS ONE 2012, 7, e34515. [CrossRef] [PubMed]

92. Oda, K.; Matsuoka, Y.; Funahashi, A.; Kitano, H. A comprehensive pathway map of epidermal growth factor receptor signaling. Mol. Syst. Biol. 2005, 1, 2005.0010. [CrossRef] [PubMed]

93. Conte, A.; Sigismund, S. The Ubiquitin Network in the Control of EGFR Endocytosis and Signaling. Prog. Mol. Biol. Transl. Sci. 2016. [CrossRef]

94. Sigismund, S.; Woelk, T.; Puri, C.; Maspero, E.; Tacchetti, C.; Transidico, P.; Di Fiore, P.P.; Polo, S. Clathrin-independent endocytosis of ubiquitinated cargos. Proc. Natl. Acad. Sci. USA 2005, 102, 2760-2765. [CrossRef] [PubMed]

95. Kasselberg, A.G.; Orth, D.N.; Gray, M.E.; Stahlman, M.T. Immunocytochemical localization of human epidermal growth factor/urogastrone in several human tissues. J. Histochem. Cytochem. 1985, 33, 315-322. [CrossRef] [PubMed] 
96. Edwin, F.; Wiepz, G.J.; Singh, R.; Peet, C.R.; Chaturvedi, D.; Bertics, P.J.; Patel, T.B. A historical perspective of the EGF receptor and related systems. Methods Mol. Biol. 2006, 327, 1-24. [CrossRef] [PubMed]

97. Singh, A.B.; Harris, R.C. Autocrine, paracrine and juxtacrine signaling by EGFR ligands. Cell Signal. 2005, 17, 1183-1193. [CrossRef] [PubMed]

98. Singh, B.; Carpenter, G.; Coffey, R.J. EGF receptor ligands: Recent advances. F1000Research 2016, 5, 2270. [CrossRef] [PubMed]

99. Normanno, N.; De Luca, A.; Bianco, C.; Strizzi, L.; Mancino, M.; Maiello, M.R.; Carotenuto, A.; De Feo, G.; Caponigro, F.; Salomon, D.S. Epidermal growth factor receptor (EGFR) signaling in cancer. Gene 2006, 366, 2-16. [CrossRef] [PubMed]

100. Carraway, K.L.; Weber, J.L.; Unger, M.J.; Ledesma, J.; Yu, N.; Gassmann, M.; Lai, C. Neuregulin-2, a new ligand of ErbB3/ErbB4-receptor tyrosine kinases. Nature 1997, 387, 512-516. [CrossRef] [PubMed]

101. Chang, H.; Riese, D.J.; Gilbert, W.; Stern, D.F.; McMahan, U.J. Ligands for ErbB-family receptors encoded by a neuregulin-like gene. Nature 1997, 387, 509-512. [CrossRef] [PubMed]

102. Wheeler, D.L.; Dunn, E.F.; Harari, P.M. Understanding resistance to EGFR inhibitors-impact on future treatment strategies. Nat. Rev. Clin. Oncol. 2010, 7, 493-507. [CrossRef] [PubMed]

103. Zhang, D.; Sliwkowski, M.X.; Mark, M.; Frantz, G.; Akita, R.; Sun, Y.; Hillan, K.; Crowley, C.; Brush, J.; Godowski, P.J. Neuregulin-3 (NRG3): A novel neural tissue-enriched protein that binds and activates ErbB4. Proc. Natl. Acad. Sci. USA 1997, 94, 9562-9567. [CrossRef] [PubMed]

104. Roepstorff, K.; Grandal, M.V.; Henriksen, L.; Knudsen, S.L.J.; Lerdrup, M.; Grøvdal, L.; Willumsen, B.M.; Van Deurs, B. Differential effects of EGFR ligands on endocytic sorting of the receptor. Traffic 2009, 10, 1115-1127. [CrossRef] [PubMed]

105. Sweeney, C.; Fambrough, D.; Huard, C.; Diamonti, A.J.; Lander, E.S.; Cantley, L.C.; Carraway, K.L. Growth Factor-specific Signaling Pathway Stimulation and Gene Expression Mediated by ErbB Receptors. J. Biol. Chem. 2001, 276, 22685-22698. [CrossRef] [PubMed]

106. Ebner, R.; Derynck, R. Epidermal growth factor and transforming growth factor-alpha: Differential intracellular routing and processing of ligand-receptor complexes. Cell Regul. 1991, 2, 599-612. [CrossRef] [PubMed]

107. French, A.R.; Tadaki, D.K.; Niyogi, S.K.; Lauffenburger, D.A. Intracellular trafficking of epidermal growth factor family ligands is directly influenced by the $\mathrm{pH}$ sensitivity of the receptor/ligand interaction. J. Biol. Chem. 1995, 270, 4334-4340. [CrossRef] [PubMed]

108. Waterman, H.; Sabanai, I.; Geiger, B.; Yarden, Y. Alternative intracellular routing of ErbB receptors may determine signaling potency. J. Biol. Chem. 1998, 273, 13819-13827. [CrossRef] [PubMed]

109. Wilson, K.J.; Gilmore, J.L.; Foley, J.; Lemmon, M.A.; Riese, D.J. Functional selectivity of EGF family peptide growth factors: Implications for cancer. Pharmacol. Ther. 2009, 122, 1-8. [CrossRef] [PubMed]

110. Sporn, M.B.; Roberts, A.B. Autocrine growth factors and cancer. Nature 1985, 313, 745-747. [CrossRef] [PubMed]

111. De Larco, J.E.; Todaro, G.J. Growth factors from murine sarcoma virus-transformed cells. Proc. Natl. Acad. Sci. USA 1978, 75, 4001-4005. [CrossRef] [PubMed]

112. Yarden, Y.; Schlessinger, J. Epidermal growth factor induces rapid, reversible aggregation of the purified epidermal growth factor receptor. Biochemistry 1987, 26, 1443-1451. [CrossRef] [PubMed]

113. Yarden, Y.; Schlessinger, J. Self-phosphorylation of epidermal growth factor receptor: Evidence for a model of intermolecular allosteric activation. Biochemistry 1987, 26, 1434-1442. [CrossRef] [PubMed]

114. Ferguson, K.M.; Berger, M.B.; Mendrola, J.M.; Cho, H.S.; Leahy, D.J.; Lemmon, M.A. EGF activates its receptor by removing interactions that autoinhibit ectodomain dimerization. Mol. Cell 2003, 11, 507-517. [CrossRef]

115. Jura, N.; Endres, N.F.; Engel, K.; Deindl, S.; Das, R.; Lamers, M.H.; Wemmer, D.E.; Zhang, X.; Kuriyan, J. Mechanism for Activation of the EGF Receptor Catalytic Domain by the Juxtamembrane Segment. Cell 2009, 137, 1293-1307. [CrossRef] [PubMed]

116. Clayton, A.H.A.; Walker, F.; Orchard, S.G.; Henderson, C.; Fuchs, D.; Rothacker, J.; Rothacker, J.; Nice, E.C.; Burgess, A.W. Ligand-induced dimer-tetramer transition during the activation of the cell surface epidermal growth factor receptor-A multidimensional microscopy analysis. J. Biol. Chem. 2005, 280, 30392-30399. [CrossRef] [PubMed] 
117. Gadella, T.W.; Jovin, T.M. Oligomerization of epidermal growth factor receptors on A431 cells studied by time-resolved fluorescence imaging microscopy. A stereochemical model for tyrosine kinase receptor activation. J. Cell Biol. 1995, 129, 1543-1558. [CrossRef] [PubMed]

118. Tao, R.-H.; Maruyama, I.N. All EGF(ErbB) receptors have preformed homo- and heterodimeric structures in living cells. J. Cell Sci. 2008, 121, 3207-3217. [CrossRef] [PubMed]

119. Chung, I.; Akita, R.; Vandlen, R.; Toomre, D.; Schlessinger, J.; Mellman, I. Spatial control of EGF receptor activation by reversible dimerization on living cells. Nature 2010, 464, 783-787. [CrossRef] [PubMed]

120. Bessman, N.J.; Bagchi, A.; Ferguson, K.M.; Lemmon, M.A. Complex Relationship between Ligand Binding and Dimerization in the Epidermal Growth Factor Receptor. Cell Rep. 2014, 9, 1306-1317. [CrossRef] [PubMed]

121. Lu, C.; Mi, L.Z.; Schürpf, T.; Walz, T.; Springer, T.A. Mechanisms for kinase-mediated dimerization of the epidermal growth factor receptor. J. Biol. Chem. 2012, 287, 38244-38253. [CrossRef] [PubMed]

122. Li, E.; Hristova, K. Receptor tyrosine kinase transmembrane domains: Function, dimer structure and dimerization energetics. Cell Adhes. Migr. 2010, 4, 249-254. [CrossRef]

123. Sato, K.-I. Cellular Functions Regulated by Phosphorylation of EGFR on Tyr845. Int. J. Mol. Sci. 2013, 14, 10761-10790. [CrossRef] [PubMed]

124. Hunter, T.; Ling, N.; Cooper, J.A. Protein kinase C phosphorylation of the EGF receptor at a threonine residue close to the cytoplasmic face of the plasma membrane. Nature 1984, 311, 480-483. [CrossRef] [PubMed]

125. Pawson, T. Specificity in Signal Transduction: From Phosphotyrosine-SH2 Domain Interactions to Complex Cellular Systems. Cell 2004, 116, 191-203. [CrossRef]

126. Morrison, D.K. MAP Kinase Pathways. Cold Spring Harb. Perspect. Biol. 2012, 4, a011254. [CrossRef] [PubMed]

127. Lewis, T.S.; Shapiro, P.S.; Ahn, N.G. Signal Transduction through MAP Kinase Cascades. Adv. Cancer Res. 1998, 74, 49-139. [CrossRef] [PubMed]

128. Lowenstein, E.J.; Daly, R.J.; Batzer, A.G.; Li, W.; Margolis, B.; Lammers, R.; Ullrich, A.; Skolnik, E.Y.; Bar-Sagi, D.; Schlessinger, J. The SH2 and SH3 domain-containing protein GRB2 links receptor tyrosine kinases to ras signaling. Cell 1992, 70, 431-442. [CrossRef]

129. Buday, L.; Downward, J. Epidermal growth factor regulates p21ras through the formation of a complex of receptor, Grb2 adapter protein, and Sos nucleotide exchange factor. Cell 1993, 73, 611-620. [CrossRef]

130. Jiang, X.; Huang, F.; Marusyk, A.; Sorkin, A. Grb2 regulates internalization of EGF receptors through clathrin-coated pits. Mol. Biol Cell 2003, 14, 858-870. [CrossRef] [PubMed]

131. Batzer, A.G.; Rotin, D.; Ureña, J.M.; Skolnik, E.Y.; Schlessinger, J. Hierarchy of binding sites for Grb2 and Shc on the epidermal growth factor receptor. Mol. Cell. Biol. 1994, 14, 5192-5201. [CrossRef] [PubMed]

132. Pelicci, G.; Lanfrancone, L.; Grignani, F.; McGlade, J.; Cavallo, F.; Forni, G.; Nicoletti, I.; Grignani, F.; Pawson, T.; Giuseppe Pelicci, P. A novel transforming protein (SHC) with an SH2 domain is implicated in mitogenic signal transduction. Cell 1992, 70, 93-104. [CrossRef]

133. Okabayashi, Y.; Kido, Y.; Okutani, T.; Sugimoto, Y.; Sakaguchi, K.; Kasuga, M. Tyrosines 1148 and 1173 of activated human epidermal growth factor receptors are binding sites of Shc in intact cells. J. Biol. Chem. 1994, 269, 18674-18678. [PubMed]

134. Sakaguchi, K.; Okabayashi, Y.; Kido, Y.; Kimura, S.; Matsumura, Y.; Inushima, K.; Kasuga, M. Shc phosphotyrosine-binding domain dominantly interacts with epidermal growth factor receptors and mediates Ras activation in intact cells. Mol. Endocrinol. 1998, 12, 536-543. [CrossRef] [PubMed]

135. Salcini, A.E.; McGlade, J.; Pelicci, G.; Nicoletti, I.; Pawson, T.; Pelicci, P.G. Formation of Shc-Grb2 complexes is necessary to induce neoplastic transformation by overexpression of Shc proteins. Oncogene 1994, 9, 2827-2836. [PubMed]

136. Van der Geer, P.; Wiley, S.; Ka-Man Lai, V.; Olivier, J.P.; Gish, G.D.; Stephens, R.; Kaplan, D.; Shoelson, S.; Pawson, T. A conserved amino-terminal Shc domain binds to phosphotyrosine motifs in activated receptors and phosphopeptides. Curr. Biol. 1995, 5, 404-412. [CrossRef]

137. Chardin, P.; Camonis, J.H.; Gale, N.W.; van Aelst, L.; Schlessinger, J.; Wigler, M.H.; Bar-Sagi, D. Human Sos1: A guanine nucleotide exchange factor for Ras that binds to GRB2. Science 1993, 260, 1338-1343. [CrossRef] [PubMed]

138. Li, N.; Batzer, A.; Daly, R.; Yajnik, V.; Skolnik, E.; Chardin, P.; Bar-Sagi, D.; Margolis, B.; Schlessinger, J. Guanine-nucleotide-releasing factor hSos1 binds to Grb2 and links receptor tyrosine kinases to Ras signalling. Nature 1993, 363, 85-88. [CrossRef] [PubMed] 
139. Egan, S.E.; Giddings, B.W.; Brooks, M.W.; Buday, L.; Sizeland, A.M.; Weinberg, R.A. Association of Sos Ras exchange protein with Grb2 is implicated in tyrosine kinase signal transduction and transformation. Nature 1993, 363, 45-51. [CrossRef] [PubMed]

140. Rozakis-Adcock, M.; Fernley, R.; Wade, J.; Pawson, T.; Bowtell, D. The SH2 and SH3 domains of mammalian Grb2 couple the EGF receptor to the Ras activator mSos1. Nature 1993, 363, 83-85. [CrossRef] [PubMed]

141. Simon, J.A.; Schreiber, S.L. Grb2 SH3 binding to peptides from Sos: Evaluation of a general model for SH3-ligand interactions. Chem. Biol. 1995, 2, 53-60. [CrossRef]

142. Boriack-Sjodin, P.A.; Margarit, S.M.; Bar-Sagi, D.; Kuriyan, J. The structural basis of the activation of Ras by Sos. Nature 1998, 394, 337-343. [CrossRef] [PubMed]

143. Brtva, T.R.; Drugan, J.K.; Ghosh, S.; Terrell, R.S.; Campbell-Burk, S.; Bell, R.M.; Der, C.J. Two distinct Raf domains mediate interaction with Ras. J. Biol. Chem. 1995, 270, 9809-9812. [CrossRef] [PubMed]

144. Xiang, X.; Zang, M.; Waelde, C.A.; Wen, R.; Luo, Z. Phosphorylation of 338SSYY341 regulates specific interaction between Raf-1 and MEK1. J. Biol. Chem. 2002, 277, 44996-45003. [CrossRef] [PubMed]

145. Zang, M.; Gong, J.; Luo, L.; Zhou, J.; Xiang, X.; Huang, W.; Luo, X.; Olbrot, M.; Peng, Y.; Chen, C.; et al. Characterization of Ser338 phosphorylation for Raf-1 activation. J. Biol. Chem. 2008, 283, 31429-31437. [CrossRef] [PubMed]

146. Diaz, B.; Barnard, D.; Filson, A. Phosphorylation of Raf-1 serine 338-serine 339 is an essential regulatory event for Ras-dependent activation and biological signaling. Mol. Cell. Biol. 1997, 17, 4509-4516. [CrossRef] [PubMed]

147. Fabian, J.R.; Daar, I.O.; Morrison, D.K. Critical tyrosine residues regulate the enzymatic and biological activity of Raf-1 kinase. Mol. Cell. Biol. 1993, 13, 7170-7179. [CrossRef] [PubMed]

148. Bondzi, C.; Grant, S.; Krystal, G.W. A novel assay for the measurement of Raf-1 kinase activity. Oncogene 2000, 19, 5030-5033. [CrossRef] [PubMed]

149. Dhanasekaran, N.; Premkumar Reddy, E. Signaling by dual specificity kinases. Oncogene 1998, 17, 1447-1455. [CrossRef] [PubMed]

150. Sasaoka, T.; Langlois, W.J.; Leitner, J.W.; Draznin, B.; Olefsky, J.M. The Signaling Pathway Coupling Epidermal Growth Factor Receptors to Activation of p21ras. J. Biol. Chem. 1994, 269, 32621-32625. [PubMed]

151. Lanzerstorfer, P.; Borgmann, D.; Schütz, G.; Winkler, S.M.; Höglinger, O.; Weghuber, J. Quantification and kinetic analysis of Grb2-EGFR interaction on micro-patterned surfaces for the characterization of EGFR-modulating substances. PLoS ONE 2014, 9, e92151. [CrossRef] [PubMed]

152. Lee, C.S.; Kim, I.S.; Park, J.B.; Lee, M.N.; Lee, H.Y.; Suh, P.-G.; Ryu, S.H. The phox homology domain of phospholipase D activates dynamin GTPase activity and accelerates EGFR endocytosis. Nat. Cell Biol. 2006, 8, 477-484. [CrossRef] [PubMed]

153. Zhao, C.; Du, G.; Skowronek, K.; Frohman, M.A.; Bar-Sagi, D. Phospholipase D2-generated phosphatidic acid couples EGFR stimulation to Ras activation by Sos. Nat. Cell Biol. 2007, 9, 706-712. [CrossRef] [PubMed]

154. Soubeyran, P.; Kowanetz, K.; Szymkiewicz, I.; Langdon, W.Y.; Dikic, I. Cbl-CIN85-endophilin complex mediates ligand-induced downregulation of EGF receptors. Nature 2002, 416, 183-187. [CrossRef] [PubMed]

155. Waterman, H.; Katz, M.; Rubin, C.; Shtiegman, K.; Lavi, S.; Elson, A.; Jovin, T.; Yarden, Y. A mutant EGF-receptor defective in ubiquitylation and endocytosis unveils a role for Grb2 in negative signaling. EMBO J. 2002, 21, 303-313. [CrossRef] [PubMed]

156. Fukazawa, T.; Miyake, S.; Band, V.; Band, H. Tyrosine phosphorylation of Cbl upon epidermal growth factor (EGF) stimulation and its association with EGF receptor and downstream signaling proteins. J. Biol. Chem. 1996, 271, 14554-14559. [CrossRef] [PubMed]

157. Sigismund, S.; Algisi, V.; Nappo, G.; Conte, A.; Pascolutti, R.; Cuomo, A.; Bonaldi, T.; Argenzio, E.; Verhoef, L.G.G.C.; Maspero, E.; et al. Threshold-controlled ubiquitination of the EGFR directs receptor fate. EMBO J. 2013, 32, 2140-2157. [CrossRef] [PubMed]

158. Gureasko, J.; Galush, W.J.; Boykevisch, S.; Sondermann, H.; Bar-Sagi, D.; Groves, J.T.; Kuriyan, J. Membrane-dependent signal integration by the Ras activator Son of sevenless. Nat. Struct. Mol. Biol. 2008, 15, 452-461. [CrossRef] [PubMed]

159. Kim, M.J.; Chang, J.S.; Park, S.K.; Hwang, J.I.; Ryu, S.H.; Suh, P.G. Direct interaction of SOS1 Ras exchange protein with the SH3 domain of phospholipase C- $\gamma 1$. Biochemistry 2000, 39, 8674-8682. [CrossRef] [PubMed]

160. Maertens, O.; Cichowski, K. An expanding role for RAS GTPase activating proteins (RAS GAPs) in cancer. Adv. Biol. Regul. 2014, 55, 1-14. [CrossRef] [PubMed] 
161. Bunda, S.; Heir, P.; Srikumar, T.; Cook, J.D.; Burrell, K.; Kano, Y.; Lee, J.E.; Zadeh, G.; Raught, B.; Ohh, M. Src promotes GTPase activity of Ras via tyrosine 32 phosphorylation. Proc. Natl. Acad. Sci. USA 2014, 111, E3785-E3794. [CrossRef] [PubMed]

162. Bunda, S.; Burrell, K.; Heir, P.; Zeng, L.; Alamsahebpour, A.; Kano, Y.; Raught, B.; Zhang, Z.-Y.; Zadeh, G.; Ohh, M. Inhibition of SHP2-mediated dephosphorylation of Ras suppresses oncogenesis. Nat. Commun. 2015, 6, 8859. [CrossRef] [PubMed]

163. Kano, Y.; Cook, J.D.; Lee, J.E.; Ohh, M. New structural and functional insight into the regulation of Ras. Semin. Cell Dev. Biol. 2016, 58, 70-78. [CrossRef] [PubMed]

164. Findlay, G.M.; Pawson, T. How is SOS activated? Let us count the ways. Nat. Struct. Mol. Biol. 2008, 15, 538-540. [CrossRef] [PubMed]

165. Hofer, F.; Fields, S.; Schneider, C.; Martin, G.S. Activated Ras interacts with the Ral guanine nucleotide dissociation stimulator. Proc. Natl. Acad. Sci. USA 1994, 91, 11089-11093. [CrossRef] [PubMed]

166. Rodriguez-Viciana, P.; Warne, P.H.; Dhand, R.; Vanhaesebroeck, B.; Gout, I.; Fry, M.J.; Waterfield, M.D.; Downward, J. Phosphatidylinositol-3-OH kinase as a direct target of Ras. Nature 1994, 370, 527-532. [CrossRef] [PubMed]

167. Fernández-Medarde, A.; Santos, E. Ras in cancer and developmental diseases. Genes Cancer 2011, 2, 344-358. [CrossRef] [PubMed]

168. Hallberg, B.; Rayter, S.I.; Downward, J. Interaction of Ras and Raf in intact mammalian cells upon extracellular stimulation. J. Biol. Chem. 1994, 269, 3913-3916. [PubMed]

169. O'Neill, A.K.; Niederst, M.J.; Newton, A.C. Suppression of survival signalling pathways by the phosphatase PHLPP. FEBS J. 2013, 280, 572-583. [CrossRef] [PubMed]

170. Garcia-Rendueles, M.E.R.; Ricarte-Filho, J.C.; Untch, B.R.; Landa, I.; Knauf, J.A.; Voza, F.; Smith, V.E.; Ganly, I.; Taylor, B.S.; Persaud, Y.; et al. NF2 loss promotes oncogenic RAS-induced thyroid cancers via YAP-dependent transactivation of RAS proteins and sensitizes them to MEK inhibition. Cancer Discov. 2015, 5, 1178-1193. [CrossRef] [PubMed]

171. Hu, C.D.; Kariya, K.I.; Tamada, M.; Akasaka, K.; Shirouzu, M.; Yokoyama, S.; Kataoka, T. Cysteine-rich region of Raf-1 interacts with activator domain of post-translationally modified Ha-Ras. J. Biol. Chem. 1995, 270, 30274-30277. [CrossRef] [PubMed]

172. Hu, C.D.; Kariya, K.I.; Kotani, G.; Shirouzu, M.; Yokoyama, S.; Kataoka, T. Coassociation of Rap1A and Ha-Ras with Raf-1 N-terminal region interferes with Ras-dependent activation of Raf-1. J. Biol. Chem. 1997, 272, 11702-11705. [CrossRef] [PubMed]

173. Luo, Z.; Diaz, B.; Marshall, M.S.; Avruch, J. An intact Raf zinc finger is required for optimal binding to processed Ras and for ras-dependent Raf activation in situ. Mol. Cell. Biol. 1997, 17, 46-53. [CrossRef] [PubMed]

174. Roy, S.; Lane, A.; Yan, J.; McPherson, R.; Hancock, J.F. Activity of plasma membrane-recruited Raf-1 is regulated by Ras via the Raf zinc finger. J. Biol. Chem. 1997, 272, 20139-20145. [CrossRef] [PubMed]

175. Dhillon, A.S.; Kolch, W. Untying the regulation of the Raf-1 kinase. Arch. Biochem. Biophys. 2002, 404, 3-9. [CrossRef]

176. Davies, H.; Bignell, G.R.; Cox, C.; Stephens, P.; Edkins, S.; Clegg, S.; Teague, J.; Woffendin, H.; Futreal, P.A. Mutations of the BRAF gene in human cancer. Nature 2002, 417, 949-954. [CrossRef] [PubMed]

177. Garnett, M.J.; Marais, R. Guilty as charged: B-RAF is a human oncogene. Cancer Cell 2004, 6, 313-319. [CrossRef] [PubMed]

178. Marais, R.; Marshall, C.J. Control of the ERK MAP kinase cascade by Ras and Raf. Cancer Surv. 1996, 27, 101-125. [PubMed]

179. Mason, C.S.; Springer, C.J.; Cooper, R.G.; Superti-Furga, G.; Marshall, C.J.; Marais, R. Serine and tyrosine phosphorylations cooperate in Raf-1, but not B-Raf activation. EMBO J. 1999, 18, 2137-2148. [CrossRef] [PubMed]

180. King, A.J.; Sun, H.; Diaz, B.; Barnard, D.; Miao, W.; Bagrodia, S.; Marshall, M.S. The protein kinase Pak3 positively regulates Raf-1 activity through phosphorylation of serine 338. Nature 1998, 396, 180-183. [CrossRef] [PubMed]

181. Chiloeches, A.; Mason, C.S.; Marais, R. S338 phosphorylation of Raf-1 is independent of phosphatidylinositol 3-kinase and Pak3. Mol. Cell. Biol. 2001, 21, 2423-2434. [CrossRef] [PubMed] 
182. Frost, J.A.; Steen, H.; Shapiro, P.; Lewis, T.; Ahn, N.; Shaw, P.E.; Cobb, M.H. Cross-cascade activation of ERKs and ternary complex factors by Rho family proteins. EMBO J. 1997, 16, 6426-6438. [CrossRef] [PubMed]

183. Slack-Davis, J.K.; Eblen, S.T.; Zecevic, M.; Boerner, S.A.; Tarcsafalvi, A.; Diaz, H.B.; Marshall, M.S.; Weber, M.J.; Parsons, J.T.; Catling, A.D. PAK1 phosphorylation of MEK1 regulates fibronectin-stimulated MAPK activation. J. Cell Biol. 2003, 162, 281-291. [CrossRef] [PubMed]

184. Chaudhary, A.; King, W.G.; Mattaliano, M.D.; Frost, J.A.; Diaz, B.; Morrison, D.K.; Cobb, M.H.; Marshall, M.S.; Brugge, J.S. Phosphatidylinositol 3-kinase regulates Raf1 through Pak phosphorylation of serine 338. Curr. Biol. 2000, 10, 551-554. [CrossRef]

185. Zhu, J.; Balan, V.; Bronisz, A.; Balan, K.; Sun, H.; Leicht, D.T.; Luo, Z.; Qin, J.; Avruch, J.; Tzivion, G. Identification of Raf-1 S471 as a novel phosphorylation site critical for Raf-1 and B-Raf kinase activities and for MEK binding. Mol. Biol Cell 2005, 16, 4733-4744. [CrossRef] [PubMed]

186. Chong, H.; Lee, J.; Guan, K.L. Positive and negative regulation of Raf kinase activity and function by phosphorylation. EMBO J. 2001, 20, 3716-3727. [CrossRef] [PubMed]

187. Michaud, N.R.; Fabian, J.R.; Mathes, K.D.; Morrison, D.K. 14-3-3 is not essential for Raf-1 function: Identification of Raf-1 proteins that are biologically activated in a 14-3-3- and Ras-independent manner. Mol. Cell. Biol. 1995, 15, 3390-3397. [CrossRef] [PubMed]

188. Muslin, A.J.; Tanner, J.W.; Allen, P.M.; Shaw, A.S. Interaction of 14-3-3 with signaling proteins is mediated by the recognition of phosphoserine. Cell 1996, 84, 889-897. [CrossRef]

189. Zimmermann, S.; Moelling, K. Phosphorylation and regulation of Raf by Akt (protein kinase B). Science 1999, 286, 1741-1744. [CrossRef] [PubMed]

190. Roy, S.; McPherson, R.A.; Apolloni, A.; Yan, J.; Lane, A.; Clyde-Smith, J. 14-3-3 Facilitates Ras-Dependent Raf-1 Activation In Vitro and In Vivo 14-3-3 Facilitates Ras-Dependent Raf-1 Activation In Vitro and In Vivo. Mol. Cell. Biol. 1998, 18, 3947-3955. [CrossRef] [PubMed]

191. Rommel, C.; Radziwill, G.; Lovrić, J.; Noeldeke, J.; Heinicke, T.; Jones, D.; Aitken, A.; Moelling, K. Activated Ras displaces 14-3-3 protein from the amino terminus of c-Raf-1. Oncogene 1996, 12, 609-619. [PubMed]

192. Kubicek, M.; Pacher, M.; Abraham, D.; Podar, K.; Eulitz, M.; Baccarini, M. Dephosphorylation of Ser-259 regulates Raf-1 membrane association. J. Biol. Chem. 2002, 277, 7913-7919. [CrossRef] [PubMed]

193. Abraham, D.; Podar, K.; Pacher, M.; Kubicek, M.; Welzel, N.; Hemmings, B.A.; Dilworth, S.M.; Mischak, H.; Kolch, W.; Baccarini, M. Raf-1-associated protein phosphatase $2 \mathrm{~A}$ as a positive regulator of kinase activation. J. Biol. Chem. 2000, 275, 22300-22304. [CrossRef] [PubMed]

194. Tzivion, G.; Luo, Z.; Avruch, J. A dimeric 14-3-3 protein is an essential cofactor for Raf kinase activity. Nature 1998, 394, 88-92. [CrossRef] [PubMed]

195. Mischak, H.; Seitz, T.; Janosch, P.; Eulitz, M.; Steen, H.; Schellerer, M.; Philipp, A.; Kolch, W. Negative regulation of Raf-1 by phosphorylation of serine 621. Mol. Cell. Biol. 1996, 16, 5409-5418. [CrossRef] [PubMed]

196. Thorson, J.A.; Yu, L.W.; Hsu, A.L.; Shih, N.Y.; Graves, P.R.; Tanner, J.W.; Allen, P.M.; Piwnica-Worms, H.; Shaw, A.S. 14-3-3 proteins are required for maintenance of Raf-1 phosphorylation and kinase activity. Mol. Cell. Biol. 1998, 18, 5229-5238. [CrossRef] [PubMed]

197. Dougherty, M.K.; Müller, J.; Ritt, D.A.; Zhou, M.; Zhou, X.Z.; Copeland, T.D.; Conrads, T.P.; Veenstra, T.D.; Lu, K.P.; Morrison, D.K. Regulation of Raf-1 by direct feedback phosphorylation. Mol. Cell 2005, 17, $215-224$. [CrossRef] [PubMed]

198. Rushworth, L.K.; Hindley, A.D.; Neill, E.O.; Kolch, W. Regulation and Role of Raf-1 / B-Raf Heterodimerization. Mol. Cell. Biol. 2006, 26, 2262-2272. [CrossRef] [PubMed]

199. Roskoski, R. ERK1/2 MAP kinases: Structure, function, and regulation. Pharmacol. Res. 2012, 66, 105-143. [CrossRef] [PubMed]

200. Fujioka, A.; Terai, K.; Itoh, R.E.; Aoki, K.; Nakamura, T.; Kuroda, S.; Nishida, E.; Matsuda, M. Dynamics of the Ras/ERK MAPK cascade as monitored by fluorescent probes. J. Biol. Chem. 2006, 281, 8917-8926. [CrossRef] [PubMed]

201. Roberts, P.J.; Der, C.J. Targeting the Raf-MEK-ERK mitogen-activated protein kinase cascade for the treatment of cancer. Oncogene 2007, 26, 3291-3310. [CrossRef] [PubMed]

202. Brunet, A.; Pagès, G.; Pouysségur, J. Constitutively active mutants of MAP kinase kinase (MEK1) induce growth factor-relaxation and oncogenicity when expressed in fibroblasts. Oncogene 1994, 9, 3379-3387. [PubMed] 
203. Cowley, S.; Paterson, H.; Kemp, P.; Marshall, C.J. Activation of MAP kinase kinase is necessary and sufficient for PC12 differentiation and for transformation of NIH 3T3 cells. Cell 1994, 77, 841-852. [CrossRef]

204. Lefloch, R.; Pouysségur, J.; Lenormand, P. Total ERK1/2 activity regulates cell proliferation. Cell Cycle 2009, 8, 705-711. [CrossRef] [PubMed]

205. Yoon, S.; Seger, R. The extracellular signal-regulated kinase: Multiple substrates regulate diverse cellular functions. Growth Factors 2006, 24, 21-44. [CrossRef] [PubMed]

206. Richards, S.A.; Dreisbach, V.C.; Murphy, L.O.; Blenis, J. Characterization of regulatory events associated with membrane targeting of p90 ribosomal S6 kinase 1. Mol. Cell. Biol. 2001, 21, 7470-7480. [CrossRef] [PubMed]

207. Dalby, K.N.; Morrice, N.; Caudwell, F.B.; Avruch, J.; Cohen, P. Identification of regulatory phosphorylation sites in mitogen-activated protein kinase (MAPK)-activated protein kinase-1a/p90(rsk) that are inducible by MAPK. J. Biol. Chem. 1998, 273, 1496-1505. [CrossRef] [PubMed]

208. Jensen, C.J.; Buch, M.B.; Krag, T.O.; Hemmings, B.A.; Gammeltoft, S.; Frödin, M. 90-kDa ribosomal S6 kinase is phosphorylated and activated by 3- phosphoinositide-dependent protein kinase-1. J. Biol. Chem. 1999, 274, 27168-27176. [CrossRef] [PubMed]

209. Anjum, R.; Blenis, J. The RSK family of kinases: Emerging roles in cellular signalling. Nat. Rev. Mol. Cell. Biol. 2008, 9, 747-758. [CrossRef] [PubMed]

210. Dhillon, A.S.; Hagan, S.; Rath, O.; Kolch, W. MAP kinase signalling pathways in cancer. Oncogene 2007, 26, 3279-3290. [CrossRef] [PubMed]

211. Murphy, L.O.; Blenis, J. MAPK signal specificity: The right place at the right time. Trends Biochem Sci 2006, 31, 268-275. [CrossRef] [PubMed]

212. Stacey, D.W.; Watson, T.; Kung, H.F.; Curran, T. Microinjection of transforming ras protein induces $c-f o s$ expression. Mol. Cell. Biol. 1987, 7, 523-527. [CrossRef] [PubMed]

213. Quantin, B.; Breathnach, R. Epidermal growth factor stimulates transcription of the c-jun proto-oncogene in rat fibroblasts. Nature 1988, 334, 538-539. [CrossRef] [PubMed]

214. Hollenhorst, P.C.; McIntosh, L.P.; Graves, B.J. Genomic and biochemical insights into the specificity of ETS transcription factors. Annu. Rev. Biochem. 2011, 80, 437-471. [CrossRef] [PubMed]

215. Buchwalter, G.; Gross, C.; Wasylyk, B. Ets ternary complex transcription factors. Gene 2004, 324, 1-14. [CrossRef] [PubMed]

216. Herber, B.; Truss, M.; Beato, M.; Muller, R. Inducible regulatory elements in the human Cyclin D1 promoter. Oncogene 1994, 9, 1295-1304. [PubMed]

217. Albanese, C.; Johnson, J.; Watanabe, G.; Eklund, N.; Vu, D.; Arnold, A.; Pestell, R.G. Transforming p21(ras) mutants and c-Ets-2 activate the Cyclin D1 promoter through distinguishable regions. J. Biol. Chem. 1995, 270, 23589-23597. [CrossRef] [PubMed]

218. Okazaki, K.; Sagata, N. The Mos/MAP kinase pathway stabilizes $c$-fos by phosphorylation and augments its transforming activity in NIH 3 T3 cells. EMBO J. 1995, 14, 5048-5059. [PubMed]

219. Morton, S.; Davis, R.J.; McLaren, A.; Cohen, P. A reinvestigation of the multisite phosphorylation of the transcription factor c-Jun. EMBO J. 2003, 22, 3876-3886. [CrossRef] [PubMed]

220. Jin, Y.; Han, B.; Chen, J.; Wiedemeyer, R.; Orsulic, S.; Bose, S.; Zhang, X.; Karlan, B.Y.; Giuliano, A.E.; Cui, Y.; et al. FOXC1 is a critical mediator of EGFR function in human basal-like breast cancer. Ann. Surg. Oncol. 2014, 21, S758-S766. [CrossRef] [PubMed]

221. Berry, F.B.; Mirzayans, F.; Walter, M.A. Regulation of FOXC1 stability and transcriptional activity by an epidermal growth factor-activated mitogen-activated protein kinase signaling cascade. J. Biol. Chem. 2006, 281, 10098-10104. [CrossRef] [PubMed]

222. Chambard, J.C.; Lefloch, R.; Pouysségur, J.; Lenormand, P. ERK implication in cell cycle regulation. Biochim. Biophys. Acta Mol. Cell Res 2007, 1773, 1299-1310. [CrossRef] [PubMed]

223. Dibble, C.C.; Cantley, L.C. Regulation of mTORC1 by PI3K signaling. Trends Cell Biol. 2015, 25, 545-555. [CrossRef] [PubMed]

224. Whitman, M.; Downes, C.P.; Keeler, M.; Keller, T.; Cantley, L. Type I phosphatidylinositol kinase makes a novel inositol phospholipid, phosphatidylinositol-3-phosphate. Nature 1988, 332, 644-666. [CrossRef] [PubMed]

225. Bjorge, J.D.; Chan, T.O.; Antczak, M.; Kung, H.J.; Fujita, D.J. Activated type I phosphatidylinositol kinase is associated with the epidermal growth factor (EGF) receptor following EGF stimulation. Proc. Natl. Acad. Sci. USA 1990, 87, 3816-3820. [CrossRef] [PubMed] 
226. Thorpe, L.M.; Yuzugullu, H.; Zhao, J.J. PI3K in cancer: Divergent roles of isoforms, modes of activation and therapeutic targeting. Nat. Rev. Cancer 2015, 15, 7-24. [CrossRef] [PubMed]

227. Fruman, D.A.; Cantley, L.C. Phosphoinositide 3-kinase in immunological systems. Semin. Immunol. 2002, 14, 7-18. [CrossRef] [PubMed]

228. Auger, K.R.; Serunian, L.A.; Soltoff, S.P.; Libby, P.; Cantley, L.C. PDGF-dependent tyrosine phosphorylation stimulates production of novel polyphosphoinositides in intact cells. Cell 1989, 57, 167-175. [CrossRef]

229. Carpenter, C.L.; Duckworth, B.C.; Auger, K.R.; Cohen, B.; Schaffhausen, B.S.; Cantley, L.C. Purification and characterization of phosphoinositide 3-kinase from rat liver. J. Biol. Chem. 1990, 265, 19704-19711. [PubMed]

230. Vogt, P.K.; Hart, J.R.; Gymnopoulos, M.; Jiang, H.; Kang, S.; Bader, A.G.; Zhao, L.; Denley, A. Phosphatidylinositol 3-kinase: The oncoprotein. Curr. Top. Microbiol. Immunol. 2010, 347, 79-104. [CrossRef] [PubMed]

231. Salmena, L.; Carracedo, A.; Pandolfi, P.P. Tenets of PTEN tumor suppression. Cell 2008, 133, $403-414$. [CrossRef] [PubMed]

232. Vanhaesebroeck, B.; Stephens, L.; Hawkins, P. PI3K signalling: The path to discovery and understanding. Nat. Rev. Mol. Cell. Biol. 2012, 13, 195-203. [CrossRef] [PubMed]

233. Soltoff, S.P.; Carraway, K.L.; Prigent, S.A.; Gullick, W.G.; Cantley, L.C. ErbB3 is involved in activation of phosphatidylinositol 3-kinase by epidermal growth factor. Mol. Cell. Biol. 1994, 14, 3550-3558. [CrossRef] [PubMed]

234. Kim, H.H.; Sierke, S.L.; Koland, J.G. Epidermal growth factor-dependent association of phosphatidylinositol 3-kinase with the erbB3 gene product. J. Biol. Chem. 1994, 269, 24747-24755. [PubMed]

235. Soltoff, S.P.; Cantley, L.C. p120cbl is a cytosolic adapter protein that associates with phosphoinositide 3-kinase in response to epidermal growth factor in PC12 and other cells. J. Biol. Chem. 1996, 271, 563-567. [CrossRef] [PubMed]

236. Mattoon, D.R.; Lamothe, B.; Lax, I.; Schlessinger, J. The docking protein Gab1 is the primary mediator of EGF-stimulated activation of the PI-3K/Akt cell survival pathway. BMC Biol. 2004, 2, 24. [CrossRef] [PubMed]

237. Lock, L.S.; Royal, I.; Naujokas, M.A.; Park, M. Identification of an atypical Grb2 carboxyl-terminal SH3 domain binding site in Gab docking proteins reveals Grb2-dependent and -independent recruitment of Gab1 to receptor tyorosine kinases. J. Biol. Chem. 2000, 275, 31536-31545. [CrossRef] [PubMed]

238. Liu, Y.; Rohrschneider, L.R. The gift of Gab. FEBS Lett. 2002, 515, 1-7. [CrossRef]

239. Maroun, C.R.; Holgado-Madruga, M.; Royal, I.; Naujokas, M.A.; Fournier, T.M.; Wong, A.J.; Park, M. The Gab1 PH domain is required for localization of Gab1 at sites of cell-cell contact and epithelial morphogenesis downstream from the met receptor tyrosine kinase. Mol. Cell. Biol. 1999, 19, 1784-1799. [CrossRef] [PubMed]

240. Sjölander, A.; Yamamoto, K.; Huber, B.E.; Lapetina, E.G. Association of p21ras with phosphatidylinositol 3-kinase. Proc. Natl. Acad. Sci. USA 1991, 88, 7908-7912. [CrossRef] [PubMed]

241. Rodriguez-Viciana, P.; Warne, P.H.; Vanhaesebroeck, B.; Waterfield11, M.D.; Downward, J. Activation of phosphoinositide 3-kinase by interaction with Ras and by point mutation. EMBO J. 1996, 15, 2442-2451. [PubMed]

242. Cuevas, B.D.; Lu, Y.; Mao, M.; Zhang, J.; LaPushin, R.; Siminovitch, K.; Mills, G.B. Tyrosine Phosphorylation of p85 Relieves Its Inhibitory Activity on Phosphatidylinositol 3-Kinase. J. Biol. Chem. 2001, 276, 27455-27461. [CrossRef] [PubMed]

243. Franke, T.F.; Kaplan, D.R.; Cantley, L.C.; Toker, A. Direct regulation of the Akt proto-oncogene product by phosphatidylinositol-3,4-bisphosphate. Science 1997, 275, 665-668. [CrossRef] [PubMed]

244. Chan, C.H.; Li, C.F.; Yang, W.L.; Gao, Y.; Lee, S.W.; Feng, Z.; Huang, H.Y.; Tsai, K.K.C.; Flores, L.G.; Shao, Y. The Skp2-SCF E3 ligase regulates akt ubiquitination, glycolysis, herceptin sensitivity, and tumorigenesis. Cell 2012, 149, 1098-1111. [CrossRef] [PubMed]

245. Toker, A.; Newton, A.C. Akt/protein kinase B is regulated by autophosphorylation at the hypothetical PDK-2 site. J. Biol. Chem. 2000, 275, 8271-8274. [CrossRef] [PubMed]

246. Pearce, L.R.; Komander, D.; Alessi, D.R. The nuts and bolts of AGC protein kinases. Nat. Rev. Mol. Cell. Biol. 2010, 11, 9-22. [CrossRef] [PubMed] 
247. Stephens, L.; Anderson, K.; Stokoe, D.; Erdjument-Bromage, H.; Painter, G.F.; Holmes, A.B.; Gaffney, P.R.; Reese, C.B.; McCormick, F.; Tempst, P.; et al. Protein kinase B kinases that mediate phosphatidylinositol 3,4,5trisphosphate-dependent activation of protein kinase B. Science 1998, 279, 710-714. [CrossRef] [PubMed]

248. Casamayor, A.; Morrice, N.A.; Alessi, D.R. Phosphorylation of Ser-241 is essential for the activity of 3-phosphoinositide-dependent protein kinase-1: Identification of five sites of phosphorylation in vivo. Biochem. J. 1999, 342, 287-292. [CrossRef] [PubMed]

249. Sarbassov, D.D.; Guertin, D.A.; Ali, S.M.; Sabatini, D.M. Phosphorylation and regulation of Akt/PKB by the rictor-mTOR complex. Science 2005, 307, 1098-1101. [CrossRef] [PubMed]

250. Gao, T.; Furnari, F.; Newton, A.C. PHLPP: A phosphatase that directly dephosphorylates Akt, promotes apoptosis, and suppresses tumor growth. Mol. Cell 2005, 18, 13-24. [CrossRef] [PubMed]

251. Brognard, J.; Sierecki, E.; Gao, T.; Newton, A.C. PHLPP and a Second Isoform, PHLPP2, Differentially Attenuate the Amplitude of Akt Signaling by Regulating Distinct Akt Isoforms. Mol. Cell 2007, 25, 917-931. [CrossRef] [PubMed]

252. Andjelković, M.; Jakubowicz, T.; Cron, P.; Ming, X.F.; Han, J.W.; Hemmings, B.A. Activation and phosphorylation of a pleckstrin homology domain containing protein kinase (RAC-PK/PKB) promoted by serum and protein phosphatase inhibitors. Proc. Natl. Acad. Sci. USA 1996, 93, 5699-5704. [CrossRef] [PubMed]

253. Santi, S.A.; Lee, H. The Akt isoforms are present at distinct subcellular locations. Am. J. Physiol. Cell Physiol. 2010, 298, C580-C591. [CrossRef] [PubMed]

254. Yang, Z.; Tschopp, O. Protein kinase B $\alpha /$ Akt1 regulates placental development and fetal growth. J. Biol. Chem. 2003, 278, 32124-32131. [CrossRef] [PubMed]

255. Zinda, M.J.; Johnson, M.A.; Paul, J.D.; Horn, C.; Konicek, B.W.; Zhao, H.L.; Sandusky, G.; Thomas, J.E.; Neubauer, B.L.; Lai, M.T.; et al. AKT-1, -2, and -3 are expressed in both normal and tumor tissues of the lung, breast, prostate, and colon. Clin. Cancer Res. 2001, 7, 2475-2479. [CrossRef] [PubMed]

256. Cariaga-Martinez, A.E.; López-Ruiz, P.; Nombela-Blanco, M.P.; Motiño, O.; González-Corpas, A.; Rodriguez-Ubreva, J.; Lobo, M.V.T.; Cortés, M.A.; Colás, B. Distinct and specific roles of AKT1 and AKT2 in androgen-sensitive and androgen-independent prostate cancer cells. Cell Signal. 2013, 25, 1586-1597. [CrossRef] [PubMed]

257. Cho, H.; Thorvaldsen, J.L.; Chu, Q.; Feng, F.; Birnbaum, M.J. Akt1/PKBalpha Is Required for Normal Growth but Dispensable for Maintenance of Glucose Homeostasis in Mice. J. Biol. Chem. 2001, 276, 38349-38352. [CrossRef] [PubMed]

258. Dummler, B.; Tschopp, O.; Hynx, D.; Yang, Z.-Z.; Dirnhofer, S.; Hemmings, B.A. Life with a single isoform of Akt: Mice lacking Akt2 and Akt3 are viable but display impaired glucose homeostasis and growth deficiencies. Mol. Cell. Biol. 2006, 26, 8042-8051. [CrossRef] [PubMed]

259. Garofalo, R.S.; Orena, S.J.; Rafidi, K.; Torchia, A.J.; Stock, J.L.; Hildebrandt, A.L.; Coskran, T.; Black, S.C.; Brees, D.J.; Wicks, J.R.; et al. Severe diabetes, age-dependent loss of adipose tissue, and mild growth deficiency in mice lacking Akt2/PKB?? J. Clin. Investig. 2003, 112, 197-208. [CrossRef] [PubMed]

260. Arboleda, M.J.; Lyons, J.F.; Kabbinavar, F.F.; Bray, M.R.; Snow, B.E.; Ayala, R.; Danino, M.; Karlan, B.Y.; Slamon, D.J. Overexpression of AKT2/protein kinase B beta leads to up- regulation of beta 1 integrins, increased invasion, and metastasis of human breast and ovarian cancer cells. Cancer Res. 2003, 63, 196-206. [PubMed]

261. Irie, H.; Pearline, R.; Grueneberg, D. Distinct roles of Akt1 and Akt2 in regulating cell migration and epithelial-mesenchymal transition. J. Cell Boil. 2005, 17, 1023-1034. [CrossRef] [PubMed]

262. Ju, X.; Katiyar, S.; Wang, C.; Liu, M.; Jiao, X.; Li, S.; Zhou, J.; Turner, J.; Lisanti, M.P.; Russell, R.G.; et al. Akt1 governs breast cancer progression in vivo. Proc. Natl. Acad. Sci. USA 2007, 104, 7438-7443. [CrossRef] [PubMed]

263. Lee, M.W.; Kim, D.S.; Lee, J.H.; Lee, B.S.; Lee, S.H.; Jung, H.L.; Sung, K.W.; Kim, H.T.; Yoo, K.H.; Koo, H.H. Roles of AKT1 and AKT2 in non-small cell lung cancer cell survival, growth, and migration. Cancer Sci. 2011, 102, 1822-1828. [CrossRef] [PubMed]

264. Héron-Milhavet, L.; Franckhauser, C.; Rana, V.; Berthenet, C.; Fisher, D.; Hemmings, B.A.; Fernandez, A.; Lamb, N.J.C. Only Akt1 is required for proliferation, while Akt2 promotes cell cycle exit through p21 binding. Mol. Cell. Biol. 2006, 26, 8267-8280. [CrossRef] [PubMed] 
265. Linnerth-Petrik, N.M.; Santry, L.A.; Petrik, J.J.; Wootton, S.K. Opposing functions of Akt isoforms in lung tumor initiation and progression. PLoS ONE 2014, 9, e94595. [CrossRef] [PubMed]

266. Stål, O.; Pérez-Tenorio, G.; Akerberg, L.; Olsson, B.; Nordenskjöld, B.; Skoog, L.; Rutqvist, L.E. Akt kinases in breast cancer and the results of adjuvant therapy. Breast Cancer Res. 2003, 5, R37-R44. [CrossRef] [PubMed]

267. Staal, S.P. Molecular cloning of the akt oncogene and its human homologues AKT1 and AKT2: Amplification of AKT1 in a primary human gastric adenocarcinoma. Proc. Natl. Acad. Sci. USA 1987, 84, 5034-5037. [CrossRef] [PubMed]

268. Carpten, J.D.; Faber, A.L.; Horn, C.; Donoho, G.P.; Briggs, S.L.; Robbins, C.M.; Hostetter, G.; Boguslawski, S.; Moses, T.Y.; Savage, S.; et al. A transforming mutation in the pleckstrin homology domain of AKT1 in cancer. Nature 2007, 448, 439-444. [CrossRef] [PubMed]

269. Chen, M.L.; Xu, P.Z.; Peng, X.D.; Chen, W.S.; Guzman, G.; Yang, X.; Di Cristofano, A.; Pandolfi, P.P.; Hay, N. The deficiency of Akt1 is sufficient to suppress tumor development in Pten+/- mice. Genes Dev. 2006, 20, 1569-1574. [CrossRef] [PubMed]

270. Cheng, J.Q.; Ruggeri, B.; Klein, W.M.; Sonoda, G.; Altomare, D.A.; Watson, D.K.; Testa, J.R. Amplification of AKT2 in human pancreatic cells and inhibition of AKT2 expression and tumorigenicity by antisense RNA. Proc. Natl. Acad. Sci. USA 1996, 93, 3636-3641. [CrossRef] [PubMed]

271. Cheng, J.Q.; Godwin, A.K.; Bellacosa, A.; Taguchi, T.; Franke, T.F.; Hamilton, T.C.; Tsichlis, P.N.; Testa, J.R. AKT2, a putative oncogene encoding a member of a subfamily of protein-serine/threonine kinases, is amplified in human ovarian carcinomas. Proc. Natl. Acad. Sci. USA 1992, 89, 9267-9271. [CrossRef] [PubMed]

272. Roy, H.K.; Olusola, B.F.; Clemens, D.L.; Karolski, W.J.; Ratashak, A.; Lynch, H.T.; Smyrk, T.C. AKT proto-oncogene overexpression is an early event during sporadic colon carcinogenesis. Carcinogenesis 2002, 23, 201-205. [CrossRef] [PubMed]

273. Xu, X.; Sakon, M.; Nagano, H.; Hiraoka, N.; Yamamoto, H.; Hayashi, N.; Dono, K.; Nakamori, S.; Umeshita, K.; Ito, Y.; et al. Akt2 expression correlates with prognosis of human hepatocellular carcinoma. Oncol. Rep. 2004, 11, 25-32. [CrossRef] [PubMed]

274. Altomare, D.A.; Testa, J.R. Perturbations of the AKT signaling pathway in human cancer. Oncogene 2005, 24, 7455-7464. [CrossRef] [PubMed]

275. Parsons, D.W.; Wang, T.-L.; Samuels, Y.; Bardelli, A.; Cummins, J.M.; DeLong, L.; Silliman, N.; Ptak, J.; Szabo, S.; Willson, J.K.V.; et al. Colorectal cancer: Mutations in a signalling pathway. Nature 2005, 436, 792. [CrossRef] [PubMed]

276. Okano, J.; Gaslightwala, I.; Birnbaum, M.J.; Rustgi, A.K.; Nakagawa, H. Akt/protein kinase B isoforms are differentially regulated by epidermal growth factor stimulation. J. Biol. Chem. 2000, 275, 30934-30942. [CrossRef] [PubMed]

277. Zhou, B.P.; Hu, M.C.; Miller, S.A.; Yu, Z.; Xia, W.; Lin, S.Y.; Hung, M.C. HER-2/neu blocks tumor necrosis factor-induced apoptosis via the Akt/NF-kappaB pathway. J. Biol. Chem. 2000, 275, 8027-8031. [CrossRef] [PubMed]

278. Datta, S.R.; Dudek, H.; Xu, T.; Masters, S.; Haian, F.; Gotoh, Y.; Greenberg, M.E. Akt phosphorylation of BAD couples survival signals to the cell- intrinsic death machinery. Cell 1997, 91, 231-241. [CrossRef]

279. Cardone, M.H. Regulation of Cell Death Protease Caspase-9 by Phosphorylation. Science 1998, 282, $1318-1321$. [CrossRef] [PubMed]

280. Tang, E.D.; Nuñez, G.; Barr, F.G.; Guan, K.L. Negative regulation of the forkhead transcription factor FKHR by Akt. J. Biol. Chem. 1999, 274, 16741-16746. [CrossRef] [PubMed]

281. Brunet, A.; Bonni, A.; Zigmond, M.J.; Lin, M.Z.; Juo, P.; Hu, L.S.; Anderson, M.J.; Arden, K.C.; Blenis, J.; Greenberg, M.E. Akt promotes cell survival by phosphorylating and inhibiting a Forkhead transcription factor. Cell 1999, 96, 857-868. [CrossRef]

282. Ogawara, Y.; Kishishita, S.; Obata, T.; Isazawa, Y.; Suzuki, T.; Tanaka, K.; Masuyama, N.; Gotoh, Y. Akt enhances Mdm2-mediated ubiquitination and degradation of p53. J. Biol. Chem. 2002, 277, 21843-21850. [CrossRef] [PubMed]

283. Zhou, B.P.; Liao, Y.; Xia, W.; Zou, Y.; Spohn, B.; Hung, M.C. HER-2/neu induces p53 ubiquitination via Akt-mediated MDM2 phosphorylation. Nat. Cell Biol. 2001, 3, 973-982. [CrossRef] [PubMed] 
284. Feng, J.; Tamaskovic, R.; Yang, Z.; Brazil, D.P.; Merlo, A.; Hess, D.; Hemmings, B.A. Stabilization of Mdm2 via decreased ubiquitination is mediated by protein kinase B/Akt-dependent phosphorylation. J. Biol. Chem. 2004, 279, 35510-35517. [CrossRef] [PubMed]

285. Peterson, T.R.; Laplante, M.; Thoreen, C.C.; Sancak, Y.; Kang, S.A.; Kuehl, W.M.; Gray, N.S.; Sabatini, D.M. DEPTOR Is an mTOR Inhibitor Frequently Overexpressed in Multiple Myeloma Cells and Required for Their Survival. Cell 2009, 137, 873-886. [CrossRef] [PubMed]

286. Shaw, R.J.; Cantley, L.C. Ras, PI(3)K and mTOR signalling controls tumour cell growth. Nature 2006, 441, 424-430. [CrossRef] [PubMed]

287. Huang, J.; Manning, B.D. The TSC1-TSC2 complex: A molecular switchboard controlling cell growth. Biochem. J. 2008, 412, 179-190. [CrossRef] [PubMed]

288. Inoki, K.; Li, Y.; Zhu, T.; Wu, J.; Guan, K.-L. TSC2 is phosphorylated and inhibited by Akt and suppresses mTOR signalling. Nat. Cell Biol. 2002, 4, 648-657. [CrossRef] [PubMed]

289. Manning, B.D.; Tee, A.R.; Logsdon, M.N.; Blenis, J.; Cantley, L.C. Identification of the tuberous sclerosis complex-2 tumor suppressor gene product tuberin as a target of the phosphoinositide 3-kinase/Akt pathway. Mol. Cell 2002, 10, 151-162. [CrossRef]

290. Ma, L.; Chen, Z.; Erdjument-Bromage, H.; Tempst, P.; Pandolfi, P.P. Phosphorylation and functional inactivation of TSC2 by Erk: Implications for tuberous sclerosis and cancer pathogenesis. Cell 2005, 121, 179-193. [CrossRef] [PubMed]

291. Tee, A.R.; Fingar, D.C.; Manning, B.D.; Kwiatkowski, D.J.; Cantley, L.C.; Blenis, J. Tuberous sclerosis complex-1 and -2 gene products function together to inhibit mammalian target of rapamycin (mTOR)-mediated downstream signaling. Proc. Natl. Acad. Sci. USA 2002, 99, 13571-13576. [CrossRef] [PubMed]

292. Scott, P.H.; Brunn, G.J.; Kohn, A.D.; Roth, R.A.; Lawrence, J.C., Jr. Evidence of insulin-stimulated phosphorylation and activation of the mammalian target of rapamycin mediated by a protein kinase B signaling pathway. Proc. Natl. Acad. Sci. USA 1998, 95, 7772-7777. [CrossRef] [PubMed]

293. Dan, H.C.; Ebbs, A.; Pasparakis, M.; Van Dyke, T.; Basseres, D.S.; Baldwin, A.S. Akt-dependent activation of mTORC1 complex involves phosphorylation of mTOR (mammalian target of rapamycin) by IкB kinase $\alpha$ (IKK $\alpha$ ). J. Biol. Chem. 2014, 289, 25227-25240. [CrossRef] [PubMed]

294. Acosta-Jaquez, H.A.; Keller, J.A.; Foster, K.G.; Ekim, B.; Soliman, G.A.; Feener, E.P.; Ballif, B.A.; Fingar, D.C. Site-specific mTOR phosphorylation promotes mTORC1-mediated signaling and cell growth. Mol. Cell. Biol. 2009, 29, 4308-4324. [CrossRef] [PubMed]

295. Abraham, R.T. mTOR as a positive regulator of tumor cell responses to hypoxia. Curr. Top. Microbiol. Immunol. 2004, 279, 299-319. [PubMed]

296. Grewe, M.; Gansauge, F.; Schmid, R.M.; Adler, G.; Seufferlein, T. Regulation of cell growth and Cyclin D1 expression by the constitutively active FRAP-p70(s6K) pathway in human pancreatic cancer cells. Cancer Res. 1999, 59, 3581-3587. [PubMed]

297. Averous, J.; Fonseca, B.D.; Proud, C.G. Regulation of cyclin D1 expression by mTORC1 signaling requires eukaryotic initiation factor 4E-binding protein 1. Oncogene 2008, 27, 1106-1113. [CrossRef] [PubMed]

298. Vander Heiden, M.G.; Cantley, L.C.; Thompson, C.B. Understanding the Warburg effect: The metabolic requirements of cell proliferation. Science 2009, 324, 1029-1033. [CrossRef] [PubMed]

299. Elstrom, R.L.; Bauer, D.E.; Buzzai, M.; Karnauskas, R.; Harris, M.H.; Plas, D.R.; Zhuang, H.; Cinalli, R.M.; Alavi, A.; Rudin, C.M.; et al. Akt stimulates aerobic glycolysis in cancer cells. Cancer Res. 2004, 64, 3892-3899. [CrossRef] [PubMed]

300. Courtnay, R.; Ngo, D.C.; Malik, N.; Ververis, K.; Tortorella, S.M.; Karagiannis, T.C. Cancer metabolism and the Warburg effect: The role of HIF-1 and PI3K. Mol. Biol. Rep. 2015, 42, 841-851. [CrossRef] [PubMed]

301. Lien, E.C.; Lyssiotis, C.A.; Cantley, L.C. Metabolic Reprogramming by the PI3K-Akt-mTOR Pathway in Cancer. Recent Res. Cancer Res. 2016, 207, 39-72. [CrossRef]

302. Nakamura, Y.; Fukami, K. Roles of phospholipase $C$ isozymes in organogenesis and embryonic development. Physiology 2009, 24, 332-341. [CrossRef] [PubMed]

303. Ji, Q.S.; Winnier, G.E.; Niswender, K.D.; Horstman, D.; Wisdom, R.; Magnuson, M.A.; Carpenter, G. Essential role of the tyrosine kinase substrate phospholipase C- $\gamma 1$ in mammalian growth and development. Proc. Natl. Acad. Sci. USA 1997, 94, 2999-3003. [CrossRef] [PubMed] 
304. Liao, H.J.; Kume, T.; McKay, C.; Xu, M.J.; Ihle, J.N.; Carpenter, G. Absence of erythrogenesis and vasculogenesis in Plcg1-deficient mice. J. Biol. Chem. 2002, 277, 9335-9341. [CrossRef] [PubMed]

305. Sala, G.; Dituri, F.; Raimondi, C.; Previdi, S.; Maffucci, T.; Mazzoletti, M.; Rossi, C.; Iezzi, M.; Lattanzio, R.; Piantelli, M.; et al. Phospholipase Cgamma1 is required for metastasis development and progression. Cancer Res. 2008, 68, 10187-10196. [CrossRef] [PubMed]

306. Lattanzio, R.; Piantelli, M.; Falasca, M. Role of phospholipase C in cell invasion and metastasis. Adv. Biol. Regul. 2013, 53, 309-318. [CrossRef] [PubMed]

307. Rotin, D.; Margolis, B.; Mohammadi, M.; Daly, R.J.; Daum, G.; Li, N.; Fischer, E.H.; Burgess, W.H.; Ullrich, A.; Schlessinger, J. SH2 domains prevent tyrosine dephosphorylation of the EGF receptor: Identification of Tyr992 as the high-affinity binding site for SH2 domains of phospholipase C gamma. EMBO J. 1992, 11, 559-567. [PubMed]

308. Anderson, D.; Koch, C.A.; Grey, L.; Ellis, C.; Moran, M.F.; Pawson, T. Binding of SH2 domains of phospholipase C gamma 1, GAP, and Src to activated growth factor receptors. Science 1990, 250, 979-982. [CrossRef] [PubMed]

309. Chattopadhyay, A.; Vecchi, M.; Ji, Q.S.; Mernaugh, R.; Carpenter, G. The role of individual SH2 domains in mediating association of phospholipase C- $\gamma 1$ with the activated EGF receptor. J. Biol. Chem. 1999, 274, 26091-26097. [CrossRef] [PubMed]

310. Falasca, M.; Logan, S.K.; Lehto, V.P.; Baccante, G.; Lemmon, M.A.; Schlessinger, J. Activation of phospholipase C gamma by PI 3-kinase-induced PH domain- mediated membrane targeting. EMBO J. 1998, 17, 414-422. [CrossRef] [PubMed]

311. Nishibe, S.; Wahl, M.I.; Hernández-Sotomayor, S.M.; Tonks, N.K.; Rhee, S.G.; Carpenter, G. Increase of the catalytic activity of phospholipase C-gamma 1 by tyrosine phosphorylation. Science 1990, 250, 1253-1256. [CrossRef] [PubMed]

312. Serrano, C.J.; Graham, L.; DeBell, K.; Rawat, R.; Veri, M.C.; Bonvini, E.; Rellahan, B.L.; Reischl, I.G. A New Tyrosine Phosphorylation Site in PLC $\gamma 1$ : The Role of Tyrosine 775 in Immune Receptor Signaling. J. Immunol. 2005, 174, 6233-6237. [CrossRef] [PubMed]

313. Gresset, A.; Hicks, S.N.; Harden, T.K.; Sondek, J. Mechanism of phosphorylation-induced activation of phospholipase C-gamma isozymes. J. Biol. Chem. 2010, 285, 35836-35847. [CrossRef] [PubMed]

314. Kang, J.H.; Toita, R.; Kim, C.W.; Katayama, Y. Protein kinase C (PKC) isozyme-specific substrates and their design. Biotechnol. Adv. 2012, 30, 1662-1672. [CrossRef] [PubMed]

315. Cazaubon, S.; Bornancin, F.; Parker, P.J. Threonine-497 is a critical site for permissive activation of protein kinase C alpha. Biochem. J. 1994, 301 (Pt 2), 443-448. [CrossRef] [PubMed]

316. Cazaubon, S.M.; Parker, P.J. Identification of the phosphorylated region responsible for the permissive activation of protein kinase C. J. Biol. Chem. 1993, 268, 17559-17563. [PubMed]

317. Lund, K.A.; Lazar, C.S.; Chen, W.S.; Walsh, B.J.; Welsh, J.B.; Herbst, J.J.; Walton, G.M.; Rosenfeld, M.G.; Gill, G.N.; Wiley, H.S. Phosphorylation of the epidermal growth factor receptor at threonine 654 inhibits ligand-induced internalization and down-regulation. J. Biol. Chem. 1990, 265, 20517-20523. [PubMed]

318. Lee, C.S.; Kim, K.L.; Jang, J.H.; Choi, Y.S.; Suh, P.-G.; Ryu, S.H. The roles of phospholipase D in EGFR signaling. Biochim. Biophys. Acta 2009, 1791, 862-868. [CrossRef] [PubMed]

319. Kim, Y.; Han, J.M.; Park, J.B.; Lee, S.D.; Oh, Y.S.; Chung, C.; Lee, T.G.; Kim, J.H.; Park, S.K.; Yoo, J.S.; et al. Phosphorylation and activation of phospholipase D1 by protein kinase $\mathrm{C}$ in vivo: Determination of multiple phosphorylation sites. Biochemistry 1999, 38, 10344-10351. [CrossRef] [PubMed]

320. Song, J.; Jiang, Y.; Foster, D. Epidermal growth factor induces the production of biologically distinguishable diglyceride species from phosphatidylinositol and phosphatidylcholine via the independent activation of type C and type D phospholipases. Cell Growth Differ. 1994, 5, 79-85. [PubMed]

321. Lu, Z.; Hornia, A.; Joseph, T.; Sukezane, T.; Frankel, P.; Zhong, M.; Bychenok, S.; Xu, L.; Feig, L.A.; Foster, D.A. Phospholipase D and RalA cooperate with the epidermal growth factor receptor to transform 3 Y1 rat fibroblasts. Mol. Cell. Biol. 2000, 20, 462-467. [CrossRef] [PubMed]

322. Joseph, T.; Wooden, R.; Bryant, A.; Zhong, M.; Lu, Z.; Foster, D.A. Transformation of cells overexpressing a tyrosine kinase by phospholipase D1 and D2. Biochem. Biophys. Res. Commun. 2001, 289, 1019-1024. [CrossRef] [PubMed]

323. Park, J.B.; Lee, C.S.; Jang, J.-H.; Ghim, J.; Kim, Y.-J.; You, S.; Hwang, D.; Suh, P.-G.; Ryu, S.H. Phospholipase signalling networks in cancer. Nat. Rev. Cancer 2012, 12, 782-792. [CrossRef] [PubMed] 
324. Rous, P. A Sarcoma of the Fowl Transmissible By an Agent Separable From the Tumor Cells. J. Exp. Med. 1911, 13, 397-411. [CrossRef] [PubMed]

325. Xu, W.; Harrison, S.C.; Eck, M.J. Three-dimensional structure of the tyrosine kinase c-Src. Nature 1997, 385, 595-602. [CrossRef] [PubMed]

326. Williams, J.C.; Weijland, A.; Gonfloni, S.; Thompson, A.; Courtneidge, S.A.; Superti-Furga, G.; Wierenga, R.K. The 2.35 A crystal structure of the inactivated form of chicken Src: A dynamic molecule with multiple regulatory interactions. J. Mol. Biol. 1997, 274, 757-775. [CrossRef] [PubMed]

327. Cooper, J.A.; Gould, K.L.; Cartwright, C.A.; Hunter, T. Tyr527 is phosphorylated in pp60c-src: Implications for regulation. Science 1986, 231, 1431-1434. [CrossRef] [PubMed]

328. Okada, M.; Nada, S.; Yamanashi, Y.; Yamamoto, T.; Nakagawa, H. CSK: A protein-tyrosine kinase involved in regulation of src family kinases. J. Biol. Chem. 1991, 266, 24249-24252. [PubMed]

329. Okada, M. Regulation of the Src family kinases by Csk. Int. J. Biol. Sci. 2012, 8, 1385-1397. [CrossRef] [PubMed]

330. Somani, A.K.; Bignon, J.S.; Mills, G.B.; Siminovitch, K.A.; Branch, D.R. Src kinase activity is regulated by the SHP-1 protein-tyrosine phosphatase. J. Biol. Chem. 1997, 272, 21113-21119. [CrossRef] [PubMed]

331. Peng, Z.Y.; Cartwright, C.A. Regulation of the Src tyrosine kinase and Syp tyrosine phosphatase by their cellular association. Oncogene 1995, 11, 1955-1962. [PubMed]

332. Fang, K.S.; Sabe, H.; Saito, H.; Hanafusa, H. Comparative study of three protein-tyrosine phosphatases. Chicken protein-tyrosine phosphatase lambda dephosphorylates c- Src tyrosine 527. J. Biol. Chem. 1994, 269, 20194-20200. [PubMed]

333. Charbonneau, H.; Tonks, N.K.; Kumar, S.; Diltz, C.D.; Harrylock, M.; Cool, D.E.; Krebs, E.G.; Fischer, E.H.; Walsh, K.A. Human placenta protein-tyrosine-phosphatase: Amino acid sequence and relationship to a family of receptor-like proteins. Proc. Natl. Acad. Sci. USA 1989, 86, 5252-5256. [CrossRef] [PubMed]

334. Biscardi, J.S.; Maa, M.-C.; Tice, D.A.; Leu, T.-H.; Parsons, S.J. c-Src-mediated Phosphorylation of the Epidermal Growth Factor Receptor on Tyr845 and Tyr1101 Is Associated with Modulation of Receptor Function. J. Biol. Chem. 1999, 274, 8335-8343. [CrossRef] [PubMed]

335. Hunter, T.; Sefton, B.M. Transforming gene product of Rous sarcoma virus phosphorylates tyrosine. Proc. Natl. Acad. Sci. USA 1980, 77, 1311-1315. [CrossRef] [PubMed]

336. Collett, M.S.; Purchio, A.F.; Erikson, R.L. Avian sarcoma virus-transforming protein, pp60_src_shows protein kinase activity specific for tyrosine. Nature 1980, 285, 167-169. [CrossRef] [PubMed]

337. Levinson, A.D.; Oppermann, H.; Varmus, H.E.; Bishop, J.M. The purified product of the transforming gene of avian sarcoma virus phosphorylates tyrosine. J. Biol. Chem. 1980, 255, 11973-11980. [PubMed]

338. Sen, B.; Johnson, F.M. Regulation of Src Family Kinases in Human Cancers. J. Signal Transduct. 2011, 2011, 1-14. [CrossRef] [PubMed]

339. Thomas, S.M.; Brugge, J.S. Cellular functions regulated by Src family kinases. Annu. Rev. Cell Dev. Biol. 1997, 13, 513-609. [CrossRef] [PubMed]

340. Bao, J.; Gur, G.; Yarden, Y. Src promotes destruction of c-Cbl: Implications for oncogenic synergy between Src and growth factor receptors. Proc. Natl. Acad. Sci. USA 2003, 100, 2438-2443. [CrossRef] [PubMed]

341. Tice, D.A.; Biscardi, J.S.; Nickles, A.l.; Parsons, S.J. Mechanism of biological synergy between cellular Src and epidermal growth factor receptor. Proc. Natl. Acad. Sci. USA 1999, 96, 1415-1420. [CrossRef] [PubMed]

342. Goi, T.; Shipitsin, M.; Lu, Z.; Foster, D.A.; Klinz, S.G.; Feig, L.A. An EGF receptor/Ral-GTPase signaling cascade regulates c-Src activity and substrate specificity. EMBO J. 2000, 19, 623-630. [CrossRef] [PubMed]

343. Maa, M.C.; Leu, T.H.; McCarley, D.J.; Schatzman, R.C.; Parsons, S.J. Potentiation of epidermal growth factor receptor-mediated oncogenesis by c-Src: Implications for the etiology of multiple human cancers. Proc. Natl. Acad. Sci. USA 1995, 92, 6981-6985. [CrossRef] [PubMed]

344. Poole, E.M.; Curtin, K.; Hsu, L.; Kulmacz, R.J.; Duggan, D.J.; Makar, K.W.; Xiao, L.; Carlson, C.S.; Slattery, M.L.; Caan, B.J.; et al. Genetic variability in EGFR, Src and HER2 and risk of colorectal adenoma and cancer. Int. J. Mol. Epidemiol. Genet. 2011, 2, 300-315. [PubMed]

345. Olayioye, M.A.; Beuvink, I.; Horsch, K.; Daly, J.M.; Hynes, N.E. ErbB receptor-induced activation of Stat transcription factors is mediated by Src tyrosine kinases. J. Biol. Chem. 1999, 274, 17209-17218. [CrossRef] [PubMed]

346. Sato, K.; Sato, A.; Aoto, M.; Fukami, Y. c-Src phosphorylates epidermal growth factor receptor on tyrosine 845. Biochem. Biophys. Res. Commun. 1995, 215, 1078-1087. [CrossRef] [PubMed] 
347. Shan, Y.; Eastwood, M.P.; Zhang, X.; Kim, E.T.; Arkhipov, A.; Dror, R.O.; Jumper, J.; Kuriyan, J.; Shaw, D.E. Oncogenic mutations counteract intrinsic disorder in the EGFR kinase and promote receptor dimerization. Cell 2012, 149, 860-870. [CrossRef] [PubMed]

348. Endoh, H.; Ishibashi, Y.; Yamaki, E.; Yoshida, T.; Yajima, T.; Kimura, H.; Kosaka, T.; Onozato, R.; Tanaka, S.; Mitsudomi, T.; et al. Immunohistochemical analysis of phosphorylated epidermal growth factor receptor might provide a surrogate marker of EGFR mutation. Lung Cancer 2009, 63, 241-246. [CrossRef] [PubMed]

349. Chung, B.M.; Dimri, M.; George, M.; Reddi, A.L.; Chen, G.; Band, V.; Band, H. The role of cooperativity with Src in oncogenic transformation mediated by non-small cell lung cancer-associated EGF receptor mutants. Oncogene 2009, 28, 1821-1832. [CrossRef] [PubMed]

350. Mattila, E.; Pellinen, T.; Nevo, J.; Vuoriluoto, K.; Arjonen, A.; Ivaska, J. Negative regulation of EGFR signalling through integrin-alpha1beta1-mediated activation of protein tyrosine phosphatase TCPTP. Nat. Cell Biol. 2005, 7, 78-85. [CrossRef] [PubMed]

351. Baumdick, M.; Brüggemann, Y.; Schmick, M.; Xouri, G.; Sabet, O.; Davis, L.; Chin, J.W.; Bastiaens, P.I.H. EGF-dependent re-routing of vesicular recycling switches spontaneous phosphorylation suppression to EGFR signaling. Elife 2015, 4. [CrossRef] [PubMed]

352. Koppikar, P.; Choi, S.-H.; Egloff, A.M.; Cai, Q.; Suzuki, S.; Freilino, M.; Nozawa, H.; Thomas, S.M.; Gooding, W.E.; Siegfried, J.M.; et al. Combined inhibition of c-Src and epidermal growth factor receptor abrogates growth and invasion of head and neck squamous cell carcinoma. Clin. Cancer Res. 2008, 14, 4284-4291. [CrossRef] [PubMed]

353. Gargalionis, A.N.; Karamouzis, M.V.; Papavassiliou, A.G. The molecular rationale of Src inhibition in colorectal carcinomas. Int. J. Cancer 2014, 134, 2019-2029. [CrossRef] [PubMed]

354. Lin, S.Y.; Makino, K.; Xia, W.; Matin, a.; Wen, Y.; Kwong, K.Y.; Bourguignon, L.; Hung, M.C. Nuclear localization of EGF receptor and its potential new role as a transcription factor. Nat. Cell Biol. 2001, 3, 802-808. [CrossRef] [PubMed]

355. Cao, H.; Lei, Z.M.; Bian, L.; Rao, C.V. Functional nuclear epidermal growth factor receptors in human choriocarcinoma JEG-3 cells and normal human placenta. Endocrinology 1995, 136, 3163-3172. [CrossRef] [PubMed]

356. Lo, H.-W.; Hung, M.-C. Nuclear EGFR signalling network in cancers: Linking EGFR pathway to cell cycle progression, nitric oxide pathway and patient survival. Br. J. Cancer 2006, 94, 184-188. [CrossRef] [PubMed]

357. Wang, Y.-N.; Yamaguchi, H.; Hsu, J.-M.; Hung, M.-C. Nuclear trafficking of the epidermal growth factor receptor family membrane proteins. Oncogene 2010, 29, 3997-4006. [CrossRef] [PubMed]

358. Lo, H.W.; Hsu, S.C.; Ali-Seyed, M.; Gunduz, M.; Xia, W.; Wei, Y.; Bartholomeusz, G.; Shih, J.Y.; Hung, M.C. Nuclear interaction of EGFR and STAT3 in the activation of the iNOS/NO pathway. Cancer Cell 2005, 7, 575-589. [CrossRef] [PubMed]

359. Lee, H.-J.; Lan, L.; Peng, G.; Chang, W.-C.; Hsu, M.-C.; Wang, Y.-N.; Cheng, C.-C.; Wei, L.; Nakajima, S.; Chang, S.-S.; et al. Tyrosine 370 phosphorylation of ATM positively regulates DNA damage response. Cell Res. 2015, 25, 225-236. [CrossRef] [PubMed]

360. Kamio, T.; Shigematsu, K.; Sou, H.; Kawai, K.; Tsuchiyama, H. Immunohistochemical expression of epidermal growth factor receptors in human adrenocortical carcinoma. Hum. Pathol. 1990, 21, 277-282. [CrossRef]

361. Lo, H.W.; Xia, W.; Wei, Y.; Ali-Seyed, M.; Huang, S.F.; Hung, M.C. Novel prognostic value of nuclear epidermal growth factor receptor in breast cancer. Cancer Res. 2005, 65, 338-348. [PubMed]

362. Marti, U.; Ruchti, C.; Kämpf, J.; Thomas, G.A.; Williams, E.D.; Peter, H.J.; Gerber, H.; Bürgi, U. Nuclear localization of epidermal growth factor and epidermal growth factor receptors in human thyroid tissues. Thyroid 2001, 11, 137-145. [CrossRef] [PubMed]

363. Psyrri, A.; Yu, Z.; Weinberger, P.M.; Sasaki, C.; Haffty, B.; Camp, R.; Rimm, D.; Burtness, B.A. Quantitative determination of nuclear and cytoplasmic epidermal growth factor receptor expression in oropharyngeal squamous cell cancer by using automated quantitative analysis. Clin. Cancer Res. 2005, 11, 5856-5862. [CrossRef] [PubMed]

364. Dittmann, K.; Mayer, C.; Fehrenbacher, B.; Schaller, M.; Kehlbach, R.; Rodemann, H.P. Nuclear EGFR shuttling induced by ionizing radiation is regulated by phosphorylation at residue Thr654. FEBS Lett. 2010, 584, 3878-3884. [CrossRef] [PubMed]

365. Liccardi, G.; Hartley, J.A.; Hochhauser, D. EGFR nuclear translocation modulates DNA repair following cisplatin and ionizing radiation treatment. Cancer Res. 2011, 71, 1103-1114. [CrossRef] [PubMed] 
366. Hsu, S.C.; Miller, S.A.; Wang, Y.; Hung, M.C. Nuclear EGFR is required for cisplatin resistance and DNA repair. Am. J. Transl. Res. 2009, 1, 249-258. [PubMed]

367. De Angelis Campos, A.C.; Rodrigues, M.A.; de Andrade, C.; de Goes, A.M.; Nathanson, M.H.; Gomes, D.A. Epidermal growth factor receptors destined for the nucleus are internalized via a clathrin-dependent pathway. Biochem. Biophys. Res. Commun. 2011, 412, 341-346. [CrossRef] [PubMed]

368. Lo, H.W.; Ali-Seyed, M.; Wu, Y.; Bartholomeusz, G.; Hsu, S.C.; Hung, M.C. Nuclear-cytoplasmic transport of EGFR involves receptor endocytosis, importin beta1 and CRM1. J. Cell. Biochem. 2006, 98, 1570-1583. [CrossRef] [PubMed]

369. Wang, Y.N.; Wang, H.; Yamaguchi, H.; Lee, H.J.; Lee, H.H.; Hung, M.C. COPI-mediated retrograde trafficking from the Golgi to the ER regulates EGFR nuclear transport. Biochem. Biophys. Res. Commun. 2010, 399, 498-504. [CrossRef] [PubMed]

370. Jaganathan, S.; Yue, P.; Paladino, D.C.; Bogdanovic, J.; Huo, Q.; Turkson, J. A functional nuclear epidermal growth factor receptor, Src and Stat3 heteromeric complex in pancreatic cancer cells. PLoS ONE 2011, 6, e19605. [CrossRef] [PubMed]

371. Huo, L.; Wang, Y.-N.; Xia, W.; Hsu, S.-C.; Lai, C.-C.; Li, L.-Y.; Chang, W.-C.; Wang, Y.; Hsu, M.-C.; Yu, Y.-L. RNA helicase $\mathrm{A}$ is a DNA-binding partner for EGFR-mediated transcriptional activation in the nucleus. Proc. Natl. Acad. Sci. USA 2010, 107, 16125-16130. [CrossRef] [PubMed]

372. Bitler, B.; Goverdhan, A.; Schroeder, J. MUC1 regulates nuclear localization and function of the EGFR. J. Cell Sci. 2010, 123, 1716-1723. [CrossRef] [PubMed]

373. Martinelli, E.; De Palma, R.; Orditura, M.; De Vita, F.; Ciardiello, F. Anti-epidermal growth factor receptor monoclonal antibodies in cancer therapy. Clin. Exp. Immunol. 2009, 158, 1-9. [CrossRef] [PubMed]

374. Ciardiello, F.; Tortora, G.; Magrassi, S.F.; Lanzara, A. EGFR Antagonists in Cancer Treatment. N. Engl. J. Med. 2008, 358, 1160-1174. [CrossRef] [PubMed]

375. Modjtahedi, H.; Essapen, S. Epidermal growth factor receptor inhibitors in cancer treatment: Advances, challenges and opportunities. Anticancer Drugs 2009, 20, 851-855. [CrossRef] [PubMed]

376. Shukuya, T.; Takahashi, T.; Kaira, R.; Ono, A.; Nakamura, Y.; Tsuya, A.; Kenmotsu, H.; Naito, T.; Kaira, K.; Murakami, H. Efficacy of gefitinib for non-adenocarcinoma non-small-cell lung cancer patients harboring epidermal growth factor receptor mutations: A pooled analysis of published reports. Cancer Sci. 2011, 102, 1032-1037. [CrossRef] [PubMed]

377. Harandi, A.; Zaidi, A.S.; Stocker, A.M.; Laber, D.A. Clinical efficacy and toxicity of anti-EGFR therapy in common cancers. J. Oncol. 2009. [CrossRef] [PubMed]

378. Lynch, T.J.; Bell, D.W.; Sordella, R.; Gurubhagavatula, S.; Okimoto, R.A.; Brannigan, B.W.; Harris, P.L.; Haserlat, S.M.; Supko, J.G.; Haluska, F.G.; et al. Activating Mutations in the Epidermal Growth Factor Receptor Underlying Responsiveness of Non-Small-Cell Lung Cancer to Gefitinib. N. Engl. J. Med. 2004, 350, 2129-2139. [CrossRef] [PubMed]

379. Bertotti, A.; Papp, E.; Jones, S.; Adleff, V.; Anagnostou, V.; Lupo, B.; Sausen, M.; Phallen, J.; Hruban, C.A.; Tokheim, C.; et al. The genomic landscape of response to EGFR blockade in colorectal cancer. Nature 2015, 526, 263-267. [CrossRef] [PubMed]

380. Krasinskas, A.M. EGFR Signaling in Colorectal Carcinoma. Pathol. Res. Int. 2011, 2011, 932932. [CrossRef] [PubMed]

381. Chung, K.Y.; Shia, J.; Kemeny, N.E.; Shah, M.; Schwartz, G.K.; Tse, A.; Hamilton, A.; Pan, D.; Schrag, D.; Schwartz, L.; et al. Cetuximab shows activity in colorectal cancer patients with tumors that do not express the epidermal growth factor receptor by immunohistochemistry. J. Clin. Oncol. 2005, 23, 1803-1810. [CrossRef] [PubMed]

382. Cunningham, D.; Humblet, Y.; Siena, S.; Khayat, D.; Bleiberg, H.; Santoro, A.; Bets, D.; Mueser, M.; Harstrick, A.; Verslype, C.; et al. Cetuximab monotherapy and cetuximab plus irinotecan in irinotecan-refractory metastatic colorectal cancer. N. Engl. J. Med. 2004, 351, 337-345. [CrossRef] [PubMed]

383. Laurent-Puig, P.; Cayre, A.; Manceau, G.; Buc, E.; Bachet, J.B.; Lecomte, T.; Rougier, P.; Lievre, A.; Landi, B.; Boige, V.; et al. Analysis of PTEN, BRAF, and EGFR status in determining benefit from cetuximab therapy in wild-type KRAS metastatic colon cancer. J. Clin. Oncol. 2009, 27, 5924-5930. [CrossRef] [PubMed]

384. Cleary, J.M.; Reardon, D.A.; Azad, N.; Gandhi, L.; Shapiro, G.I.; Chaves, J.; Pedersen, M.; Ansell, P.; Ames, W.; Xiong, H.; et al. A phase 1 study of ABT-806 in subjects with advanced solid tumors. Investig. New Drugs 2015, 33, 671-678. [CrossRef] [PubMed] 
385. Benvenuti, S.; Sartore-bianchi, A.; Di Nicolantonio, F.; Zanon, C.; Moroni, M.; Veronese, S.; Siena, S.; Bardelli, A. Oncogenic Activation of the RAS / RAF Signaling Pathway Impairs the Response of Metastatic Colorectal Cancers to Anti-Epidermal Growth Factor Receptor Antibody Therapies. Cancer Res. 2007, 67, 2643-2648. [CrossRef] [PubMed]

386. Di Fiore, F.; Blanchard, F.; Charbonnier, F.; Le Pessot, F.; Lamy, A.; Galais, M.P.; Bastit, L.; Killian, A.; Sesboue, R.; Tuech, J.J.; et al. Clinical relevance of KRAS mutation detection in metastatic colorectal cancer treated by Cetuximab plus chemotherapy. Br. J. Cancer 2007, 96, 1166-1169. [CrossRef] [PubMed]

387. Lievre, A.; Bachet, J.-B.; Boige, V.; Cayre, A.; Le Corre, D.; Buc, E.; Ychou, M.; Bouche, O.; Landi, B.; Louvet, C.; et al. KRAS Mutations As an Independent Prognostic Factor in Patients With Advanced Colorectal Cancer Treated With Cetuximab. J. Clin. Oncol. 2008, 26, 374-379. [CrossRef] [PubMed]

388. De Roock, W.; Piessevaux, H.; De Schutter, J.; Janssens, M.; De Hertogh, G.; Personeni, N.; Biesmans, B.; Van Laethem, J.L.; Peeters, M.; Humblet, Y.; et al. KRAS wild-type state predicts survival and is associated to early radiological response in metastatic colorectal cancer treated with cetuximab. Ann. Oncol. 2008, 19, 508-515. [CrossRef] [PubMed]

389. Cripps, C.; Gill, S.; Ahmed, S.; Colwell, B.; Dowden, S.; Kennecke, H.; Maroun, J.; Samson, B.; Thirlwell, M.; Wong, R. Consensus recommendations for the use of anti-egfr therapies in metastatic colorectal cancer. Curr. Oncol. 2010, 17, 39-45. [PubMed]

390. Sorich, M.J.; Wiese, M.D.; Rowland, A.; Kichenadasse, G.; McKinnon, R.A.; Karapetis, C.S. Extended RAS mutations and anti-EGFR monoclonal antibody survival benefit in metastatic colorectal cancer: A meta-analysis of randomized controlled trials. Ann. Oncol. 2015, 26, 13-21. [CrossRef] [PubMed]

391. Lovly, C.L.; Horn, G.; Oxnard, W.P. EGFR c.2369C>T (T790M) Mutation in Non-Small Cell Lung Cancer. My Cancer Genome. Available online: Https//www.mycancergenome.org/content/disease/lung-cancer/ egfr/4/ (accessed on 15 October 2015).

392. Zhang, Z.; Lee, J.C.; Lin, L.; Olivas, V.; Au, V.; LaFramboise, T.; Abdel-Rahman, M.; Wang, X.; Levine, A.D.; Rho, J.K.; et al. Activation of the AXL kinase causes resistance to EGFR-targeted therapy in lung cancer. Nat. Genet. 2012, 44, 852-860. [CrossRef] [PubMed]

393. Yauch, R.L.; Januario, T.; Eberhard, D.A.; Cavet, G.; Zhu, W.; Fu, L.; Pham, T.Q.; Soriano, R.; Stinson, J.; Seshagiri, S.; et al. Epithelial versus mesenchymal phenotype determines in vitro sensitivity and predicts clinical activity of erlotinib in lung cancer patients. Clin. Cancer Res. 2005, 11, 8686-8698. [CrossRef] [PubMed]

394. Uramoto, H.; Iwata, T.; Onitsuka, T.; Shimokawa, H.; Hanagiri, T.; Oyama, T. Epithelial-mesenchymal transition in EGFR-TKI acquired resistant lung adenocarcinoma. Anticancer Res. 2010, 30, 2513-2517.

395. Suda, K.; Tomizawa, K.; Fujii, M.; Murakami, H.; Osada, H.; Maehara, Y.; Yatabe, Y.; Sekido, Y.M.T. Epithelial to mesenchymal transition in an epidermal growth factor receptor-mutant lung cancer cell line with acquired resistance to erlotinib. J. Thorac. Oncol. 2011, 7, 1152-1161. [CrossRef] [PubMed]

396. Jakobsen, K.R.; Demuth, C.; Sorensen, B.S.; Nielsen, A.L. The role of epithelial to mesenchymal transition in resistance to epidermal growth factor receptor tyrosine kinase inhibitors in non-small cell lung cancer. Transl. Lung Cancer Res. 2016, 5, 172-182. [CrossRef] [PubMed]

397. Peeters, M.; Price, T.J.; Cervantes, A.; Sobrero, A.F.; Ducreux, M.; Hotko, Y.; André, T.; Chan, E.; Lordick, F.; Punt, C.J.A.; et al. Randomized phase III study of panitumumab with fluorouracil, leucovorin, and irinotecan (FOLFIRI) compared with FOLFIRI alone as second-line treatment in patients with metastatic colorectal cancer. J. Clin. Oncol. 2010, 28, 4706-4713. [CrossRef] [PubMed]

398. Mitchell, E.P.; Lacouture, M.; Shearer, H.; Iannotti, N.; Piperdi, B.; Pillai, M.; Xu, F.; Yassine, M. Final STEPP results of prophylacatic versus reactive skin toxicity (ST) treatment (tx) for panitumumab (pmab)-related ST in patients (pts) with metastatic colorectal cancer (mCRC). J. Clin. Oncol. 2009, 27, CRA4027. [CrossRef]

399. Park, K.; Tan, E.H.; O’Byrne, K.; Zhang, L.; Boyer, M.; Mok, T.; Hirsh, V.; Yang, J.C.H.; Lee, K.H.; Lu, S.; et al. Afatinib versus gefitinib as first-line treatment of patients with EGFR mutation-positive non-small-cell lung cancer (LUX-Lung 7): A phase 2B, open-label, randomised controlled trial. Lancet Oncol. 2016, 17, 577-589. [CrossRef]

400. Huillard, O.; Bakalian, S.; Levy, C.; Desjardins, L.; Lumbroso-Le Rouic, L.; Pop, S.; Sablin, M.P.; Le Tourneau, C. Ocular adverse events of molecularly targeted agents approved in solid tumours: A systematic review. Eur. J. Cancer 2014, 50, 638-648. [CrossRef] [PubMed] 
401. Johnson, K.S.; Levin, F.; Chu, D.S. Persistent corneal epithelial defect associated with erlotinib treatment. Cornea 2009, 28, 706-707. [CrossRef] [PubMed]

402. Carrasco-García, E.; Saceda, M.; Grasso, S.; Rocamora-Reverte, L.; Conde, M.; Gómez-Martínez, Á.; García-Morales, P.; Ferragut, J.A.; Martínez-Lacaci, I. Small tyrosine kinase inhibitors interrupt EGFR signaling by interacting with erbB3 and erbB4 in glioblastoma cell lines. Exp. Cell Res. 2011, 317, 1476-1489. [CrossRef] [PubMed]

403. Zhu, X.F.; Liu, Z.C.; Xie, B.F.; Li, Z.M.; Feng, G.K.; Yang, D.; Zeng, Y.X. EGFR tyrosine kinase inhibitor AG1478 inhibits cell proliferation and arrests cell cycle in nasopharyngeal carcinoma cells. Cancer Lett. 2001, 169, 27-32. [CrossRef]

404. Giocanti, N.; Hennequin, C.; Rouillard, D.; Defrance, R.; Favaudon, V. Additive interaction of gefitinib ('Iressa', ZD1839) and ionising radiation in human tumour cells in vitro. Br. J. Cancer 2004, 91, 2026-2033. [CrossRef] [PubMed]

405. Busse, D.; Doughty, R.S.; Ramsey, T.T.; Russell, W.E.; Price, J.O.; Flanagan, W.M.; Shawver, L.K.; Arteaga, C.L. Reversible G1 arrest induced by inhibition of the epidermal growth factor receptor tyrosine kinase requires up-regulation of p27(KIP1) independent of MAPK activity. J. Biol. Chem. 2000, 275, 6987-6995. [CrossRef] [PubMed]

406. Kiyota, A.; Shintani, S.; Mihara, M.; Nakahara, Y.; Ueyama, Y.; Matsumura, T.; Tachikawa, T.; Wong, D.T. Anti-epidermal growth factor receptor monoclonal antibody 225 upregulates p27(KIP1) and p15(INK4B) and induces G1 arrest in oral squamous carcinoma cell lines. Oncology 2002, 63, 92-98. [CrossRef] [PubMed]

407. Gonzales, A.J.; Fry, D.W. G1 cell cycle arrest due to the inhibition of erbB family receptor tyrosine kinases does not require the retinoblastoma protein. Exp. Cell Res. 2005, 303, 56-67. [CrossRef] [PubMed]

408. Huether, A.; Höpfner, M.; Sutter, A.P.; Schuppan, D.; Scherübl, H. Erlotinib induces cell cycle arrest and apoptosis in hepatocellular cancer cells and enhances chemosensitivity towards cytostatics. J. Hepatol. 2005, 43, 661-669. [CrossRef] [PubMed]

409. Markaverich, B.M.; Vijjeswarapu, M.; Shoulars, K.; Rodriguez, M. Luteolin and gefitinib regulation of EGF signaling pathway and cell cycle pathway genes in PC-3 human prostate cancer cells. J. Steroid Biochem. Mol. Biol. 2010, 122, 219-231. [CrossRef] [PubMed]

410. Ahn, S.H.; Jeong, E.H.; Lee, T.G.; Kim, S.Y.; Kim, H.R.; Kim, C.H. Gefitinib induces cytoplasmic translocation of the CDK inhibitor p27 and its binding to a cleaved intermediate of caspase 8 in non-small cell lung cancer cells. Cell. Oncol. 2014, 37, 377-386. [CrossRef] [PubMed]

411. Ma, L.; Yan, H.; Zhou, Q. AG1478 inhibits the migration and invasion of cisplatin-resistant human lung adenocarcinoma cells via the cell cycle regulation by matrix metalloproteinase-9. Oncol. Lett. 2014, 8, 921-927. [CrossRef]

412. Haraldsdottir, S.; Bekaii-Saab, T. Integrating anti-EGFR therapies in metastatic colorectal cancer. J. Gastrointest. Oncol. 2013, 4, 285-298. [CrossRef] [PubMed]

413. Li, H.; Zhou, S.; Li, X.; Wang, D.; Wang, Y.; Zhou, C. Schmid-Bindert, G. Gefitinib-resistance is related to BIM expression in non-small cell lung cancer cell lines. Cancer Biother. Radiopharm. 2013, 28, 115-123. [CrossRef] [PubMed]

414. Luo, M.; Fu, L.-W. Redundant kinase activation and resistance of EGFR-tyrosine kinase inhibitors. Am. J. Cancer Res. 2014, 4, 608-628. [PubMed]

415. Misale, S.; Arena, S.; Lamba, S.; Siravegna, G.; Lallo, A.; Hobor, S.; Russo, M.; Buscarino, M.; Lazzari, L.; Sartore-Bianchi, A.; et al. Blockade of EGFR and MEK intercepts heterogeneous mechanisms of acquired resistance to anti-EGFR therapies in colorectal cancer. Sci. Transl. Med. 2014, 6, 224ra26. [CrossRef] [PubMed]

416. Flaherty, K.T.; Robert, C.; Hersey, P.; Nathan, P.; Garbe, C.; Milhem, M.; Demidov, L.V.; Hassel, J.C.; Rutkowski, P.; Mohr, P.; et al. Improved Survival with MEK Inhibition in BRAF-Mutated Melanoma. N. Engl. J. Med. 2012, 367, 107-114. [CrossRef] [PubMed]

417. Flaherty, K.T.; Infante, J.R.; Daud, A.; Gonzalez, R.; Kefford, R.F.; Sosman, J.; Hamid, O.; Schuchter, L.; Cebon, J.; Ibrahim, N.; et al. Combined BRAF and MEK inhibition in melanoma with BRAF V600 mutations. N. Engl. J. Med. 2012, 367, 1694-1703. [CrossRef] [PubMed]

418. Huang, M.H.; Lee, J.H.; Chang, Y.J.; Tsai, H.H.; Lin, Y.L.; Lin, A.M.Y.; Yang, J.C.H. MEK inhibitors reverse resistance in epidermal growth factor receptor mutation lung cancer cells with acquired resistance to gefitinib. Mol. Oncol. 2013, 7, 112-120. [CrossRef] [PubMed] 
419. Turke, A.B.; Song, Y.; Costa, C.; Cook, R.; Arteaga, C.L.; Asara, J.M.; Engelman, J.A. MEK inhibition leads to $\mathrm{PI} 3 \mathrm{~K} / \mathrm{AKT}$ activation by relieving a negative feedback on ERBB receptors. Cancer Res. 2012, 72, 3228-3237. [CrossRef] [PubMed]

420. Rexer, B.N.; Ghosh, R.; Arteaga, C.L. Inhibition of PI3K and MEK: It is all about combinations and biomarkers. Clin. Cancer Res. 2009, 15, 4518-4520. [CrossRef] [PubMed]

421. Posch, C.; Moslehi, H.; Feeney, L.; Green, G.A.; Ebaee, A.; Feichtenschlager, V.; Chong, K.; Peng, L.; Dimon, M.T.; Phillips, T.; et al. Combined targeting of MEK and PI3K/mTOR effector pathways is necessary to effectively inhibit NRAS mutant melanoma in vitro and in vivo. Proc. Natl. Acad. Sci. USA 2013, 110, 4015-4020. [CrossRef] [PubMed]

422. Saini, K.S.; Loi, S.; de Azambuja, E.; Metzger-Filho, O.; Saini, M.L.; Ignatiadis, M.; Dancey, J.E.; Piccart-Gebhart, M.J. Targeting the PI3K/AKT/mTOR and Raf/MEK/ERK pathways in the treatment of breast cancer. Cancer Treat. Rev. 2013, 39, 935-946. [CrossRef] [PubMed]

423. Porta, C.; Paglino, C.; Mosca, A. Targeting PI3K/Akt/mTOR Signaling in Cancer. Front. Oncol. $2014,4,64$. [CrossRef] [PubMed]

424. Harrington, L.S.; Findlay, G.M.; Gray, A.; Tolkacheva, T.; Wigfield, S.; Rebholz, H.; Barnett, J.; Leslie, N.R.; Cheng, S.; Shepherd, P.R.; et al. The TSC1-2 tumor suppressor controls insulin-PI3K signaling via regulation of IRS proteins. J. Cell Biol. 2004, 166, 213-223. [CrossRef] [PubMed]

425. Chandarlapaty, S.; Sawai, A.; Scaltriti, M.; Rodrik-Outmezguine, V.; Grbovic-Huezo, O.; Serra, V.; Serra, V.; Majumder, P.K.; Baselga, J.; Rosen, N. AKT inhibition relieves feedback suppression of receptor tyrosine kinase expression and activity. Cancer Cell 2011, 19, 58-71. [CrossRef] [PubMed]

426. Chakrabarty, A.; Sanchez, V.; Kuba, M.G.; Rinehart, C.; Arteaga, C.L. Feedback upregulation of HER3 (ErbB3) expression and activity attenuates antitumor effect of PI3K inhibitors. Proc. Natl. Acad. Sci. USA 2012, 109, 2718-2723. [CrossRef] [PubMed]

427. Serra, V.; Scaltriti, M.; Prudkin, L.; Eichhorn, P.J.; Ibrahim, Y.H.; Chandarlapaty, S.; Markman, B.; Rodriguez, O.; Guzman, M.; Rodriguez, S.; et al. PI3K inhibition results in enhanced HER signaling and acquired ERK dependency in HER2-overexpressing breast cancer. Oncogene 2011, 30, 2547-2557. [CrossRef] [PubMed]

428. Rodrik-Outmezguine, V.S.; Chandarlapaty, S.; Pagano, N.C.; Poulikakos, P.I.; Scaltriti, M.; Moskatel, E.; Moskatel, E.; Baselga, J.; Guichard, S.; Rosen, N. mTOR kinase inhibition causes feedback-dependent biphasic regulation of AKT signaling. Cancer Discov. 2011, 1, 248-259. [CrossRef] [PubMed]

429. O’Reilly, K.E.; Rojo, F.; She, Q.-B.; Solit, D.; Mills, G.B.; Smith, D.; Lane, H.; Hofmann, F.; Hicklin, D.J.; Ludwig, D.L.; et al. mTOR inhibition induces upstream receptor tyrosine kinase signaling and activates Akt. Cancer Res. 2006, 66, 1500-1508. [CrossRef] [PubMed]

430. Amin, D.N.; Sergina, N.; Lim, L.; Goga, A.; Moasser, M.M. HER3 signalling is regulated through a multitude of redundant mechanisms in HER2-driven tumour cells. Biochem. J. 2012, 447, 417-425. [CrossRef] [PubMed]

431. Tao, J.J.; Castel, P.; Radosevic-Robin, N.; Elkabets, M.; Auricchio, N.; Aceto, N.; Weitsman, G.; Barber, P.; Vojnovic, B.; Ellis, H.; et al. Antagonism of EGFR and HER3 enhances the response to inhibitors of the PI3K-Akt pathway in triple-negative breast cancer. Sci. Signal. 2014, 7, ra29. [CrossRef] [PubMed]

432. Garrett, J.T.; Sutton, C.R.; Kurupi, R.; Bialucha, C.U.; Ettenberg, S.A.; Collins, S.D.; Sheng, Q.; Wallweber, J.; Defazio-Eli, L.; Arteaga, C.L. Combination of antibody that inhibits ligand-independent HER3 dimerization and a p110?? inhibitor potently blocks pi3k signaling and growth of HER2+ breast cancers. Cancer Res. 2013, 73, 6013-6023. [CrossRef] [PubMed]

433. Guertin, D.A.; Sabatini, D.M. Defining the Role of mTOR in Cancer. Cancer Cell 2007, 12, 9-22. [CrossRef] [PubMed]

434. Dang, C.V. MYC on the path to cancer. Cell 2012, 149, 22-35. [CrossRef] [PubMed]

435. Chen, S.; Rehman, S.K.; Zhang, W.; Wen, A.; Yao, L.; Zhang, J. Autophagy is a therapeutic target in anticancer drug resistance. Biochim. Biophys. Acta 2010, 1806, 220-229. [CrossRef] [PubMed]

436. Zhou, J.; Wu, Z.; Wong, G.; Pectasides, E.; Nagaraja, A.; Stachler, M.; Zhang, H.; Chen, T.; Liu, D. CDK4/6 or MAPK blockade enhances efficacy of EGFR inhibition in oesophageal squamous cell carcinoma. Nat. Commun. 2017, 8, 13897. [CrossRef] [PubMed]

437. Jones, S.M.; Kazlauskas, A. Growth-factor-dependent mitogenesis requires two distinct phases of signalling. Nat. Cell Biol. 2001, 3, 165-172. [CrossRef] [PubMed] 
438. Pennock, S.; Wang, Z.X. Stimulation of cell proliferation by endosomal epidermal growth factor receptor as revealed through two distinct phases of signaling. Mol. Cell. Biol. 2003, 23, 5803-5815. [CrossRef] [PubMed]

439. Blagosklonny, M.V.; Pardee, A.B. The restriction point of the cell cycle. Cell Cycle 2002, 1, 103-110. [CrossRef] [PubMed]

440. Kobayashi, S.; Shimamura, T.; Monti, S.; Steidl, U.; Hetherington, C.J.; Lowell, A.M.; Golub, T.; Meyerson, M.; Tenen, D.G.; Shapiro, G.L.; et al. Transcriptional profiling identifies Cyclin D1 as a critical downstream effector of mutant epidermal growth factor receptor signaling. Cancer Res. 2006, 66, 11389-11398. [CrossRef] [PubMed]

441. Reissmann, P.T.; Koga, H.; Figlin, R.A.; Holmes, E.C.; Slamon, D.J. Amplification and overexpression of the Cyclin D1 and epidermal growth factor receptor genes in non-small-cell lung cancer. Lung Cancer Study Group. J. Cancer Res. Clin. Oncol. 1999, 125, 61-70. [CrossRef] [PubMed]

442. McIntosh, G.G.; Anderson, J.J.; Milton, I.; Steward, M.; Parr, A.H.; Thomas, M.D.; Henry, J.A.; Angus, B.; Lennard, T.W.; Horne, C.H. Determination of the prognostic value of Cyclin D1 overexpression in breast cancer. Oncogene 1995, 11, 885-891. [PubMed]

443. Perry, J.E.; Grossmann, M.E.; Tindall, D.J. Epidermal growth factor induces Cyclin D1 in a human prostate cancer cell line. Prostate 1998, 35, 117-124. [CrossRef]

444. Narayanan, R.; Kim, H.N.; Narayanan, N.K.; Nargi, D.; Narayanan, B.A. Epidermal growth factor-stimulated human cervical cancer cell growth is associated with EGFR and Cyclin D1 activation, independent of COX-2 expression levels. Int. J. Oncol. 2012, 40, 13-20. [CrossRef] [PubMed]

445. Chen, S.J.; Luan, J.; Zhang, H.S.; Ruan, C.P.; Xu, X.Y.; Li, Q.Q.; Wang, N.H. EGFR-mediated G1/S transition contributes to the multidrug resistance in breast cancer cells. Mol. Biol. Rep. 2012, 39, 5465-5471. [CrossRef] [PubMed]

446. Cobrinik, D. Pocket proteins and cell cycle control. Oncogene 2005, 24, 2796-2809. [CrossRef] [PubMed]

447. Rubin, S.M. Deciphering the retinoblastoma protein phosphorylation code. Trends Biochem. Sci. 2013, 38, 12-19. [CrossRef] [PubMed]

448. Hatakeyama, M.; Brill, J.A.; Fink, G.R.; Weinberg, R.A. Collaboration of G1 cyclins in the functional inactivation of the retinoblastoma protein. Genes Dev. 1994, 8, 1759-1771. [CrossRef] [PubMed]

449. Yamamoto, T.; Ebisuya, M.; Ashida, F.; Okamoto, K.; Yonehara, S.; Nishida, E. Continuous ERK Activation Downregulates Antiproliferative Genes throughout G1 Phase to Allow Cell-Cycle Progression. Curr. Biol. 2006, 16, 1171-1182. [CrossRef] [PubMed]

450. Hu, Q.; Klippel, A.; Muslin, A.J.; Fantl, W.J.; Williams, L.T.; Anthony, J.; Wendy, J.; Lewis, T.; $\mathrm{Hu}$, Q.; Klippel, A.; et al. Ras-dependent induction of cellular responses by constitutively active phosphatidylinositol-3 kinase. Science 1995, 268, 100-102. [CrossRef] [PubMed]

451. Ghosh Choudhury, G.; Kim, Y.S.; Simon, M.; Wozney, J.; Harris, S.; Ghosh-Choudhury, N.; Abboud, H.E.; Ghosh Choundhury, G.; Ghosh-Choundhury, N. Bone morphogenetic protein 2 inhibits platelet-derived growth factor-induced $c$-fos gene transcription and DNA synthesis in mesangial cells. Involvement of mitogen-activated protein kinase. J. Biol. Chem. 1999, 274, 10897-10902. [CrossRef] [PubMed]

452. Schmidt, M.; Fernandez de Mattos, S.; van der Horst, A.; Klompmaker, R.; Kops, G.J.P.L.; Lam, E.W.-F.; Burgering, B.M.T.; Medema, R.H. Cell cycle inhibition by FoxO forkhead transcription factors involves downregulation of cyclin D. Mol. Cell. Biol. 2002, 22, 7842-7852. [CrossRef] [PubMed]

453. Torii, S.; Yamamoto, T.; Tsuchiya, Y.; Nishida, E. ERK MAP kinase in G1 cell cycle progression and cancer. Cancer Sci. 2006, 97, 697-702. [CrossRef] [PubMed]

454. Diehl, J.A.; Cheng, M.; Roussel, M.F.; Sherr, C.J. Glycogen synthase kinase-3beta regulates Cyclin D1 proteolysis and subcellular localization. Genes Dev. 1998, 12, 3499-3511. [CrossRef] [PubMed]

455. Welcker, M.; Singer, J.; Loeb, K.R.; Grim, J.; Bloecher, A.; Gurien-West, M.; Clurman, B.E.; Roberts, J.M. Multisite phosphorylation by Cdk2 and GSK3 controls cyclin E degradation. Mol. Cell 2003, 12, 381-392. [CrossRef]

456. Tullai, J.W.; Graham, J.R.; Cooper, G.M. A GSK-3-mediated transcriptional network maintains repression of immediate early genes in quiescent cells. Cell Cycle 2011, 10, 3072-3077. [CrossRef] [PubMed]

457. Sutherland, C.; Leighton, I.A.; Cohen, P. Inactivation of glycogen synthase kinase-3fl by phosphorylation: New kinase connections in insulin and growth-factor signalling. Biochem. J. 1993, 296, 15-19. [CrossRef] [PubMed] 
458. Stambolic, V.; Woodgett, J.R. Mitogen inactivation of glycogen synthase kinase-3 beta in intact cells via serine 9 phosphorylation. Biochem. J. 1994, 303 (Pt 3), 701-704. [CrossRef] [PubMed]

459. Waskiewicz, A.J.; Flynn, A.; Proud, C.G.; Cooper, J.A. Mitogen-activated protein kinases activate the serine/threonine kinases Mnk1 and Mnk2. EMBO J. 1997, 16, 1909-1920. [CrossRef] [PubMed]

460. Wang, X.; Flynn, A.; Waskiewicz, A.J.; Webb, B.L.J.; Vries, R.G.; Baines, I.A.; Cooper, J.A.; Proud, C.G. The phosphorylation of eukaryotic initiation factor eIF4E in response to phorbol esters, cell stresses, and cytokines is mediated by distinct MAP kinase pathways. J. Biol. Chem. 1998, 273, 9373-9377. [CrossRef] [PubMed]

461. Fry, D.W.; Harvey, P.J.; Keller, P.R.; Elliott, W.L.; Meade, M.; Trachet, E.; Albassam, M.; Zheng, X.; Leopold, W.R.; Pryer, N.K.; et al. Specific inhibition of cyclin-dependent kinase 4/6 by PD 0332991 and associated antitumor activity in human tumor xenografts. Mol. Cancer Ther. 2004, 3, 1427-1438. [PubMed]

462. Toogood, P.L.; Harvey, P.J.; Repine, J.T.; Sheehan, D.J.; VanderWel, S.N.; Zhou, H.; Keller, P.R.; McNamara, D.J.; Sherry, D.; Zhu, T.; et al. Discovery of a potent and selective inhibitor of cyclin-dependent kinase 4/6. J. Med. Chem. 2005, 48, 2388-2406. [CrossRef] [PubMed]

463. Asghar, U.; Witkiewicz, A.K.; Turner, N.C.; Knudsen, E.S. The history and future of targeting cyclin-dependent kinases in cancer therapy. Nat. Rev. Drug Discov. 2015, 14, 130-146. [CrossRef] [PubMed]

464. An, H.X.; Beckmann, M.W.; Reifenberger, G.; Bender, H.G.; Niederacher, D. Gene amplification and overexpression of CDK4 in sporadic breast carcinomas is associated with high tumor cell proliferation. Am. J. Pathol. 1999, 154, 113-118. [CrossRef]

465. Mayer, E.L. Targeting Breast Cancer with CDK Inhibitors. Curr. Oncol. Rep. 2015, 17, 443. [CrossRef] [PubMed]

466. Toyoshima, H.; Hunter, T. p27, A novel inhibitor of G1 cyclin-Cdk protein kinase activity, is related to p21. Cell 1994, 78, 67-74. [CrossRef]

467. Cheng, M.; Sexl, V.; Sherr, C.J.; Roussel, M.F. Assembly of cyclin D-dependent kinase and titration of p27 ${ }^{\mathrm{KIP} 1}$ regulated by mitogen-activated protein kinase kinase (MEK1). Proc. Natl. Acad. Sci. USA 1998, 95, 1091-1096. [CrossRef] [PubMed]

468. Katayose, Y.; Kim, M.; Rakkar, A.N.S.; Li, Z.; Cowan, K.H.; Seth, P. Promoting apoptosis: A novel activity associated with the cyclin- dependent kinase inhibitor p27. Cancer Res. 1997, 57, 5441-5445. [PubMed]

469. Nickeleit, I.; Zender, S.; Kossatz, U.; Malek, N.P. P27 ${ }^{\text {KIP1 }}$ : A Target for Tumor Therapies? Cell Div. $2007,2,13$. [CrossRef] [PubMed]

470. Yang, F.; Meng, Y.; Li, J.; Zhang, D.; Yu, Y.; Lepor, H.; Wu, X.R.; Huang, H. p27 ${ }^{\mathrm{KIP} 1}$ down-regulates egfr expression via inhibition of JNK/C-JUN transactivation: A novel function of $\mathrm{p}^{2} 7^{\mathrm{KIP} 1}$ in tumor suppression deficient in metastatic bladder cancer cells. J. Urol. 2013, 189, e463. [CrossRef]

471. Fang, Y.; Wang, Y.; Wang, Y.; Meng, Y.; Zhu, J.; Jin, H.; Li, J.; Zhang, D.; Yu, Y.; Wu, X.-R.; et al. A new tumour suppression mechanism by p27Kip1: EGFR down-regulation mediated by JNK/c-Jun pathway inhibition. Biochem. J. 2014, 463, 383-392. [CrossRef] [PubMed]

472. Rivard, N.; Boucher, M.-J.; Asselin, C.; L'Allemain, G. MAP kinase cascade is required for p27 downregulation and S phase entry in fibroblasts and epithelial cells. Am. J. Physiol. 1999, 277, C652-C664. [PubMed]

473. Delmas, C.; Manenti, S.; Boudjelal, A.; Peyssonnaux, C.; Eychène, A.; Darbon, J.M. The p42/p44 mitogen-activated protein kinase activation triggers p27 ${ }^{\mathrm{KIP} 1}$ degradation independently of CDK2/cyclin E in NIH 3 T3 cells. J. Biol. Chem. 2001, 276, 34958-34965. [CrossRef] [PubMed]

474. Kortylewski, M.; Heinrich, P.C.; Kauffmann, M.E.; Bohm, M.; Mackiewicz, A.; Behrmann, I. Mitogen-activated protein kinases control p27/Kip1 expression and growth of human melanoma cells. Biochem. J. 2001, 357, 297-303. [CrossRef] [PubMed]

475. Kawada, M.; Yamagoe, S.; Murakami, Y.; Suzuki, K.; Mizuno, S.; Uehara, Y. Induction of p27KIP1 degradation and anchorage independence by Ras through the MAP kinase signaling pathway. Oncogene 1997, 15, 629-637. [CrossRef] [PubMed]

476. Wu, S.; Cetinkaya, C.; Munoz-Alonso, M.J.; von der Lehr, N.; Bahram, F.; Beuger, V.; Eilers, M.; Leon, J.; Larsson, L.-G. Myc represses differentiation-induced p21CIP1 expression via Miz-1-dependent interaction with the p21 core promoter. Oncogene 2003, 22, 351-360. [CrossRef] [PubMed]

477. Sahin, O.; Fröhlich, H.; Löbke, C.; Korf, U.; Burmester, S.; Majety, M.; Mattern, J.; Schupp, I.; Chaouiya, C.; Thieffry, D.; et al. Modeling ERBB receptor-regulated G1/S transition to find novel targets for de novo trastuzumab resistance. BMC Syst. Biol. 2009, 3, 1. [CrossRef] [PubMed] 
478. Liang, J.; Zubovitz, J.; Petrocelli, T.; Kotchetkov, R.; Connor, M.K.; Han, K.; Lee, J.-H.; Ciarallo, S.; Catzavelos, C.; Beniston, R.; et al. PKB/Akt phosphorylates p27, impairs nuclear import of p27 and opposes p27-mediated G1 arrest. Nat. Med. 2002, 8, 1153-1160. [CrossRef] [PubMed]

479. Katayama, K.; Fujita, N.; Tsuruo, T. Akt/protein kinase B-dependent phosphorylation and inactivation of WEE1Hu promote cell cycle progression at G2/M transition. Mol. Cell. Biol. 2005, 25, 5725-5737. [CrossRef] [PubMed]

480. Medema, R.H.; Kops, G.J.; Bos, J.L.; Burgering, B.M. AFX-like Forkhead transcription factors mediate cell-cycle regulation by Ras and PKB through p27kip1. Nature 2000, 404, 782-787. [CrossRef] [PubMed]

481. Dijkers, P.F.; Medema, R.H.; Pals, C.; Banerji, L.; Thomas, N.S.; Lam, E.W.; Burgering, B.M.; Raaijmakers, J.A.; Lammers, J.W.; Koenderman, L.; et al. Forkhead transcription factor FKHR-L1 modulates cytokine-dependent transcriptional regulation of p27(KIP1). Mol. Cell. Biol. 2000, 20, 9138-9148. [CrossRef] [PubMed]

482. Wang, Q.; Zhou, Y.; Wang, X.; Evers, B.M. p27 ${ }^{\mathrm{KIP} 1}$ nuclear localization and cyclin-dependent kinase inhibitory activity are regulated by glycogen synthase kinase-3 in human colon cancer cells. Cell Death Differ. 2008, 15, 908-919. [CrossRef] [PubMed]

483. Goh, L.K.; Huang, F.; Kim, W.; Gygi, S.; Sorkin, A. Multiple mechanisms collectively regulate clathrin-mediated endocytosis of the epidermal growth factor receptor. J. Cell Biol. 2010, 189, 871-883. [CrossRef] [PubMed]

484. Wang, Q.; Chen, X.; Wang, Z. Dimerization drives EGF receptor endocytosis through two sets of compatible endocytic codes. J. Cell Sci. 2015, 128, 935-950. [CrossRef] [PubMed]

485. Levkowitz, G.; Waterman, H.; Zamir, E.; Kam, Z.; Oved, S.; Langdon, W.Y.; Beguinot, L.; Geiger, B.; Yarden, Y. c-Cb1/Sli-1 regulates endocytic sorting and ubiquitination of the epidermal growth factor receptor. Genes Dev. 1998, 12, 3663-3674. [CrossRef] [PubMed]

486. Sousa, L.P.; Lax, I.; Shen, H.; Ferguson, S.M.; De Camilli, P.; Schlessinger, J. Suppression of EGFR endocytosis by dynamin depletion reveals that EGFR signaling occurs primarily at the plasma membrane. Proc. Natl. Acad. Sci. USA 2012, 109, 4419-4424. [CrossRef] [PubMed]

487. Noh, T.; Kook, Y.H.; Park, C.; Youn, H.; Kim, H.; Oh, E.T.; Beguinot, L.; Geiger, B.; Yarden, Y. Block copolymer micelles conjugated with anti-EGFR antibody for targeted delivery of anticancer drug. J. Polym. Sci. Part A Polym. Chem. 2008, 46, 7321-7331. [CrossRef]

488. Maya, S.; Sarmento, B.; Lakshmanan, V.K.; Menon, D.; Jayakumar, R. Actively targeted cetuximab conjugated gamma-poly(glutamic acid)-docetaxel nanomedicines for epidermal growth factor receptor over expressing colon cancer cells. J. Biomed. Nanotechnol. 2014, 10, 1416-1428. [CrossRef] [PubMed]

489. Wee, P.; Shi, H.; Jiang, J.; Wang, Y.; Wang, Z. EGF stimulates the activation of EGF receptors and the selective activation of major signaling pathways during mitosis. Cell Signal. 2015, 27, 638-651. [CrossRef] [PubMed]

490. Liu, L.; Shi, H.; Chen, X.; Wang, Z. Regulation of EGF-stimulated EGF receptor endocytosis during M phase. Traffic 2011, 12, 201-217. [CrossRef] [PubMed]

491. Dangi, S.; Shapiro, P. Cdc2-mediated inhibition of epidermal growth factor activation of the extracellular signal-regulated kinase pathway during mitosis. J. Biol. Chem. 2005, 280, 24524-24531. [CrossRef] [PubMed]

492. Kiyokawa, N. Mitosis-specific Negative Regulation of Epidermal Growth Factor Receptor, Triggered by a Decrease in Ligand Binding and Dimerization, Can Be Overcome by Overexpression of Receptor. J. Biol. Chem. 1997, 272, 18656-18665. [CrossRef] [PubMed]

(C) 2017 by the authors. Licensee MDPI, Basel, Switzerland. This article is an open access article distributed under the terms and conditions of the Creative Commons Attribution (CC BY) license (http:/ / creativecommons.org/licenses/by/4.0/). 